\author{
UNIVERSIDADE DE SÃO PAULO \\ INSTITUTO DE FÍSICA - FACULDADE DE EDUCAÇÃO
}

\title{
O ENSINO DO CONCEITO DE TEMPO: CONTRIBUIÇÕES HISTÓRICAS E EPISTEMOLÓGICAS
}

\author{
ANDRÉ FERRER PINTO MARTINS
}

Banca Examinadora:

Prof. Dr. JOÃO ZANETIC (Orientador)

Prof $^{a}$. Dr ${ }^{\mathrm{a}}$. HERCÍLIA TAVARES DE MIRANDA

Prof. Dr. MANOEL ROBERTO ROBILOTTA

Dissertação apresentada ao Instituto de Física e à Faculdade de Educação como parte dos requisitos necessários à obtenção do título de Mestre em Ensino de Ciências - Modalidade Física.

São Paulo

1998 


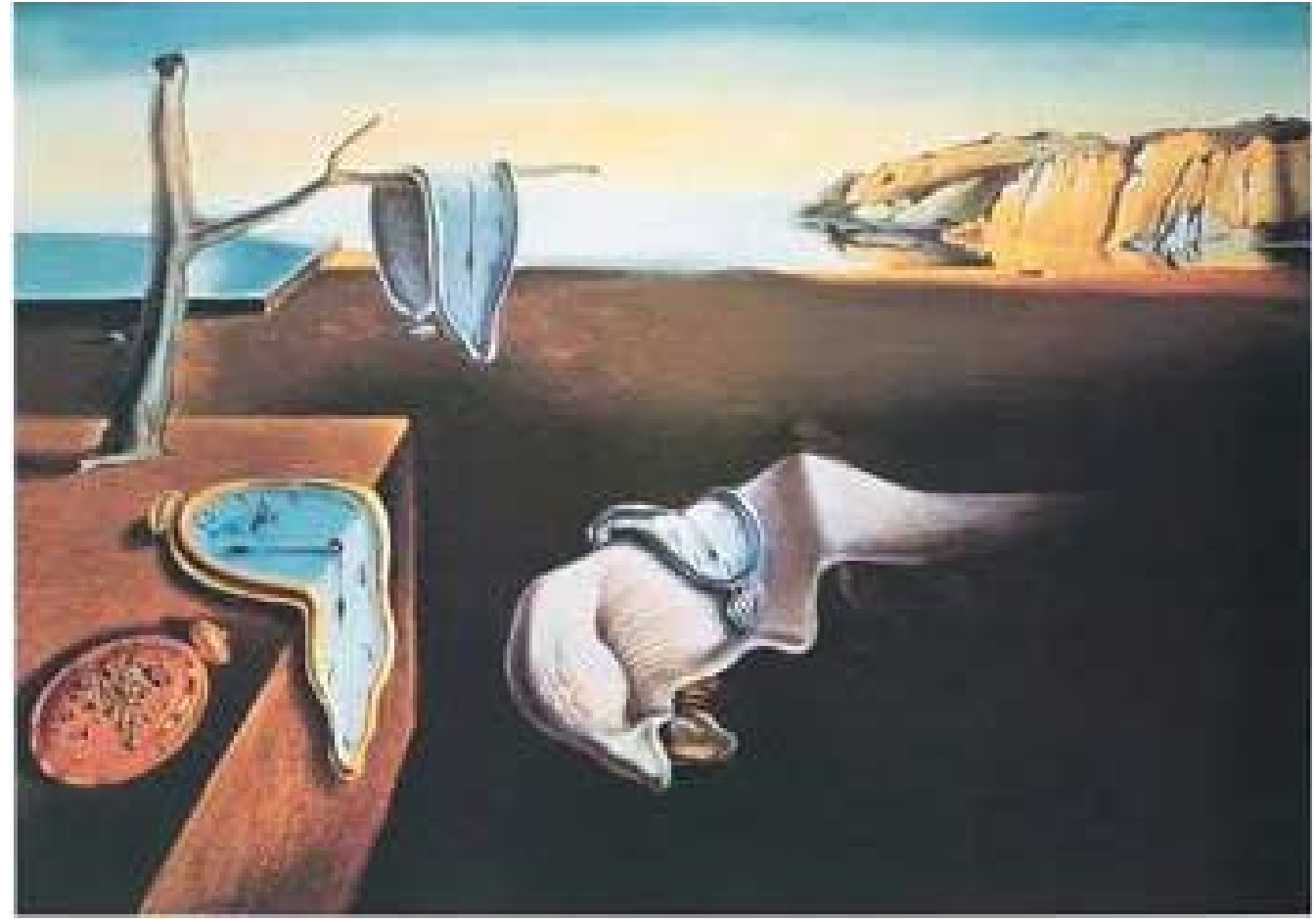

A Persistência da Memória (ou: Os Relógios Moles; ou: As Horas Derretidas), 1931.

Salvador Dalí 


\section{RESUMO}

Tendo como ponto de partida o que poderia ser chamado de "epistemologias históricas da ciência", delineia-se uma concepção de ciência que se insere, mais amplamente, numa teoria dialética do conhecimento, em contraposição a uma visão metafísica. Busca-se em seguida explicitar a relação entre tais epistemologias e a prática pedagógica, emergindo disso nossa opção por uma educação dialógica e libertadora, da qual se depreende, entre outras coisas, a relevância da história da ciência sob diversos aspectos. Fundamentado nessa perspectiva, aborda-se o conceito de tempo, de extrema importância no âmbito da física, resultando na construção de um texto, destinado preferencialmente a professores de ciências, a partir da re-leitura de uma pesquisa histórica sobre esse tema. 


\begin{abstract}
Starting from what may be called "historical epistemologies of science", we elaborate a conception of science which may be classified in a general way as a dialectical theory of knowledge, as opposed to a metaphysical point of view. We then explore the relation between such epistemologies and pedagogic practice, from which emerges our option for a dialogical and liberative education, which in turn emphasizes, beside other things, the relevance of history of science under various aspects. Bared on such perspective, we study the concept of time, which is extremely important in physics, and as a result, after re-reading a historical research on this theme, construct a text aimed primarily at science teachers.
\end{abstract}




\section{AGRADECIMENTOS}

À CAPES, pelo apoio financeiro.

Às colegas Nara e Helena, interessadas como eu nos "mistérios" do tempo, e que também buscam o prazer de aprender física.

Ao "pessoal do corredor", pelo ambiente descontraído e alegre, pelos "almoços e cafés", e pelos bate-papos intermináveis.... Em especial à Kátia, Andréa, Bia, Serginho, Jô, Roberto, Cris, Tanimara, Ferdinand, Eddie, Inês Ota, Beth Barolli, Renato e Beth. Em particular ao Fernando, pelo companheirismo, apoio "técnico e logístico", e pelos "debates acadêmicos".

À D. Úrsula, que descobriu o seu lugar, e ao Sr. Marcos, porque "pra ficar bom mesmo, demora".

Ao Osvaldo, que além de ler e dar sugestões numa parte do texto, indicou-me inúmeras referências importantíssimas.

Ao Moacyr e à Hercília, pelos mais altos devaneios, sempre com os pés no chão.

À Maria Regina e ao Mané, que contribuíram decisivamente para uma reorientação do trabalho na aula de qualificação.

Ao Justo, pelas “viagens" de longos anos....

Ao João, que me orientou antes mesmo do mestrado começar, pela atuação política, clareza de idéias e liberdade de pensamento.

À Renata, que compartilhou comigo as euforias e tensões durante todo o processo, e com quem compartilho, mais do que palavras, o silêncio.

À minha família. E aos meus pais, pelo tempo da vida. 
Esta dissertação é dedicada ao educador (e educando!)

Paulo Freire, falecido recentemente, cuja obra ainda não foi reconhecida devidamente por nosso país. 


\section{ÍNDICE}

INTRODUÇÃO (EM PRIMEIRA PESSOA) .................................................... 8

I. CONSIDERAÇÕES EPISTEMOLÓGICAS................................................... 12

I.1. UMA CONCEPÇÃO DE CIÊNCIA ?....................................................... 13

I.2. O PROGRESSO EM CIÊNCIA................................................................. 20

I.3. ALGUMAS RELAÇÕES POSSÍVEIS ENTRE AS EPISTEMOLOGIAS DE

KUHN E BACHELARD..................................................................... 30

I.4. PODERIA HAVER MELHORES MANEIRAS DE PROMOVER O

PROGRESSO CIENTÍFICO ?.................................................................... 36

I.5. ALGUMAS RELAÇÕES POSSÍVEIS ENTRE AS EPISTEMOLOGIAS DE

KUHN, BACHELARD E FEYERABEND................................................ 42

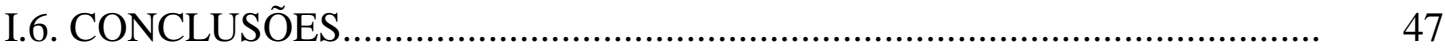

II. CONSIDERAÇÕES EDUCACIONAIS ........................................................... 52

II.1. UMA CONCEPÇÃO DE EDUCAÇÃO ?.................................................. 53

II.2. A HISTÓRIA DA CIÊNCIA E O ENSINO DE FÍSICA.............................. 65

II.3. A INTERDISCIPLINARIDADE ............................................................. 69

III. A HISTÓRIA DA CIÊNCIA E O CONCEITO DE TEMPO : UMA VISÃO

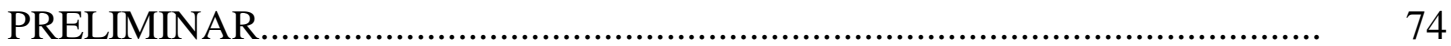

III.1. O TEMPO NA ANTIGÜIDADE ............................................................ 76

III.2. O TEMPO NO FIM DA ANTIGÜIDADE E NA IDADE MÉDIA............... 83

III.3. O TEMPO E O NASCIMENTO DA CIÊNCIA MODERNA...................... 88

III.4. O TEMPO NO SÉCULO XIX: A CONSERVAÇÃO DA ENERGIA E A

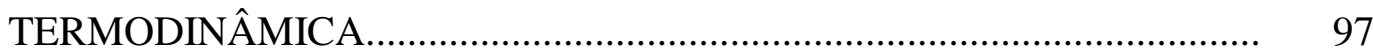

III.5. O TEMPO NO SÉCULO XX: A RELATIVIDADE, A MECÂNICA QUÂNTICA E A COSMOLOGIA....................................................... 102

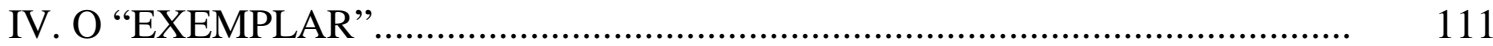

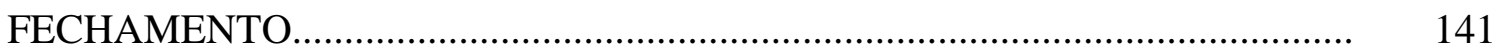

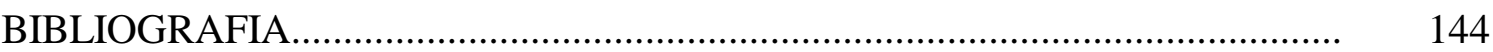


Mas já que se há de escrever, que ao menos não se esmaguem com palavras as entrelinhas.

Clarice Lispector (em "Para não esquecer”) 


\section{INTRODUÇÃO (EM PRIMEIRA PESSOA)}

Todo texto tem um contexto. A finalidade desta seção é justamente "contextualizar" um pouco esse trabalho. Do ponto de vista estritamente "acadêmico", talvez sejam essas linhas desnecessárias. Do ponto de vista "humano", não. Gostaria então de, o mais brevemente possível, apontar alguns fatores que me motivaram a elaborar esta dissertação.

Quando olho para o passado e procuro avaliar meu curso de "segundo grau", percebo o quanto ele foi "tradicional". Isso porque a escola enfatizava direta e exclusivamente os concursos vestibulares, oferecendo mais propriamente treinamento do que educação. Não se pode dizer, no entanto, que tal ensino não fosse "eficiente": ao final do terceiro ano, eu era capaz de realizar "simulados" e reconhecer, pelo enunciado das questões, a que exames elas tinham pertencido (Fuvest, Unicamp, Mauá, PUC etc), o que (pelo menos) acabou por tranqüilizar-me numa época em que boa parte dos estudantes encontra-se submetida a fortes tensões.

Paralelamente a isso, de algum modo, foi surgindo meu interesse pela física. Gostava muito de astronomia, e adquiri um pequeno telescópio refletor, de fabricação caseira, com o qual passei a observar o (quase invisível) céu paulistano. Atraía-me a idéia de que a luz das estrelas demorava anos, séculos, para chegar até nós. O convívio simultâneo, em meus olhos, de várias épocas diferentes, tornava presente o passado, como se o próprio tempo sofresse uma espécie de "vertigem", num universo interligado. Assistia aos filmes da série Cosmos na escola, que os projetava à tarde para os alunos do cursinho. E tive a sorte de encontrar ao menos um, dentre os diversos professores de física que tive, que discutia algo além da resolução de exercícios-padrão. Resolvi então cursar física, para poder ser astrônomo.

A universidade expandiu-me enormemente os horizontes, tanto no que se refere ao conhecimento científico, quanto à atuação política. Durante os dois primeiros anos, freqüentei diversas unidades do campus, assistindo a palestras, seminários e conferências acerca dos mais variados temas de diversas áreas.

$\mathrm{Na}$ "praça do relógio", aqui na USP, encontra-se a inscrição: "no universo da cultura o centro está em toda parte". Essa espécie de "homogeneidade e isotropia" do conhecimento, que representou meu ideal de universidade durante esse período, é 
entretanto propalada sob a égide de um relógio, que permanece ali para lembrar-nos que o tempo está passando....

Por outro lado, aumentava aos poucos minha decepção com as aulas no Instituto de Física, que em sua maioria eram desmotivadoras. Grande parte dos professores limitava-se a "transmitir" uma certa porção de um ou mais livros, complementando a exposição com listas de exercícios. Como o "conteúdo" a ser estudado é extremamente vasto, o que se "guarda" efetivamente de tudo isso? Mas, pior do que isso, era o pragmatismo e dogmatismo presentes nas aulas, geradores de um "clima" no qual tornava-se, cada vez mais difícil, levantar a mão e dizer: "não entendi”!

Não culpo muitos professores por esse tipo de "ensino". Afinal, não se exige do professor universitário uma capacitação nesse sentido. Ausente na formação dos "pesquisadores", a problemática da educação se lhes apresenta muitas vezes como um problema, que enfrentam repetindo as mesmas formas de ensinar de que foram "vítimas". O desconhecimento leva à repetição, à "transmissão" de conhecimentos que Paulo Freire caracteriza como "educação bancária”, como discutiremos em breve.

Se a universidade "expandia horizontes" por um lado, repetia por outro uma educação a-crítica, que eu já havia presenciado no "segundo grau". Entretanto, se a eficiência de tal ensino mostrara-se com o vestibular, agora inexistia uma semelhante "finalidade" que pudesse justificá-la. Necessitaria a formação de um cientista ser dessa maneira?

Como quase todos os meus colegas, pensei algumas vezes em desistir do curso. Num país onde milhões sequer sabem ler ou escrever, estar numa universidade parecia um luxo tão grande quanto desistir dela. Tal situação, acrescida à falta de perspectiva profissional, levou-me inicialmente à licenciatura, que passei a cursar em paralelo com o bacharelado. As novas disciplinas permitiram-me um diálogo maior, com os professores e com a física. Encontrei Paulo Freire, a história e a filosofia da ciência. A astronomia ficara para trás.

Depois de formado afastei-me por cerca de quatro anos da USP, lecionando em diversas escolas de "segundo grau" e num curso supletivo, o que me fez ver que os problemas educacionais são maiores na prática do que na teoria. Entretanto, o distanciamento da universidade trazia-me um certo sentimento de "estagnação", uma necessidade de estudar, de renovar-se. A pós-graduação representava, nesse momento, a 
possibilidade não apenas de retomar mais intensamente os estudos, mas também de promover um aprofundamento teórico a partir de uma prática de alguns poucos anos. Aprender física ainda poderia ser prazeiroso.

Durante o mestrado cursei diversas disciplinas, e pude perceber que também nesse nível repetem-se os problemas colocados acima quanto à graduação. Infelizmente, "autonomia" ainda é uma palavra mais presente nos discursos pedagógicos do que nas salas de aula. Por outro lado, as leituras realizadas em nosso grupo de estudos de história e filosofia da ciência, os seminários de ensino, e algumas disciplinas cursadas, foram de extrema valia para a elaboração desse trabalho, e vieram ao encontro de minhas expectativas. Num estranho processo, senti que é preciso des-aprender muita coisa, para poder aprender realmente. Acho que recuperei parte do prazer em estudar física.

O interesse pela questão do tempo certamente não é novo, embora tenha "consolidado-se" com a elaboração de uma monografia, há menos de dois anos. Pessoalmente, acredito que nossa sociedade atual, por motivos ligados à sua organização política e econômica, é escrava do tempo, em diversos sentidos. Mas é possível (e preciso) negar essa visão como única e definitiva para re-descobrir e $a d$ mirar esse conceito. De um lado, o tempo subjetivo, a percepção do tempo, a construção cognitiva dessa noção, as diferentes visões sociais e históricas a seu respeito, a memória, tudo isso é complexo e interessante, assim como, de outro, o tempo físico, seja ele da mecânica clássica, da relatividade, ou "retocado" pela termodinâmica ou pela cosmologia. Além disso, a problematização pedagógica desses conceitos ainda é um terreno não muito explorado.

Desvela-se assim (mas jamais inteiramente) o mistério do tempo que, como quase todos os "obscuros" conceitos da física, paradoxalmente "claros" à primeira vista, exerce o seu fascínio. A própria palavra que, isolada, leva quase que imediatamente à reflexão, é em si mesma uma metáfora da existência.

Muitas dessas entrelinhas estarão presentes na dissertação que segue. 


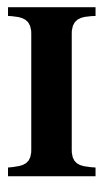

NATAL

Nasce um deus. Outros morrem. A Verdade Nem veio nem se foi: o Erro mudou.

Temos agora uma outra Eternidade,

E era sempre melhor o que passou.

Cega, a Ciência a inútil gleba lavra.

Louca, a Fé vive o sonho do seu culto.

Um novo deus é só uma palavra.

Não procures nem creias: tudo é oculto.

Fernando Pessoa (em "Mensagem”) 


\section{CONSIDERAÇÕES EPISTEMOLÓGICAS}

A ciência é uma atividade essencialmente conservadora. Não obstante, sofreu profundas e radicais transformações ao longo de sua história. Essas características da ciência seriam realmente paradoxais como parecem? Em que medida o desenvolvimento científico (e uma possível visão de "progresso") as pressupõe?

Nossa intenção aqui não poderia ser, obviamente, a de responder detalhadamente essas questões mas, antes de tudo, pretendemos delinear uma concepção de ciência a partir da análise de algumas respostas possíveis. Esse "exercício epistemológico" visa também "problematizar" certas visões sobre a ciência, explícita ou implicitamente presentes em textos didáticos e, portanto, nas salas de aula.

É claro que as afirmações colocadas inicialmente já seriam, em si, objeto de profunda reflexão. Sequer teriam sentido dentro de concepções epistemológicas outras. Não se trata, portanto, de "prová-las", mas de justificá-las e defendê-las à luz de uma concepção epistemológica que não se pretende única ou definitiva. É dentro dela que buscaremos, de início, as nossas respostas.

Em nosso caminho encontraremos abrigo em outras concepções epistemológicas que compartilham diversos e importantes elementos de análise com aquela da qual partiremos. Dentre eles, o referencial oferecido pela história da ciência parece-nos fundamental, permitindo-nos estabelecer importantes relações para esse trabalho.

\section{I.1. UMA CONCEPÇÃO DE CIÊNCIA ?}

(...) uma nova verdade científica não triunfa convencendo seus oponentes e fazendo com que vejam a luz, mas porque seus oponentes finalmente morrem e uma nova geração cresce familiarizada com ela.

Max Planck

Partiremos então do trabalho desenvolvido por Thomas S. Kuhn. Em seu ensaio intitulado A Estrutura das Revoluções Científicas, ele defende que o desenvolvimento da ciência dá-se de uma forma não cumulativa. Isso significa que o conhecimento 
científico não se assemelha à construção de um edifício onde, "tijolo por tijolo", o trabalho de uma geração é simplesmente acrescentado ao da anterior. O "desenho mágico" da ciência emerge de um processo onde há lugar para rupturas, crises e revoluções.

Para compreendermos como essa visão é possível, temos que voltar nossos olhos para o trabalho cotidiano e a educação dos cientistas. Esses, durante toda ou a maior parte de seu tempo, trabalham no que Kuhn denomina de "ciência normal", uma atividade que não visa produzir novidades inesperadas, mas "articular" o conjunto de teorias, modelos e representações compartilhados pelos cientistas, e que constituem sua particular "visão de mundo". Esse conjunto constitui uma grande parcela do que o autor chama de "paradigma", um conceito fundamental em seu trabalho, e estreitamente vinculado à ciência normal. É justamente a aceitação de um paradigma, por um determinado grupo de praticantes da ciência, que permite o desenvolvimento da ciência normal:

"Homens cuja pesquisa está baseada em paradigmas compartilhados estão
comprometidos com as mesmas regras e padrões para a prática científica. Esse
comprometimento e o consenso aparente que produz são pré-requisitos para a
ciência normal, isto é , para a gênese e a continuação de uma tradição de
pesquisa determinada.

O período anterior ao da aceitação de um paradigma por um grupo é denominado de fase "pré-paradigmática", na qual diversos candidatos a paradigma concorrem, buscando a adesão de subgrupos cada vez maiores. Kuhn busca, na história da ciência, exemplos que possam ilustrar esse período, como a óptica antes de Newton e a pesquisa elétrica na primeira metade do século XVIII. Em ambos os casos, diversas escolas com visões conflitantes procuravam enfatizar o conjunto de fenômenos que suas próprias teorias explicavam melhor. ${ }^{3}$ No entanto, é a firme adesão a um único paradigma que permite a "maturidade" de um campo de estudos. Durante esse processo, os demais candidatos a paradigma desaparecem:

"Quando, pela primeira vez no desenvolvimento de uma ciência da natureza, um indivíduo ou grupo produz uma síntese capaz de atrair a maioria dos praticantes de ciência da geração seguinte, as escolas mais antigas começam a desaparecer

\footnotetext{
${ }^{1}$ Apud KUHN, T. S. - A Estrutura das Revoluções Científicas, $2^{\mathrm{a}}$ edição, 1987, p. 191.

${ }^{2}$ KUHN, T. S. - Op. cit., p. 30-31.

${ }^{3}$ Ibid., p. 29-42.
} 
gradualmente. Seu desaparecimento é em parte causado pela conversão de seus adeptos ao novo paradigma. Mas sempre existem alguns que se aferram a uma ou outra das concepções mais qntigas; são simplesmente excluídos da profissão e seus trabalhos são ignorados. "4

O paradigma norteador do trabalho do cientista normal é, antes de tudo, uma promessa: sua articulação representará a atualização dessa promessa. E essa articulação dar-se-á tanto no nível teórico como experimental. A própria determinação de quais são os fenômenos passíveis de investigação (sendo, portanto, “científicos"), bem como a metodologia válida para a pesquisa, fazem parte desse amplo processo.

É durante o desenvolvimento da ciência normal que o conhecimento acerca do mundo aprofunda-se. Imersos em atividades cada vez mais esotéricas, os cientistas buscam no fundo resolver "quebra-cabeças" altamente complexos. Essa analogia sugerida por Kuhn procura reforçar o fato de que a ciência normal não produz necessariamente algo comum e corriqueiro, simplesmente porque atua a partir de um paradigma já estabelecido. Contudo, debruça-se sobre problemas que, a priori, acredita possuírem uma solução nos moldes definidos pelo paradigma vigente.

Como é possível então que uma atividade como a ciência normal gere novidades? Segundo Kuhn, a prática orientada por um paradigma produz, de tempos em tempos, "anomalias", que representam pontos onde a aplicação do paradigma apresentou problemas. As anomalias podem levar a descobertas e invenções que acabam por ser incorporadas ao paradigma:

"A descoberta começa com a consciência da anomalia, isto é, com o reconhecimento de que, de alguma maneira, a natureza violou as expectativas paradigmáticas que governam a ciência normal. Segue-se então uma exploração mais ou menos ampla da área onde ocorreu a anomalia. Esse trabalho somente se encerra quando a teoria do paradigma for ajustada, de tal forma que o anômalo se tenha convertido no esperado.'

Por tudo o que foi apresentado até agora, torna-se claro que o paradigma conduz a uma certa "rigidez" na ciência, fazendo com que a própria percepção de uma anomalia seja difícil para a maior parte dos cientistas. Por outro lado, são justamente os mais especializados pesquisadores aqueles capazes de reconhecê-la, pois sabem com precisão o que é esperado:

\footnotetext{
${ }^{4}$ Ibid., p. 39.

${ }^{5}$ Ibid., p. 78.
} 
"A anomalia aparece somente contra o pano de fundo proporcionado pelo paradigma. Quanto maiores forem a precisão e o alcance de um paradigma, tanto mais sensível este será como indicador de fnomalias e, conseqüentemente, de uma ocasião para a mudança de paradigma."

É esse caráter aparentemente paradoxal, presente na articulação de paradigmas, que pode levar a uma "crise" na ciência, e a uma posterior "revolução científica". Nos momentos de crise, o paradigma vigente deixa de oferecer respostas aos quebra-cabeças da ciência normal, gerando uma situação de insegurança profissional. Mesmo assim, de modo algum abandona-se o paradigma. A necessidade de modificá-lo, no entanto, permite, durante um certo período, a flexibilização das regras e a oportunidade de desenvolvimento de novas teorias. Essa "proliferação" é, para Kuhn, um sintoma de crise.

Não há razões objetivas que permitam estabelecer quando ou de que modo uma anomalia irá gerar uma crise. Entretanto, uma vez estabelecida, a crise pode encerrar-se de três maneiras, segundo Kuhn: $1^{\text {a }}$ ) a ciência normal acaba mostrando-se capaz de resolver o problema; $2^{\mathrm{a}}$ ) o problema é abandonado para ser resolvido por gerações futuras que disponham de equipamentos mais sofisticados, ou $3^{\mathrm{a}}$ ) por meio de uma "revolução científica", com a emergência de um novo candidato a paradigma e uma batalha para sua aceitação.

A revolução científica está longe de ser, para o autor, um processo de natureza cumulativa. Trata-se de uma transição entre o velho paradigma (em crise) e um novo. Essa, entretanto, envolve essencialmente uma ruptura, uma transformação radical da visão de mundo dos cientistas, de seus métodos e objetivos.

Durante esse período, desenvolve-se o que Kuhn chama de "pesquisa extraordinária", onde há espaço para criação de teorias especulativas, questionamentos de princípios básicos do campo de estudos em questão, e outras atitudes que se assemelham à imagem corrente do cientista. Como sempre, a história da ciência fornece-nos exemplos desse tipo de pesquisa, como as dificuldades de Kepler com o movimento de Marte ou o desenvolvimento inicial da física de partículas que, inclusive, levou boa parte dos maiores cientistas da época a questionar a própria conservação da energia.

\footnotetext{
${ }^{6}$ Ibid., p. 92.
} 
A pesquisa extraordinária também pode proliferar novas descobertas, em virtude da atenção devotada pelos cientistas em torno da(s) anomalia(s).

A emergência e aceitação de um novo paradigma redefine a prática científica normal em toda sua amplitude: os problemas válidos (o que "é" ou "não é" ciência), os padrões aceitos de solução, a linguagem adequada etc. Segundo Kuhn, o cientista passa a viver em "outro mundo", incomensurável com o anterior:

"A tradição científica normal que emerge de uma revolução científica é não somente incompatível, mas muitas vezes verdadeiramente incomensurável com aquela que a precedeu."

Seria incorreto, portanto, acreditar que a mecânica newtoniana seja um caso particular da teoria da relatividade de Einstein. Ainda que as leis da primeira possam ser "deduzidas", por via matemática, da última, de forma alguma os conceitos einsteinianos de massa, energia, tempo, espaço etc correspondem aos conceitos newtonianos de mesmo nome.

O conceito de incomensurabilidade é fundamental na obra de Kuhn, e terá grande importância para as conclusões a que pretendemos chegar. Ao olhar para um fenômeno, o cientista o faz através de um "óculos" conceitual que pressupõe, essencialmente, um paradigma. Ao analisar a própria percepção visual de figuras, Kuhn afirma suspeitar que algo semelhante a um paradigma seja seu pré-requisito:

"O que um homem vê depende tanto daquilo que ele glha como daquilo que sua experiência visual-conceitual prévia o ensinou a ver.'

Desta forma, um aristotélico não via o mesmo céu que um copernicano, do mesmo modo que um adepto da teoria da relatividade não o vê da mesma maneira que Newton. Essas alterações são tão profundas que não podemos dizer que os fatos permaneceram os mesmos, enquanto mudaram as interpretações. Mais do que isso, o próprio mundo no qual o cientista encontra-se agora é outro:

"Defrontado com a mesma constelação de objetos que antes e tendo consciência disso, ele gs encontra, não obstante, totalmente transformados em muitos de seus detalhes.

\footnotetext{
${ }^{7}$ Ibid., p. 138.

${ }^{8}$ Ibid., p. 148.

${ }^{9}$ Ibid., p. 157.
} 
Seria possível, no entanto, estabelecer critérios neutros capazes de levar um grupo de cientistas a decidir-se por um ou outro paradigma? Como procedem os cientistas diante de teorias rivais? Para Kuhn, a escolha entre paradigmas, nos momentos de crise, coloca questões que não podem ser resolvidas por quaisquer critérios da ciência normal. Os debates entre paradigmas freqüentemente assemelham-se a um "diálogo de surdos", que evidencia a ruptura que está por vir, e justifica o termo "revolução,"10.

"Precisamente por tratar-se de uma transição entre incomensuráveis, a transição entre paradigmas em competição não pode ser feita passo a passo, por imposição da Lógica e de experiências neutras. Tal como a mudança da forma (Gestalt) visual, a transição deve ocorrer subitamente (embora não necessariamente num instante) ou então não ocorre jamais.

E, freqüentemente, ela não ocorre. Há diversos exemplos históricos que corroboram essa visão. Dentre eles, poderíamos citar as dificuldades de aceitação das idéias de Copérnico, Newton, Darwin, Einstein, entre outros.

Segundo Kuhn, a aceitação de um novo paradigma é um processo complexo que, no que se refere aos cientistas individuais, envolve razões aparentemente fora da esfera científica, como crenças e idiossincrasias pessoais. Podem existir também argumentos de natureza estética, como a "beleza" ou "simplicidade" da teoria.

Isso tudo não significa, porém, que não existam "boas razões" para a adesão a um novo paradigma. A resolução de problemas cruciais que levaram o antigo paradigma à crise é uma delas, mas dificilmente ela seria suficiente, uma vez que, "desarticulado", o novo paradigma ainda é uma promessa. A fé nessa promessa pode levar à adesão de um número cada vez maior de cientistas, que aperfeiçoarão o novo paradigma:

"Muitos cientistas serão convertidos e a exploração do novo paradigma prosseguirá. $O$ número de experiências, instrumentos, artigos e livros baseados no paradigma multiplicar-se-á gradualmente. Mais cientistas, convencidos da fecundidade da nova concepção, adotarão a nova maneira de praticar a ciência normal, até que restem apenas alguns poucos opositores mais velhos.'

O novo paradigma, embora incomensurável com o anterior, deve garantir a preservação de boa parte das realizações científicas passadas, estabelecidas por paradigmas anteriores, e ao mesmo tempo permitir a solução de novos problemas.

${ }^{10} \mathrm{O}$ autor procura, no capítulo 8 , traçar também alguns paralelos entre as revoluções políticas e científicas, visando uma mais ampla justificativa do uso dessa expressão.

${ }^{11}$ Ibid., p. 190. 
A "adesão" a um paradigma, assim como a própria prática da ciência normal que dele decorre, embora sejam por um lado processos individuais, por outro são também coletivos, pois ocorrem no seio de uma "comunidade científica". É esse grupo de profissionais que, de modo bastante esotérico, é capaz de abraçar um paradigma em detrimento de outro e resolver os quebra-cabeças da ciência normal. É em seu interior que ocorrem as revoluções:

"Os membros do grupo, enquanto indivíduos e em virtude de seu treino e experiência comuns, devem ser vistos como os únicos conhecedores das regras do jogo ou de algum critério equivalente para julgamentos inequívocos. (...) A comunidade científica é um instrumento extremamente eficaz para maximizar o número e a precisão dos problemas resolvidos por intermédio da mudança de paradigma.'

Esperamos, até aqui, ter conseguido delinear uma visão (ainda que breve e incompleta) da atividade científica e do seu processo de desenvolvimento histórico, a partir do referencial epistemológico de Thomas S. Kuhn.

A essa altura, consideramos haver fornecido uma resposta possível à primeira das duas questões colocadas no início desse capítulo: o caráter conservador da ciência não está em desacordo com as profundas transformações sofridas por ela ao longo da história. Pelo contrário, é justamente através da prática (conservadora) da ciência normal que a novidade, a transformação, enfim, a revolução científica pode ocorrer, trazendo consigo uma nova visão de mundo, uma nova metodologia, novos padrões e valores científicos, novos equipamentos $e$ fenômenos, um novo "olhar" sobre a natureza, um novo paradigma. A mola propulsora do devir científico seria então o binômio rupturacontinuidade.

Entretanto, a segunda questão, referente ao possível estabelecimento de uma visão de progresso da ciência a partir desse binômio, parece-nos um pouco mais delicada. Veremos a seguir qual visão de progresso subjaz à epistemologia kuhniana, e tentaremos, inicialmente, complementá-la com algumas idéias a esse respeito desenvolvidas por Gaston Bachelard para, em seguida, confrontá-la com a proposta epistemológica de Paul Feyerabend.

\footnotetext{
${ }^{12}$ Ibid., p. 199-200.

${ }^{13}$ Ibid., p. 211.
} 
Esse caminho levar-nos-á a adotar a epistemologia kuhniana de uma forma não dogmática, incorporando elementos importantes de outras epistemologias.

\section{I.2. O PROGRESSO EM CIÊNCIA}

A verdade é filha do tempo, e não da autoridade.

Galileu Galilei

Kuhn defende, em seu trabalho, uma visão de progresso científico que poderíamos, quem sabe, chamar de "evolucionária", dadas as analogias que traça entre o desenvolvimento das idéias científicas e o das espécies. Entretanto, alerta-nos o autor quanto ao seu receio de que essa analogia possa ser levada longe demais. Aliás, esse é justamente o principal risco do pensamento por analogias.

Inicialmente, Kuhn assevera que durante a fase pré-paradigmática (ou nas revoluções) as várias escolas competidoras podem, internamente, progredir. Mas isso não representa o "progresso" desse particular campo de estudos. Somente quando predomina a prática científica normal é que esse progresso parece assegurado aos membros da comunidade. Isso justificaria o freqüente debate, em áreas do conhecimento nas quais não há um paradigma dominante, acerca da "cientificidade" ou não do próprio trabalho desenvolvido:

"O progresso científico não difere daquele obtido em outras áreas, mas a ausência, na maior parte dos casos, de escolas competidoras que questionem mutuamente seus objetivos e critérios, torna bem mais fácil perceber o progresso de uma comunidade científica normal.'

Mas que espécie de "progresso" é esse? Kuhn nega a possibilidade de que a ciência esteja cada vez mais aproximando-se da "verdade", o que não implica que não possa haver um desenvolvimento e aprimoramento da compreensão humana:

"O processo de desenvolvimento descrito neste ensaio é um processo de evolução a partir de um início primitivo - processo cujos estágios sucessivos caracterizamse por uma compreensão sempre mais refinada e detalhada da natureza. Mas

\footnotetext{
${ }^{14}$ Essa frase, atribuída a Galileu, parece remontar à Grécia antiga, e ter sido muito usada no século XVI. Ver WHITROW, G. J. - O Tempo na História: concepções do tempo da pré-história aos nossos dias, 1993, p. 154.

${ }^{15}$ KUHN, T. S. - Op. cit., p. 205.
} 
nada do que foi ou será dito transforma-o num processo de evolução em direção a algo.'

De modo análogo, a teoria da evolução de Charles Darwin, proposta em 1859, além de contestar o "criacionismo" dominante, estabeleceu uma visão de progresso semelhante, onde os organismos evoluem a partir de outros, mas não em direção à perfeição.

Nesse ponto seria interessante sermos um pouco cautelosos: o termo "evolução", no interior da biologia (e de acordo com as idéias de Darwin), não denota progresso no sentido de que uma determinada espécie seja "melhor" do que outra que possa ser considerada sua ancestral. O "melhor" aqui deve ser compreendido como "melhor adaptado àquele particular ambiente", contextualizado espacial e historicamente. Apenas para exemplificar, poderíamos citar a bem conhecida hipótese de uma guerra nuclear total que viesse a dizimar a espécie humana. Nesse caso, imagina-se que algumas espécies (as baratas, por exemplo) sobreviveriam, o que não significa, no âmbito da Biologia, dizer que essas espécies sejam melhores ou piores do que a nossa. Estariam, simplesmente, mais adaptadas ao novo ambiente.

O problema a ser contornado é que tanto a palavra evolução como a palavra progresso veiculam comumente uma idéia de melhoria, avanço, alteração num sentido "favorável", e talvez esses não sejam os melhores termos para associarmos às idéias evolucionistas. 1 A questão pode ser bastante delicada, se pensarmos que os próprios significados comuns dessas palavras podem estar relacionados a inadequadas interpretações da própria teoria de Darwin, bem como a tentativas históricas de aplicá-la a outros setores (darwinismo social), o que torna essa analogia epistemológica ainda mais perigosa. Além disso, despreza-se freqüentemente que o pretenso "avanço" em uma certa área do conhecimento pode acarretar uma série de novos e graves problemas. Um exemplo: fala-se em "progresso" da física nuclear, muitas vezes, associando-o a um "avanço"; mas esquece-se que esse processo trouxe em seu bojo mais uma possibilidade de destruição da espécie humana.

Feitas essas ressalvas quanto a uma possível conceituação positivista de progresso, parece-nos justificado afirmar que o progresso biológico representa, antes de tudo,

\footnotetext{
${ }^{16}$ Ibid., p. 213.

${ }^{17}$ Uma rápida inspeção no dicionário confirma o que estamos afirmando, uma vez que o termo "evolução" encontra-se associado a "progresso" (e vice-versa), havendo uma acepção desse último que indica avanço, melhoria etc. FERREIRA, A. B. H. - Novo Dicionário da Língua Portuguesa, $2^{a}$ edição, 1986.
} 
modificação, transformação. Mas algo permanece na mudança (não é essa justamente a idéia de trans-formar?): é a continuidade na ruptura (o nosso binômio!).

Voltando agora a Kuhn, ele procura, de modo semelhante, estabelecer a noção de progresso científico como um processo unidirecional e irreversível, onde há rupturas e continuidades que vêm, ao longo dos séculos, transformando nossa visão e compreensão da natureza. Esse progresso caracteriza-se por forjar instrumentos (paradigmas) cada vez mais adequados para descobrir e resolver quebra-cabeças, mas $\underline{\text { não }}$ por aproximar-nos do "real", no sentido ontológico:

"Não tenho dúvidas, por exemplo, de que a Mecânica de Newton aperfeiçoou a de Aristóteles e de que a Mecânica de Einstein aperfeiçoou a de Newton enquanto instrumento para a resolução de quebra-cabeças. Mas não percebo, nessa sucessão, uma direção coerente de desenvolvimento ontológico. Ao contrário: em alguns aspectos importantes, embora de maneira alguma em todos, a Teoria Geral da Relatividade de Einstein está mais préxima da teoria de Aristóteles do que qualquer uma das duas está da de Newton."

Gostaríamos agora de, a partir dessa última citação de Kuhn, tentar levar um pouco mais adiante a analogia. Trata-se de um progresso entre incomensuráveis, um progresso que é (frisemos isso) transformação. Ora, sendo "incomensurável", como falar em progresso?

Parte da resposta já foi dada, uma vez que o processo de ruptura-continuidade representado pelas revoluções científicas e pela prática da ciência normal preserva, em grande parte, as realizações científicas passadas. Ainda que esse processo não seja de modo algum cumulativo, pois a mudança de paradigma representa uma transformação radical no mundo do cientista, o "novo" conhecimento resgata parte do anterior, sob nova ótica.

A evolução das espécies também assemelha-se a um "progresso entre incomensuráveis", ainda mais se pensarmos que o "mundo" (ambiente) de milhares de anos atrás é realmente outro mundo. Forçando a comparação, diríamos que esse mundo transformado (incomensurável com o nosso) era propício para certas espécies que compartilhassem de um determinado "paradigma biológico". As mudanças concomitantes de ambiente e das espécies representam um processo do tipo rupturacontinuidade, no qual boa parte do "conhecimento biológico" é resgatado por gerações subseqüentes (material genético etc), havendo possibilidades de radicais transformações. 
O nosso objetivo aqui não é o de levar essa analogia às últimas consequiências, mas apontar a possível riqueza que podemos dela extrair e, com isso, fortalecer e clarear conceitualmente a noção de progresso esboçada nessas linhas.

Para compreendermos melhor de que modo a "Mecânica de Einstein aperfeiçoou a de Newton", como aponta Kuhn, apresentaremos a seguir alguns aspectos da epistemologia de Gaston Bachelard que nos sugerem uma espécie de complementação das idéias kuhnianas expostas acima, embora as reflexões de Bachelard tenham sido desenvolvidas entre trinta e quarenta anos antes das de Kuhn.

Bachelard segue, no entanto, outro caminho. Analisa não apenas, mas principalmente, as grandes transformações ocorridas na física no início desse século com a teoria da relatividade e com a mecânica quântica. Nelas busca subsídios que evidenciem a emergência de um "novo espírito científico", estritamente relacionado a uma "filosofia do não".

Em sua obra intitulada O Novo Espírito Científico, escrita em 1934, o autor defende a tese de que não há, para a filosofia científica, realismo ou racionalismo absolutos. O realismo não pode mais ser um realismo imediato, e o racionalismo não pode mais ser um racionalismo fechado. A prova científica afirma-se na experiência e no raciocínio, no contato com a realidade e numa referência à razão. No entanto, o vetor epistemológico vai do racional para o real: é o que Bachelard chama de realização do racional ou realização do matemático. Nesse contexto, a experiência tem um forte vínculo com a teoria, não é mera observação:

"O tempo das hipóteses desconexas e móveis passou, como passou o tempo das experiências isoladas e curiosas. Daqui em diante, a hipótese é síntese. (...) Toda verdade nova nasce apesar da evidência, toda experiência nova nasce apesar da experiência imediata."

O "real científico" coloca-se então em relação dialética com a "razão científica". Escrita seis anos mais tarde, A Filosofia do Não procura estabelecer as bases filosóficas do novo espírito científico. Ao fazê-lo, Bachelard esclarece-nos ainda mais sobre a forte relação que se estabelece entre o realismo e o racionalismo, que se complementam numa filosofia científica com dois pólos:

\footnotetext{
${ }^{18}$ KUHN, T. S. - Op. cit., p. 253.

${ }^{19}$ BACHELARD, G. - O Novo Espírito Científico, 2a edição, 1985, p. 14-15.
} 
"O valor de uma lei empírica prova-se fazendo dela a base de um raciocínio. Legitima-se um raciocínio fazendo dele a base de uma experiência. (...) Pensar cientificamente é colocar-se no campo epistemológico intermediário entre teoria e prática, entre matemática e experiência. Conhecer cientificamente uma lei natural, é conhecê-la simultaneamente como fenômeno e como número.

Bachelard reafirma a sua caracterização da filosofia da ciência física moderna como sendo um movimento epistemológico que vai do racionalismo à experiência (vetor epistemológico). Esse novo racionalismo é um racionalismo "prospector", "realizante", que se aplica e modifica-se, dialetizando seus próprios princípios. Esses seriam alguns aspectos representativos de uma filosofia aberta e dispersa, necessária à compreensão da complexidade do pensamento científico das primeiras décadas desse século.

Voltemos, por um instante, a O Novo Espírito Científico.

Com vistas à exemplificação das características do novo pensar e fazer científicos, Bachelard analisa a "transição" da geometria euclidiana para as geometrias nãoeuclidianas, do sistema de Newton para a mecânica não-newtoniana, do determinismo clássico ao indeterminismo quântico, assim como alguns aspectos ontológicos e epistemológicos que surgem com a Mecânica Quântica. Para aquilo que nos detém a atenção nesse momento, será suficiente apresentar a visão bachelardiana da passagem da mecânica newtoniana ao sistema de Einstein.

Bachelard defende que não há uma transição entre o sistema newtoniano e o de Einstein, no sentido de que não se pode passar do primeiro ao segundo por meio do acúmulo de conhecimentos, melhor acuidade das medidas e retificação ligeira de princípios. Deve haver uma ruptura:

"O pensamento newtoniano era de saída um tipo maravilhosamente transparente de pensamento fechado; dele não se podia sair a não ser por arrombamento.'

Trata-se, pois, de uma "indução transcendente", e não de uma "indução amplificante", o caminhar que nos leva de um pensamento a outro. A "generalização" ocorre a posteriori, uma vez que é possível obter a mecânica de Newton como caso particular da mecânica einsteiniana.

\footnotetext{
${ }^{20}$ BACHELARD, G. - A Filosofia do Não, $5^{\text {a }}$ edição, 1991, p. 10.

${ }^{21}$ BACHELARD, G. - O Novo Espírito Científico, $2^{\mathrm{a}}$ edição, 1985, p. 43.
} 
Deve-se a "transcendência" ao fato de que, nessa passagem (que é ruptura), os conceitos clássicos adquirem um novo sentido, cuja clareza teórica dá-se em função dessa própria mudança. Assim aconteceu com várias noções, como posição, espaço, tempo, velocidade, simultaneidade, massa, energia etc:

“As coisas caminham juntas, os conceitos e a conceptualização; não se trata de palavras que mudam de sentido enquanto que a sintaxe seria invariável, menos ainda de uma sintaxe, móvel e livre, que voltaria sempre a encontrar as mesmas idéias a organizar. As relações teóricas entre as noções modificam as definições das noções tanto Æuanto uma modificação na definição das noções modifica suas relações mútuas."

Por fim, Bachelard ressalta o papel da matemática (particularmente o cálculo tensorial) no desenvolvimento dessa nova física. Para ele, a matemática inaugura e expressa novas possibilidades experimentais. $\mathrm{O}$ pensamento matemático é capaz de criar a física, dando um novo caráter à experiência e à própria realidade:

"Desta organização matemática das possibilidades experimentais, volta-se então à experiência por vias mais diretas. Encontra-se o real como um caso particular do possível. Esta perspectiva é sem dúvida própria para marcar o alargamento do pensamento científico."23

É justamente vinculada a essa idéia de "alargamento", de uma mecânica nãonewtoniana que é (resguardada a transcendência) na verdade pan-newtoniana, que podemos começar a vislumbrar o conceito de progresso em Bachelard. Mas isso ainda não é tudo.

Bachelard vai mais além, apontando o caráter mutável da metodologia científica, bem como a inversão epistemológica necessária para fundar-se uma epistemologia nãocartesiana. Para Descartes (como assinala Louis de Broglie 24, deveríamos nos esforçar para descrever os fenômenos naturais em termos de figuras e movimentos. A física moderna, que aspira à síntese entre matéria e irradiação, opõe-se radicalmente a isso. A epistemologia não-cartesiana seria então uma "condenação da doutrina das naturezas simples e absolutas", que contrapõe-se ao "ideal de complexidade da ciência contemporânea". ".5 Uma vez que propriedades decorrem de relações, não há mais sentido o estudo do fenômeno simples, porque ele não existe. Além disso, a

\footnotetext{
${ }^{22}$ Ibid., p. 50-51.

${ }^{23}$ Ibid., p. 55.

${ }^{24}$ Apud BACHELARD, G. - Op. cit., p. 123.
} 
possibilidade de que um novo postulado venha acrescentar-se ao conhecimento estabelecido, desdobrando-o, representa:

“(...) ainda uma atitude que ultrapassa, prolonga, amplifica a prudência cartesiana e que merece ser chamada não-cartesiana, sempre no mesmo sentido em que o não-cartesianismo é cartesianismo completado.'

Surge então a "filosofia do não" como uma atitude construtiva e de conciliação, e não de negativismo ou recusa. Para Bachelard a ciência e o espírito são fatores de evolução. Mas em que bases filosóficas podemos estabelecer essa evolução?

Em A Filosofia do Não Bachelard considera o conhecimento como uma evolução do espírito, e defende que existam certas "fases" atravessadas durante a evolução filosófica de um conhecimento científico particular. Essas fases iriam do animismo (ou realismo ingênuo) ao ultra-racionalismo, passando pelo realismo (ou empirismo claro e positivista), e pelo racionalismo tradicional. $\mathrm{O}$ ultra-racionalismo engloba o que o autor chama de racionalismo complexo e o racionalismo dialético.

Bachelard defende que tanto o conhecimento de um certo conceito científico, em sua história, como o conhecimento desse mesmo particular conceito por um indivíduo, são movimentos que atravessam essas fases. No entanto, alerta-nos que, assim como nem todos os conceitos científicos encontram-se no mesmo estágio de desenvolvimento, o pensamento do cientista também não é homogêneo. Encontramos, em ambos os casos, os diferentes conceitos em estágios diferentes. Isso concretiza-se na proposta bachelardiana de perfil epistemológico, que discutiremos mais adiante.

A evolução epistemológica de um conhecimento particular caminha, para o autor, no sentido de uma coerência racional. Permitir-nos-emos citar um trecho mais longo, no qual Bachelard defende o progresso filosófico dos conceitos científicos:

"Pode-se discutir muito acerca de progresso moral, do progresso social, do progresso poético, do progresso da felicidade; existe no entanto um progresso que é indiscutível: o progresso científico, considerado como hierarquia de conhecimentos, no seu aspecto especificamente intelectual. Vamos pois tomar para eixo do nosso estudo filosófico o sentido desse progresso, e se, sobre a abcissa da sua evolução, colocarmos regularmente os sistemas filosóficos numa ordem idêntica para todos os conceitos, ordem essa que vai do animismo ao ultra-racionalismo passando pelo realismo, pelo positivismo e pelo racionalismo

\footnotetext{
${ }^{25}$ BACHELARD, G. - Op. cit., p. 125-127.

${ }^{26}$ Ibid., p. 141.
} 
simples, teremos o direito de falar de um progresso filosófico dos conceitos científicos.

Para ilustrar tal concepção, Bachelard trabalha inicialmente com o conceito de massa. Em sua forma animista, a massa aparece como "uma apreciação quantitativa grosseira" da realidade, relacionada essencialmente às "coisas grandes". Encaixam-se aqui visões de senso comum que atribuem uma maior massa a um objeto maior, ou que somente a consideram como uma quantidade quando suficientemente grande.

Um segundo nível corresponderia a uma noção empirista de massa, vinculada a uma pretensa determinação objetiva e precisa. Bachelard refere-se a uma "conduta da balança", que escamoteia uma complicação teórica por trás de um instrumento aparentemente simples, criando um pragmatismo seguro. Denomina de realista o tipo de pensamento associado a essa noção, caracterizando-o:

"A um tal conceito simples e positivo, a uma tal utilização simples e positiva de um instrumento (mesmo que seja teoricamente complicado) corresponde um pensamento empírico, sólido, claro, positivo, imóvel. (...) Pesar é pensar. Pensar é pesar. ${ }^{28}$

As "condutas realistas" persistem mesmo numa ciência que já se encontre em outros estágios. O conceito racionalista de massa nasce, para Bachelard, com a mecânica newtoniana, que o insere num "corpo de noções". Já não representa uma experiência imediata e direta, mas define-se com referência a outras noções (força e aceleração), sendo uma espécie de "coeficiente de devir". É enquanto relação.

A articulação matemática da mecânica newtoniana leva à mecânica racional, que intensifica o caráter simbólico da noção de massa, que passa a ser um "instante da construção racional"'.

Com a teoria da relatividade vemos a noção absoluta de massa sofrer uma abertura. Deixa de ser um conceito relacionado a outros para tornar-se um conceito complexo em si, múltiplo. A massa agora é função da velocidade, e não é mais heterogênea à energia. $\mathrm{O}$ racionalismo complexo surge da multiplicação, segmentação e pluralização do racionalismo tradicional. A abertura dá-se no "interior da noção".

Por último, Bachelard apresenta o conceito de massa presente na mecânica de Dirac como um exemplo do ultra-racionalismo dialético. A idéia de "massa negativa"

\footnotetext{
${ }^{27}$ BACHELARD, G. - A Filosofia do Não, $5^{\text {a }}$ edição, 1991, p. 21.

${ }^{28}$ Ibid., p. 26.
} 
sugere uma ruptura com o pensamento racionalista anterior, e suscita uma "dialética externa", que não poderia ser encontrada refletindo-se sobre as noções anteriores de massa. Temos agora um conceito novo, que surge desvinculado da realidade comum, mas que a matemática procurará "realizar":

"Deste modo a realização leva a melhor sobre a realidade. (...) Um físico só conhece verdadeiramente uma realidade quando a realizou, quando deste modo é senhor do eterno recomeço das coisas e quando constitui nele um retorno eterno

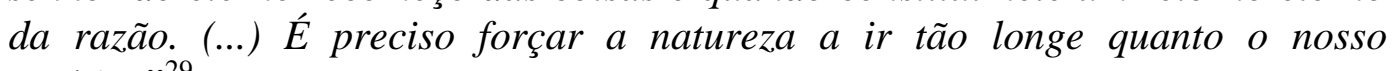
espirito."

O importante nesse momento para nós não seria, sem dúvida, aprofundar essa discussão sobre o conceito de massa. Isso nos serviu como ilustração de como as diversas doutrinas filosóficas propostas por Bachelard podem encontrar-se presentes no desenvolvimento filosófico de um determinado conceito científico, e de como decorre daí uma certa visão de progresso. Mas faz questão de lembrar-nos o autor que as diversas filosofias parciais esclarecem, cada uma, apenas uma face do conceito.

Como foi dito anteriormente, nem todo conceito particular, nem toda área do conhecimento, encontram-se no mesmo estágio com relação à hierarquia de doutrinas filosóficas. Mais do que isso, os próprios pensamentos dos cientistas teriam coeficientes de realismo ou de racionalismo diversos, não havendo sentido em os classificarmos simplesmente sob os rótulos de "realistas" ou "racionalistas". Bachelard se pergunta, por exemplo:

"Os coeficientes de realidade não diferirão consoante as noções, de acordecom a evolução dos conceitos, de acordo com as concepções teóricas da época?" "30]

É dentro dessa "filosofia dispersa" que surge o conceito de perfil epistemológico, segundo o qual as diferentes doutrinas filosóficas encontram, no indivíduo, um certo "peso relativo", uma certa "intensidade de presença":

"Insistimos no fato de um perfil epistemológico dever sempre referir-se a um conceito designado, de ele apenas ser válido para um espírito particular que se examina num estádio particular da sua cultura.'

Desse modo, o perfil epistemológico de um indivíduo, referente ao conceito de massa, pode ser bastante diferente daquele referente à energia. Além disso, há uma

\footnotetext{
${ }^{29}$ Ibid., p. 34-35.

${ }^{30}$ Ibid., p. 39.

${ }^{31}$ Ibid., p. 41.
} 
permanência das idéias filosóficas no desenvolvimento intelectual de cada indivíduo. Bachelard traça os seus próprios perfis referentes a esses dois conceitos 2 .

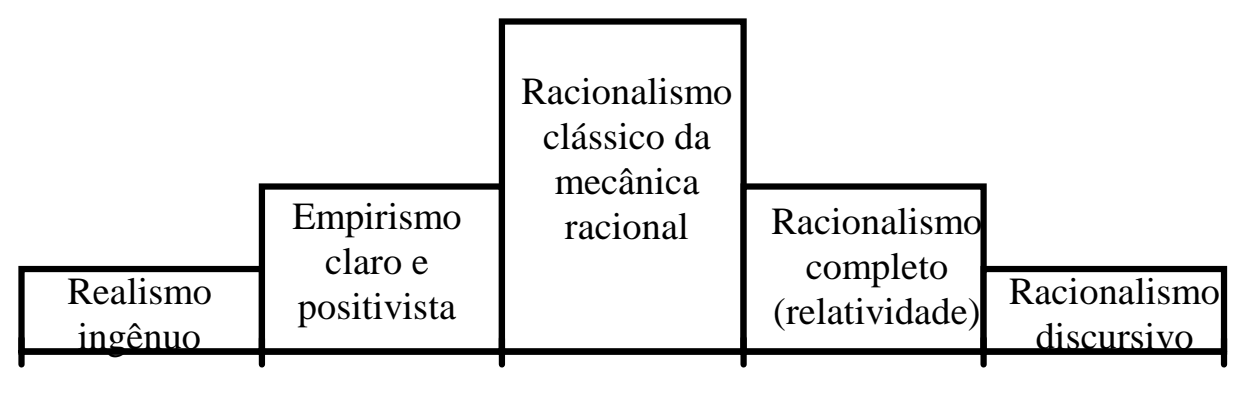
1 2 3 4 5

Perfil epistemológico referente ao conceito de massa de Bachelard.

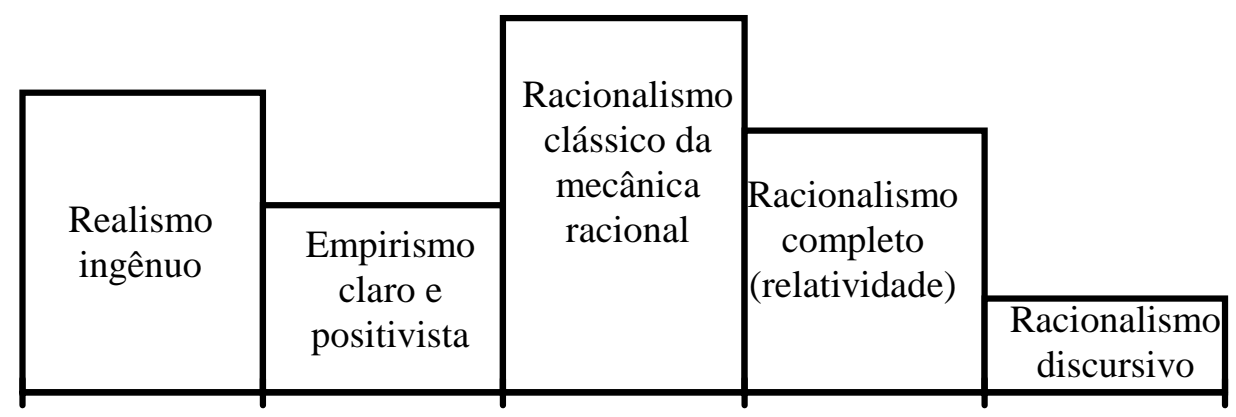

Perfil epistemológico referente ao conceito de energia de Bachelard.

Há a necessidade então de um pluralismo filosófico se quisermos compreender a complexidade do novo espírito científico. Esse caráter disperso encontra uma coesão na própria idéia de progresso filosófico:

"A nossa conclusão é pois clara: uma filosofia das ciências, mesmo se se limita ao exame de uma ciência particular, é necessariamente uma ciência dispersa. Tem no entanto uma coesão, a da sua dialética, a do seu progresso. Todo o

\footnotetext{
${ }^{32}$ Ibid., p. 41 e 43.
} 
progresso de uma filosofia das ciências se faz no sentido de um racionalismo crescente, eliminando, a propósito de todas as noções, o realismo inicial., 33

Em capítulos subseqüentes, Bachelard segue outros caminhos em sua defesa da filosofia do não, discutindo por exemplo uma química não-lavoisiana e uma lógica nãoaristotélica. Reitera que essa filosofia propõe a "reorganização do saber numa base alargada", não representando uma negação. Nesse sentido, a dialética associada ao ultraracionalismo opera considerando visões opostas como complementares (e não contraditórias) para uma síntese:

"A generalização pelo não deve incluir aquilo que nega. De fato, todo o desenvolvimento do pensamento científico de há um século para cá provém de tais generalizações dialéticas com envolvimento daquilo que se nega. Assim a geometria não-euclidiana envolve a geometria euclidiana; a mecânica nãonewtoniana envolve q-necânica newtoniana; a mecânica ondulatória envolve a mecânica relativista.",

O novo pensar científico ordena a própria filosofia, reorientando a própria racionalidade:

"Em suma, a ciência instrui a razão. A razão deve obedecer à ciência mais evoluída, à ciência em evolução."

\section{I.3. ALGUMAS RELAÇÕES POSSÍVEIS ENTRE EPISTEMOLOGIAS DE KUHN E BACHELARD}

Esperamos, através do exposto anteriormente, ter conseguido evidenciar em que medida a visão de progresso científico desenvolvida por Gaston Bachelard pode ser considerada complementar àquela presente na epistemologia de Thomas Kuhn. Ainda que as obras analisadas estejam separadas por cerca de três décadas, e que os dois autores sigam trilhas bastante diversas, manifestando preocupações um pouco diferentes no que concerne à natureza do empreendimento científico, pensamos haver encontrado profundas relações entre os pensamentos de ambos. Antes de seguirmos adiante, seria interessante resgatarmos algumas delas, destacando desde já que ambos têm na história

\footnotetext{
${ }^{33}$ Ibid., p. 47-48.

${ }^{34}$ Ibid., p. 129.

${ }^{35}$ Ibid., p. 135.
} 
da ciência um referencial privilegiado, o que permite situar suas contribuições na classificação de "epistemologias históricas da ciência".

Em primeiro lugar, ambos trabalham com o binômio ruptura-continuidade quando refletem sobre o desenvolvimento da ciência $e$ do indivíduo. Já explicitamos de que modo isso aparece na epistemologia kuhniana, na qual a mudança entre paradigmas requer uma ruptura. Embora Kuhn enfatize a idéia de "comunidade científica", deixa claro que o indivíduo particular deve ser convertido ao novo paradigma, e discute, como vimos, "boas razões" para essa adesão. Isso significa que a ruptura dá-se na ciência como um todo $\underline{e}$ no indivíduo, em particular. Bachelard, embora não se utilize da noção de paradigma, defende também a idéia de ruptura, que para ele significa um rompimento com os obstáculos epistemológicos que se colocam para o indivíduo. ${ }^{66}$ Sua ênfase encontra-se no indivíduo, no espírito científico que evolui superando obstáculos. E nos fala também ele de uma "conversão":

“Todo o progresso real no pensamento científico necessita de uma conversão. Os progressos do pensamento científico contemporâneo determinam transformações nos próprios princípios do conhecimento.'

A idéia de continuidade parece-nos ainda mais clara em Bachelard, uma vez que no conceito de perfil epistemológico está garantida a permanência das diversas doutrinas filosóficas. Isso representaria um tipo de continuidade conceitual no indivíduo, uma vez que os conceitos "ultrapassados" continuam fazendo parte de sua estrutura cognitiva, podendo ser usados tanto em sua linguagem cotidiana como na resolução de problemas científicos. O "alargamento" filosófico proposto por Bachelard por meio de sua filosofia do não esclarece-nos acerca da natureza da continuidade existente, por exemplo, entre a mecânica newtoniana e a relatividade, que representa um tipo de continuidade conceitual na ciência, não deixando, ao mesmo tempo, de destacar a ruptura existente entre uma e outra.

Esse segundo tipo de continuidade é apontado por Kuhn quando afirma que um paradigma conserva boa parte das realizações científicas passadas, e que o "novo" conhecimento sempre resgata parte do anterior, sob nova ótica. No entanto, o autor não aprofunda muito a natureza desse "resgate", e foi justamente nesse ponto que

\footnotetext{
${ }^{36}$ Bachelard enumera e analisa uma série de tipos de obstáculos na obra A Formação do Espírito Científico (1938), publicada entre O Novo Espírito Científico (1934) e A Filosofia do Não (1940).

${ }^{37}$ BACHELARD, G. - A Filosofia do Não, $5^{\mathrm{a}}$ edição, 1991, p. 12.
} 
consideramos oportuna a introdução de algumas idéias de Bachelard. Quanto ao primeiro tipo de continuidade, ou seja, a continuidade conceitual no indivíduo, Kuhn parece contradizer as teses de Bachelard ao defender que o cientista normal é um devoto exclusivo de um paradigma. A questão é complexa, pois não há correspondência direta entre o "paradigma" kuhniano e a "doutrina filosófica" bachelardiana.

A contradição tende a desaparecer se assumirmos um ponto de vista "bachelardiano", numa tentativa de "alargar" a posição de Kuhn. Afirmaríamos então que o cientista normal pode, por vezes, utilizar-se de paradigmas "ultrapassados", do mesmo modo que se utiliza de noções filosóficas "ultrapassadas". No lançamento de um satélite, por exemplo, pode não ser necessário fazer uso de correções relativísticas, o que garante a aplicação do paradigma newtoniano. Os cientistas envolvidos podem, certamente, pensar, agir e comunicar-se de forma newtoniana ao levar a cabo tal atividade. Isso não significa que não haja um paradigma dominante, pois o cientista sabe que está aplicando parte de um paradigma "ultrapassado". Ainda que não tenha essa clareza durante todo o tempo, tomará o devido cuidado ao escrever um trabalho científico a respeito. Pode-se estabelecer aqui, inclusive, um paralelo com um estudante principiante de física que, em situações de sala de aula, utiliza corretamente a física newtoniana na solução de exercícios típicos, e deixa transparecer a física aristotélica em situações não convencionais.

São os protagonistas de revoluções, entretanto, que nos evidenciam de forma mais contundente como noções filosóficas $\underline{e}$ paradigmas diferentes podem conviver em um mesmo indivíduo. Kuhn salienta a existência de "debates filosóficos" nos momentos de transição. A “ciência extraordinária” é um momento propício para aflorar esse tipo de discussão. Encontramos em Galileu, Planck e Bohr, entre outros, fortes evidências em favor dessa análise, que seria uma interpretação bachelardiana tanto do espírito que articula a ciência normal quanto daquele associado às revoluções científicas.

Chamamos a atenção, nos parágrafos anteriores, para a continuidade existente apesar das rupturas, para a sutil continuidade entre paradigmas incomensuráveis, que pode variar de intensidade e natureza (conceitual, ontológica, formal-matemática etc). Haveria ainda espaço para falarmos em outro tipo de continuidade, presente nos períodos de "calmaria" representados pela prática da ciência normal. Essa seria um tipo explícito de continuidade, é a própria articulação do paradigma. É, mais 
apropriadamente, um continuísmo. É essa continuidade que Kuhn caracteriza como um aspecto cumulativo da ciência normal.

A análise precedente parece-nos relacionar, por fim, as visões do processo ruptura-continuidade em Kuhn e Bachelard, complementando-as. Contudo, não se dá essa complementação de modo tácito, restando uma vastidão de problemas filosóficos “abertos". Por exemplo, o das possíveis relações entre a noção de "paradigma" e a idéia de "doutrina filosófica".

O caráter conservador da atividade científica é bastante evidente na visão kuhniana. Já Bachelard não segue esse caminho, mas deixa claro que, se deve haver rupturas, é porque há obstáculos colocados pela própria prática científica. Ao discutir o conceito de "massa negativa" de Dirac, por exemplo, afirma que para o cientista do século XIX esse conceito pareceria "monstruoso", e seria considerado um erro fundamental. Não seria essa uma situação na qual a ciência normal procura afastar uma anomalia, desconsiderando-a, tratando-a como não-científica? As dificuldades de superação de um racionalismo simples em direção ao ultra-racionalismo evidenciam como:

“(...) as filosofias mais sãs como o racionalismo newtoniano e kantiano podem, em determinadas circunstâncias, constituir um obstáculo ao progresso da cultura.,

Vemos também profundas semelhanças entre a noção de incomensurabilidade de Kuhn e a idéia de transcendência presente em Bachelard. Os dois autores certamente concordam no que se refere à existência de mudanças nos significados de conceitos como espaço, tempo, massa, energia etc, quando analisamos comparativamente as mecânicas de Newton e de Einstein. Entretanto, Kuhn fala de uma transformação radical na visão de mundo do cientista, que passa a viver num "mundo diferente" com a mudança de paradigma. Bachelard não parece ir tão longe, preocupado que está em evidenciar o "alargamento" dos conceitos, característico do novo espírito científico. Ambos, no entanto, concordam quanto à existência de mudanças ontológicas.

Outro ponto importante a considerarmos aqui é em que medida a concepção de progresso filosófico em Bachelard aponta um “destino", um fim último. Seria o ultra-

\footnotetext{
${ }^{38}$ Ibid., p. 42.
} 
racionalismo o estágio final da evolução? Essa é uma questão polêmica, pois vimos que a concepção "evolucionária" do progresso científico, presente em Kuhn, refere-se a uma evolução a partir de, e não em direção $a$. No entanto, parece-nos prematuro atribuir essa idéia "finalista" para a hierarquia proposta por Bachelard. Em nenhum momento ele parece conceber o ultra-racionalismo como algum tipo de "limite superior" em termos de doutrinas filosóficas, colocando um fim ao progresso filosófico dos conceitos. Sua preocupação é, antes, de caracterizar um "novo espírito científico" que surge, e de analisar as bases filosóficas que o sustentam, e que refletem o desenvolvimento histórico correspondente.

Bachelard não "dita regras", e a própria natureza de sua filosofia do não nos parece proibir uma interpretação pretensamente mais "fechada" da proposta bachelardiana. Ousaríamos dizer que o progresso para Bachelard é, sim, "em direção a": mas em direção a uma filosofia aberta que reflete uma racionalidade que se complica, desdobra-se e multiplica as próprias direções possíveis para uma compreensão posterior dos conceitos.

Há uma evolução não em direção à verdade, à compreensão absoluta da natureza, mas em direção à multiplicidade de direções, ao não-absoluto, no sentido da complicação e do desdobramento que os conceitos e teorias sofrem ao longo desse processo. O progresso é epistemológico, e não ontológico, o que nos lembra novamente as idéias de Kuhn, quando defende que a sucessão: teoria aristotélica, mecânica de Newton, e relatividade, não representa uma "direção coerente de desenvolvimento ontológico".

Certamente encontraremos, em ambas as epistemologias, uma série de implicações de natureza educacional. Kuhn e Bachelard ainda têm, nesse aspecto, muito a nos dizer. Deixaremos, entretanto, para um capítulo posterior essas considerações. Por ora, gostaríamos de finalizar com uma pergunta: poderia haver melhores maneiras de promover o progresso científico?

No posfácio de A Estrutura das Revoluções Científicas, Kuhn relata algumas críticas recebidas por seu trabalho, acusando-o de estabelecer uma confusão entre o descritivo e o normativo, entre o "é" e o "deve ser". Vejamos então o que ele diz: 
“As páginas precedentes apresentam um ponto de vista ou uma teoria sobre a natureza da ciência e, como outras filosofias da ciência, a teoria tem conseqüências no que toca à maneira pela qual os cientistas devem comportar-se para que seu empreendimento seja bem sucedido. Embora essa teoria não necessite ser mais correta que qualquer outra, ela proporciona uma base legítima para o uso dos "o que poderia ser" (should)e "o que deve ser" (ought).'

$\mathrm{O}$ autor defende sua teoria dizendo que os cientistas comportam-se como ela prescreve. Na realidade, parece realmente possível fazermos leituras da obra de Kuhn bastante diferentes, que vão desde uma crítica contundente à prática científica até uma prescrição do fazer científico, passando por uma simples descrição despretensiosa.

Há, sem dúvida, "boas razões" para aderirmos a esse "paradigma epistemológico". A principal delas é que (e esperamos tê-la justificado suficientemente!) a proposta de Kuhn parece-nos descrever adequadamente o trabalho dos cientistas e permite-nos compreender a evolução histórica da ciência. Embora essa teoria "não necessite ser mais correta que qualquer outra", compartilhamos com ela uma concepção de como é a ciência. Mas a nossa leitura da obra de Kuhn não nos permite encará-la como uma prescrição, tampouco despretensiosa. Pelo contrário, tomaremos muitas de suas falas como críticas severas quando, em seguida, discutirmos uma concepção educacional que se pretenda transformadora. Sua epistemologia é tomada por nós não de uma forma dogmática, fechada. Resguardamo-nos o direito de incorporar a ela elementos importantes de outras epistemologias, de maneira que, parafraseando Bachelard, essa diversidade permita-nos esclarecer as diversas "faces" da ciência.

Desse modo, quanto à questão colocada acima (poderia haver melhores maneiras de promover o progresso científico?), o trabalho de Kuhn não nos permite estabelecer conjecturas, respondendo talvez com um histórico "não". Mas a epistemologia de Bachelard parece em alguns momentos pregar uma atitude mais crítica e transformadora por parte do cientista. No debate entre realismo e racionalismo, com respeito ao conceito de massa, ele deixa escapar que:

"Só existe um meio de fazer avançar a ciência; é o de atacar a ciência já constituída, ou seja, mudar a sua constituição."

\footnotetext{
${ }^{39}$ KUHN, T. S. - Op. cit., p. 254.

${ }^{40}$ BACHELARD, G. - A Filosofia do Não, $5^{\text {a }}$ edição, 1991, p. 31.
} 
Com isso queremos salientar que, embora a idéia de progresso histórico da ciência seja um elo de ligação entre Kuhn e Bachelard, suas diferentes abordagens sugerem respostas contrárias para a questão colocada por nós. A citação acima parece contradizer a prática da "ciência normal". No entanto, Bachelard não aprofunda essa questão, não estabelece "diretrizes" claras para a prática posterior da ciência, ainda que aponte o aprofundar do pensamento racional.

Consideramos, no entanto, suficientemente apresentada, para os nossos propósitos, a nossa concepção de ciência e de seu desenvolvimento. Contudo, face a essa última polêmica, apresentaremos a seguir uma resposta possível, a partir da análise de algumas idéias defendidas por Paul Feyerabend. Isso levar-nos-á a novas conclusões...

\section{I.4. PODERIA HAVER MELHORES MANEIRAS DE PROMOVER O PROGRESSO CIENTÍFICO?}

Se dois homens se querem entender verdadeiramente, têm primeiro que se contradizer. A verdade é filha da discussão e não filha da simpatia.

Gaston Bachelard 41

Apresentaremos a seguir algumas idéias da epistemologia de Paul Feyerabend, que nos proporciona uma possível resposta à questão acima colocada.

Não conseguiremos (e nem pretendemos) dar conta aqui da amplitude e das implicações que as teses defendidas por esse autor apresentam. O nosso objetivo imediato é acrescentar, às concepções epistemológicas de Thomas Kuhn e Gaston Bachelard, uma alternativa epistemológica que ora complementa, ora contradiz idéias desses dois autores. Ao final, apontaremos em que medida essa nova proposta pode ser encarada como uma possibilidade futura para o desenvolvimento científico, e sua importância quanto à adoção de uma postura epistemológica aberta, que considera a contribuição das várias epistemologias possíveis para a análise da ciência e do fazer científico, bem como para a educação científica e geral. 
Seguiremos um caminho semelhante ao adotado para Kuhn e Bachelard, analisando uma importante obra de Paul Feyerabend: Contra o Método.

O autor defende a tese de que o único princípio capaz de não inibir o progresso científico é: tudo vale. Sua proposta é a de um anarquismo epistemológico, baseado na idéia de que não é viável interpretar o desenvolvimento científico à luz de um método fundamentado em princípios firmes e obrigatórios. A pesquisa histórica mostraria que todas as regras metodológicas são violadas em algum momento:

"É claro, portanto, que a idéia de um método estático ou de uma teoria estática de racionalidade funda-se em uma concepção demasiado ingênua do homem e de sua circunstância social. Os que tomam do rico material da história, sem a preocupação de empobrecê-lo para agradar a seus baixos instintos, a seu anseio de segurança intelectual (que se manifesta como desejo de clareza, precisão, 'objetividade', 'verdade'), esses vêem claro que só há um princípio que pode ser defendido em todas as circunstâncias e em todos os estágios do desenvolvimento humano. É o princípio: tudo vale.,

Feyerabend propõe que devemos agir contra-indutivamente, introduzindo concepções novas na prática da ciência, adotando uma "metodologia pluralista", uma vez que todas as metodologias têm limitações. Nesse bojo, define o papel do anarquista:

"Um anarquista é como um agente secreto que participa do jogo da Razão para solapar a autoridade da Razão (Verdade, Honestidade, Justiça e assim por diante).

Ao abandonar determinadas alternativas teóricas em função de uma única teoria, o cientista procede de maneira conservadora, não havendo razão alguma para fazê-lo. Isso leva a uma "dogmatização" da ciência, a uma transformação de uma teoria em ideologia e mito:

"Resumindo: Unanimidade de opinião pode ser adequada para uma igreja, para as vítimas temerosas ou ambiciosas de algum mito (antigo ou moderno) ou para os fracos e conformados seguidores de algum tirano. A variedade de opiniões é necessária para o conhecimento objetivo. E um método que estimule a variedade é o único método compatível com a concepção humanitarista.

\footnotetext{
${ }^{41}$ Ibid., p. 125.

${ }^{42}$ FEYERABEND, P. - Contra o Método, 1977, p. 34.

${ }^{43}$ Ibid., p. 43-44.

${ }^{44}$ Ibid., p. 57.
} 
A história, segundo Feyerabend, mostra como certas idéias consideradas "científicas" deixam de sê-lo, ocorrendo também o contrário. Qualquer idéia seria capaz, em princípio, de aperfeiçoar o nosso conhecimento. Apesar disso, a ciência e o cientista costumam abraçar teorias esquecendo suas dificuldades e insuficiências, elaborando freqüentemente hipóteses ad hoc.

Entretanto, "nenhuma teoria está de acordo com todos os fatos de seu domínio". Com isso, procura o autor rebater qualquer exigência metodológica, como aquela referente ao confronto teoria-experiência (base do empirismo) ou a proposta de falseamento de teorias. Para Feyerabend o confronto com a experiência não significa uma possibilidade de eliminação de teorias, pois a própria evidência pode estar “contaminada", permeada por características histórico-fisiológicas. As dificuldades enfrentadas pela teoria de Copérnico seriam um exemplo disso.

Feyerabend analisa longamente o trabalho de Galileu, procurando mostrar como ele foi levado a introduzir uma nova "interpretação natural" para concretizar sua oposição aos aristotélicos com referência à mobilidade da Terra. O "fenômeno" constitui-se de aparência mais enunciado, havendo uma conexão profunda entre ambos, fruto de um longo aprendizado:

"Os fenômenos são o que os enunciados associados asseveram que eles sejam. A linguagem que 'falam' está, naturalmente, influenciada pelas crenças de gerações anteriores, mantidas há tanto tempo que não mais parecem princípios separados, apresentando-se nos termos do discurso cotidiano fo parecendo, após o treinamento natural exigido, brotar das próprias coisas.'

Essas “interpretações naturais" são necessárias, mas não as devemos tomar nem como pressupostos a priori, por um lado, nem como preconceitos, por outro. Há um forte vínculo entre sensação e linguagem.

Isso estaria na raiz dos problemas enfrentados por Galileu ao combater a idéia aristotélica de imobilidade da Terra. Os "fatos" não estariam inteiramente a favor dos aristotélicos? Mas Galileu introduz uma nova linguagem de observação:

"A interpretação de que se vale Galileu repõe os sentidos na posição de instrumentos de explgração, mas tão-somente com respeito à realidade do movimento relativo.'

\footnotetext{
${ }^{45}$ Ibid., p. 106-107.

${ }^{46}$ Ibid., p. 114.
} 
Galileu recorre a outros artifícios psicológicos, segundo Feyerabend, como a propaganda, em favor de seu modelo. Inaugura "princípios metodológicos novos" e faz uso de uma nova espécie de experiência, de natureza mais "especulativa":

"Paradoxal, mas não incorretamente, caberia dizer que Galileu inventa uma experiência que tem ingredientes metafísicos. Por meio dessa experiência é que se realiza a trgnsição da cosmologia geostática para o ponto de vista de Copérnico e Kepler.'

O "argumento da torre", defendido pelos aristotélicos em prol de sua teoria, precisava ser reinterpretado à luz da nova dinâmica baseada na relatividade dos movimentos. Para fazê-lo, Galileu precisou lançar mão de hipóteses ad hoc relativas ao movimento da Terra, para que houvesse espaço para a articulação das idéias heliocêntricas.

Contrariamente a algumas concepções, Feyerabend defende que o uso do telescópio por parte de Galileu não permitiu a refutação do geocentrismo, uma vez que o êxito do uso desse instrumento na Terra não garantia a sua aplicabilidade nos céus. Era necessário um avanço da óptica e uma nova teoria da visão. Além disso, não havia concordância relativamente às próprias observações telescópicas! Galileu afirmava ver o que outros não viam, e negou-se a enviar o telescópio a Kepler, que o pediu por intermédio de uma carta.

Para Feyerabend, Galileu busca em duas concepções refutadas (a doutrina copernicana e a idéia de que os fenômenos telescópicos retratam fielmente o céu) uma complementação, no sentido de que é através de seu auxílio mútuo que procurará construir a nova mecânica. O uso do telescópio buscou alterar o "núcleo sensorial" da própria experiência cotidiana, enquanto a nova dinâmica (com o princípio da relatividade do movimento) alterava os "componentes conceituais" dessa experiência. Há um certo "movimento de recuo", no sentido de que dados que apoiavam uma antiga concepção são abandonados em favor de uma teoria de menor conteúdo empírico. O trabalho de Galileu torna claro, para Feyerabend, que:

“(...) a adesão às novas idéias terá de ser conseguida por meios outros que não argumentos. Terá de ser conseguida por meios irracionais, como a propaganda, a emoção, as hipóteses ad hoc e os preconceitos de toda espécie. Tornam-se necessários esses 'meios irracionais' para dar apoio àquilo que não passa de fé

${ }^{47}$ Ibid., p. 132-133. 
cega, até que disponhamos das ciências auxiliares, de fatos, de argumentos que transformem a fé em 'conhecimento' bem fundado. (...)

Em outras palavras: a teoria copernicana e outras concepções 'racionais' só existem hoje porque, em seu passado, a razão, em algumas ocasiões, foi posta em segundo plano.

Feyerabend aponta que uma possível distinção entre "contexto da descoberta" e "contexto de justificação" não ajudaria na interpretação de seus resultados. Seria uma simplificação tão grande e falaciosa quanto a distinção "termos observacionais" e "termos teóricos". A experiência encontra-se fortemente vinculada a pressupostos teóricos, e pode-se abandonar tanto teoria quanto observações.

Propõe-nos então o autor uma epistemologia anárquica, em contraposição às "metodologias que se prendem às regras e à ordem". Sua crítica é endereçada principalmente aos princípios do racionalismo crítico (falseamento de teorias, negação das hipóteses ad hoc etc) e do empirismo lógico (ser preciso, apoiar teorias em medições etc), pois ambos são inadequados para explicar o desenvolvimento passado da ciência, e podem prejudicar seu desenvolvimento futuro:

“Sem 'caos', não há conhecimento. Sem freqüente renúncia à razão, não há progresso. Idéias que hoje constituem a base da ciência só existem porque houve coisas como o preconceito, a vaidade, a paixão; porque essas coisas se opõem à razão; e porque foi permitido que tivessem trânsito.(...) Não há uma só regra que seja válida em todas as circunstâncias, nem uma instância a que se possa apelar em todas as situações. (...)

E, assim, o anarquismo não é apenas possível, porém necessário, tanto para o progresso interng da ciência, quanto para o desenvolvimento de nossa cultura como um todo.'

Conseqüentemente, não há uma maneira racional de criticar um cientista que se apega a teorias "velhas". Tampouco podemos descartar, por meio de qualquer padrão, novas teorias que surgem. Somente a proliferação de teorias é benéfica à ciência.

Analisa Feyerabend em seguida o problema da incomensurabilidade. Para ele, ela ocorre já no "domínio da percepção", onde "estímulos apropriados” face a diferentes “sistemas de classificação" podem produzir objetos de difícil comparação:

\footnotetext{
${ }^{48}$ Ibid., p. 238-239.

${ }^{49}$ Ibid., p. 279.
} 


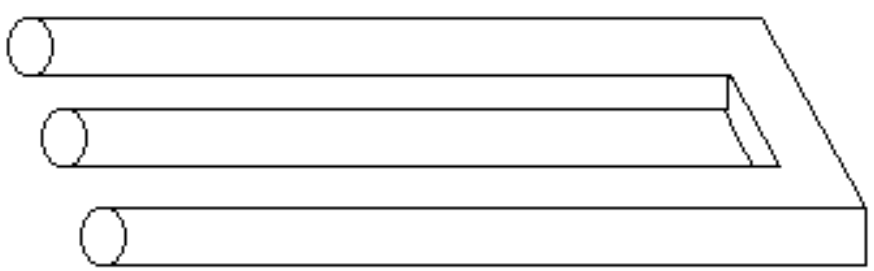

Mas não se limita a esse domínio (embora fundamental) a questão da incomensurabilidade. Analisando exemplos extraídos da história da arte, Feyerabend procura mostrar como os "elementos" de um certo estilo artístico referenciam-se numa certa visão de mundo, numa certa cultura. Sua análise é "antropológica", e é nesses termos que ele pretende que estejam apoiados os seus resultados, que apresenta em forma de teses:

$1^{\text {a }) ~ E x i s t e m ~ " e s q u e m a s ~ d e ~ p e n s a m e n t o ~(a c ̧ a ̃ o, ~ p e r c e p c ̧ a ̃ o) ~ i n c o m e n s u r a ́ v e i s ~ e n t r e ~ s i . " ~}$

$2^{a}$ ) O “desenvolvimento da percepção e do pensamento, no indivíduo, atravessa estágios que são mutuamente incomensuráveis."

$3^{a}$ ) As "concepções dos cientistas e, especialmente, as concepções que têm acerca de questões fundamentais são, freqüentes vezes, tão diferentes entre si quanto as ideologias subjacentes a culturas diversas. Pior ainda: existem teorias científicas mutuamente incomensuráveis, embora aparentemente relativas 'à mesma disciplina'.,

Há alterações conceituais $\underline{e}$ ontológicas no desenvolvimento da ciência, e isso nos evidencia, por exemplo, a incomensurabilidade entre a física clássica e a relatividade. Feyerabend afirma que a relatividade sequer permite que "formulemos enunciados" para expressar o "estado de coisas" do mundo clássico, pois as teorias não compartilham os mesmos "princípios universais". Tampouco podemos associar enunciados clássicos a enunciados relativistas através de uma "hipótese empírica". Contudo, não nega o autor que haja semelhanças entre as teorias. Mas ressalta:

“(...) é certo que esquemas incomensuráveis e conceitos incomensuráveis podem apresentar muitas similaridades estruturais - isso, porém, não afasta o fato de que os princípios universais, próprios de um esquema, são sustados pelo outro. É esse o fato que define a incomgnsurabilidade, a despeito de todas as similaridades que seja possivel descobrir.' 5

\footnotetext{
${ }^{50}$ Ibid., p. 401.

${ }^{51}$ Ibid., p. 404-405.
} 
A continuidade das relações formais entre teorias não implica a continuidade de interpretações.

Por fim, argumenta Feyerabend em favor da separação ciência-Estado, dado o caráter "dogmático" assumido pela primeira, e em função de haver-nos explicitado a estreita relação da prática dessa atividade com a prática da religião, do misticismo etc. Além disso, a ciência seria apenas uma forma de conhecimento válido, mas não necessariamente "a melhor":

"Não há temer que tal separação leve a um colapso da tecnologia. Sempre haverá pessoas que preferirão ser cientistas a ser donos de seus destinos e que se submeterão alegremente à mais desprezível forma de escravidão (intelectual e institucional), contanto que se vejam bem pagas eque tenham em torno de si quem lhes examine o trabalho e lhes cante louvores."

O tratamento diferenciado recebido pela ciência deve-se ao fato, segundo Feyerabend, da ciência posicionar-se como "medida objetiva de todas as ideologias", e não como mera ideologia. Os cientistas clamam para si uma "aura de excelência", mas deveriam assumir "mais modesta posição na sociedade".

Dentro dessa concepção, a separação ciência e não-ciência representa um obstáculo ao progresso do conhecimento:

"Se desejamos compreender a natureza, se desejamos dominar a circunstância física, devemos recorrer a todas as idéias, todos os métodos e não apenas a reduzido número deles.'

\section{I.5. ALGUMAS RELAÇÕES POSSÍVEIS ENTRE AS EPISTEMOLOGIAS DE KUHN, BACHELARD E FEYERABEND}

O "anarquismo epistemológico" de Paul Feyerabend representa uma abordagem tão diferenciada do desenvolvimento científico, e ao mesmo tempo tão marcante, que qualquer tentativa de estabelecermos relações entre essa epistemologia e as concepções de Thomas Kuhn ou Gaston Bachelard atemoriza-nos. No entanto, para os modestos

\footnotetext{
${ }^{52}$ Ibid., p. 454.

${ }^{53}$ Ibid., p. 462.
} 
propósitos do presente trabalho, a permanência por algum tempo na "arena" parece-nos necessária a essa altura, e (por que não dizer?) "estimulante".

Havíamos apontado anteriormente relações possíveis entre Kuhn e Bachelard no que se refere aos seguintes pontos:

- caráter conservador da atividade científica;

- concepção de progresso científico;

- noção de incomensurabilidade;

- idéia de ruptura-continuidade.

Vimos que, embora assumindo abordagens bastante diferentes, esses dois autores concordariam em muitos aspectos, e suas visões apresentam-se-nos complementares em alguns deles.

Os pontos levantados acima também são objetos da análise de Feyerabend (o que por si só já determina a natureza das semelhanças existentes entre os três autores ${ }^{54}$,, cuja proposta fortalece-se em função de sua retórica aguçada e mordaz, e de sua propaganda franca e direta. Aproxima-se das visões de Kuhn em alguns aspectos, afastando-se em outros. O mesmo podemos dizer de Feyerabend em relação a Bachelard.

Quanto ao primeiro ponto, podemos dizer que Feyerabend certamente critica o conservadorismo da ciência, caracterizando-o inclusive como pernicioso. Entretanto, não nega que a prática cotidiana da ciência tenha esse caráter (o que está presente também em Bachelard, como vimos). Pelo contrário, aponta em diversos momentos como o cientista busca justificar o seu apego a uma única teoria ou "programa de pesquisa", bem como a atitude das instituições científicas face a programas de pesquisa "exóticos". Ao estabelecer similaridades entre mito e ciência, o autor nega que a última apresente um "ceticismo essencial", imputando a ela "reações de tabu" e um "dogmatismo" característicos do primeiro. Conclui Feyerabend que:

"A ciência não está preparada para fazer do pluralismo teorético o fundamento da pesquisa. Newton dominou por mais de 150 anos; Einstein introduziu, por curto espaço de tempo, um ponto de vista mais liberal, mas viu-se sucedido pela Interpretação de Copenhague. As semelhanças entre ciência e mito são inegavelmente de espantar.

\footnotetext{
${ }^{54}$ Com isso gostaríamos de salientar que outras propostas epistemológicas negam algumas, senão todas essas idéias (incomensurabilidade, ruptura etc).
} 
Os campos estão, entretanto, ainda mais estreitamente relacionados. $O$ dogmatismo pesado a que fiz alusão não é apenas um fato, mas desempenha também importantíssima função. Sem ele seria impossível a ciência.'

Nesse ponto, Feyerabend cita o trabalho de Kuhn, de cujas idéias aproxima-se no que se refere a uma caracterização do fazer científico, a uma descrição de sua prática cotidiana e comum. Sua extensa análise dos trabalhos de Galileu não contradiz essa caracterização, uma vez que, para Feyerabend, Galileu não procedeu como a maioria dos cientistas acredita proceder. Se, por um lado, Galileu não representa um personagem típico da prática conservadora da ciência, também essa prática não se baseia em princípios tão "racionais" como os próprios cientistas parecem crer.

Galileu representa, na concepção de Kuhn, um "personagem de transição", um dos protagonistas de uma revolução científica que instaura um novo paradigma. A ciência extraordinária que desenvolve representa um período, na epistemologia kuhniana, onde há flexibilização das regras, oportunidade de desenvolvimento de novas teorias, questionamentos de princípios básicos etc. Essa "proliferação" é, para Kuhn, um sintoma de crise, como afirmamos anteriormente:

"Mas essa invenção de alternativas é precisamente o que os cientistas raro empreendem, exceto durante o período pré-paradigmático do desenvolvimento de sua ciência e em ocasiões muito especiais de sua evolução subseqüente. Enquanto os instrumentos proporcionados por um paradigma continuam capazes de resolver os problemas que este define, a ciência move-se com maior rapidez e aprofunda-se ainda mais através da utilização confiante desses instrumentos. A razão é clara. Na manufatura, como na ciência - a produção de noyos instrumentos é uma extravagância reservada para as ocasiões que o exigem.' 56

Já para Feyerabend, isso deveria ser o corrente em ciência, e não o extraordinário. O único princípio deve ser o "tudo vale", e a proliferação de teorias é benéfica à ciência, intensifica o seu progresso. Isso não significa que, para Kuhn, a "proliferação de teorias" seja "maléfica" à ciência, uma vez que atitude semelhante é prerrogativa tanto da fase pré-paradigmática quanto dos períodos revolucionários. Mas Kuhn acredita que seja exclusiva a essas fases. Nesse sentido (e aqui adentramos no segundo ponto de comparação), sua visão de progresso é contraditória com a de Feyerabend, se as

\footnotetext{
${ }^{55}$ Ibid., p. 452.

${ }^{56}$ KUHN, T. S. - Op. cit., p. 105.
} 
tomarmos como uma prescrição do fazer científico. O progresso para Feyerabend intensifica-se por outras vias, delineadas a partir de seu anarquismo epistemológico.

Embora o enfoque de Bachelard seja o de uma "psicologia do conhecimento científico", no sentido de que não enfatiza tanto as influências sociais, culturais etc no fazer da ciência, suas concepções aproximam-se das de Feyerabend em muitos aspectos. Já foi explicitada aqui, por exemplo, a posição bachelardiana de fazer avançar a ciência a partir do ataque da ciência já constituída. Isso não representa uma idéia de "refutacionismo", pois Bachelard a afirma no contexto da defesa de uma posição racionalista frente a um realismo inicial. Esse "ataque" seria, portanto, um ataque racional, representado em parte pela noção de vetor epistemológico, pela idéia de "realização do racional". Feyerabend, no bojo de sua discussão acerca da falaciosa distinção entre termos observacionais e termos teóricos, lembra-nos as posições de Bachelard contra o realismo e o racionalismo absolutos:

"Enfim, descobrimos que o aprendizado não se desenvolve da observação para a teoria, mas sempre envolve ambos esses elementos. A experiência aparece acompanhada de pressupostos teóricos e não antes deles; e a experiência sem teoriq é tão incompreensivel quanto (supostamente) a teoria sem experiência (...).

É claro que Feyerabend procura "solapar a autoridade da Razão", mas "participa do jogo da Razão" para atingir seus objetivos. Ao defender uma "metodologia pluralista" e a comparação de "idéias" antes com outras "idéias" do que com a experiência, o autor aponta para uma concepção de conhecimento que apresenta uma grande interface com aquilo que está presente em Bachelard. Nos diz Feyerabend:

"O conhecimento, concebido segundo essas linhas, não é uma série de teorias coerentes, a convergir para uma doutrina ideal; não é um gradual aproximar-se da verdade. É, antes, um oceano de alternativas mutuamente incompatíveis (e, talvez, até mesmo incomensuráveis), onde cada teoria singular, cada conto de fadas, cada mito que seja parte do todo força as demais partes a manterem articulação maior, fazendo com que todas concorram, atrqués desse processo de competição, para o desenvolvimento de nossa consciência."

As diversas doutrinas filosóficas convivendo no espírito científico com diferentes níveis de intensidade, conforme o conceito, a época e a cultura particulares, não

\footnotetext{
${ }^{57}$ FEYERABEND, P. - Op. cit., p. 262-263.

${ }^{58}$ Ibid., p. 40-41.
} 
representariam "alternativas mutuamente incompatíveis" que competem "para o desenvolvimento de nossa consciência”? Sejamos, contudo, cautelosos: Feyerabend refere-se aqui a uma competição entre teorias, entre "visões de mundo" (poderíamos falar em paradigmas?). Não há uma correspondência direta com as "doutrinas filosóficas" de Bachelard. Novamente estamos diante de uma profunda questão, para a qual já chamamos a atenção. Seria, quem sabe, um trabalho interessante investigar em que medida a perspectiva colocada por Feyerabend para a ciência encontra, na "psicologia do conhecimento científico" de Bachelard, sua guarida.

A última citação revela também um forte vínculo entre as noções de progresso em Kuhn, Bachelard e Feyerabend: a negação desse processo como um acúmulo de conhecimentos em direção à verdade. O acúmulo inexiste devido às rupturas e à incomensurabilidade (e aqui adentramos nos dois últimos pontos).

A noção de incomensurabilidade é exaustivamente trabalhada por Feyerabend, que procura deixar claro que (como dissemos) a continuidade das relações formais entre teorias não implica a continuidade no plano interpretativo ou ontológico. Torna-se portanto evidente como esse referencial encara a ruptura de maneira profunda.

Ao afirmar que o "desenvolvimento da percepção e do pensamento, no indivíduo, atravessa estágios que são mutuamente incomensuráveis", Feyerabend corrobora a existência não apenas da incomensurabilidade, mas de um processo do tipo rupturacontinuidade na ciência e no indivíduo. Nesse ponto suas conclusões remetem-nos quase que imediatamente a Bachelard e sua noção de "perfil epistemológico".

O nosso referencial epistemológico viu-se, ao longo desse capítulo, ampliado e problematizado a partir de outras concepções. Às questões primeiras oferecemos respostas que, como boas respostas, trazem em si um conjunto de novos questionamentos. A "realidade epistemológica" complica-se, porquanto a ciência é também complexa.

Apontaremos a seguir algumas conclusões que, como boas conclusões, são apenas momentâneas, pois deixam uma série de problemas abertos. Servir-nos-ão, entretanto, para estabelecer, entre outras coisas, a importância dessa discussão epistemológica no âmbito da educação, preocupação do capítulo seguinte.

\section{I.6. CONCLUSÕES}


As condições externas que os fatos da experiência colocam [diante do cientista] não lhe permitem, ao erigir seu mundo conceitual, que ele se prenda em demasia a um dado sistema epistemológico. Em conseqüência, o cientista aparecerá, aos olhos do epistemologista que se prende a um sistema, como um oportunista inescrupuloso (...)

Albert Einstein 59

A) As discussões precedentes evidenciam:

$1^{\circ}$ ) A importância da história da ciência para a epistemologia, em geral, $\underline{e}$ para o ensino de ciências, em particular.

Quanto ao primeiro ponto, os três referenciais epistemológicos trabalhados por nós buscam, na história da ciência, fundamentar as suas posições. Depreende-se disso não apenas a importância desse estudo e seu papel na articulação de idéias no plano epistemológico, mas a riqueza do material histórico, que permite diversas leituras. Certamente há outras concepções que menor importância dão à história. Porém, como nosso desejo era não somente o de apresentar diferentes visões, mas sim delinear uma concepção de ciência e de seu desenvolvimento a partir delas, tornou-se necessário fazer uma escolha. Uma escolha que consideramos pluralista e não-dogmática, é verdade, mas que deixou de lado outras visões, que partem de outros princípios (voltaremos a isso adiante). Em resumo: evidenciamos a importância da história da ciência porque fizemos uso de epistemologias que a evidenciam. Por outro lado, concepções ahistóricas nos levariam a uma imagem da ciência que não compartilhamos. $O$ fato de existirem essas outras concepções apenas evidencia, ainda mais, a importância do estudo histórico.

Com relação ao ensino de ciências, a questão é mais complexa. Uma concepção epistemológica que revele a ciência como um processo histórico de natureza nãocumulativa, como um saber em construção, mas não rumo à "verdade", certamente não pode vincular-se a uma educação a-histórica. Subjazem necessariamente ao ensino de ciências certas concepções epistemológicas, ainda que isso não esteja claro, muitas

${ }^{59}$ Apud FEYERABEND, P. - Op. cit., p. 20. 
vezes. No capítulo seguinte apontaremos como um ensino a-histórico pode vincular-se a uma concepção metafísica de conhecimento.

Para finalizar esse primeiro ponto, vejamos algumas colocações de Kuhn, Bachelard e Feyerabend que nos mostram a importância da história da ciência. Na introdução da Estrutura, Kuhn afirma que:

\begin{abstract}
"Se a História fosse vista como um repositório para algo mais do que anedotas ou cronologias, poderia produzir uma transformação decisiva na imagem de ciência que atualmente nos domina. Mesmo os próprios cientistas têm haurido essa imagem principalmente no estudo das realizações científicas acabadas, tal como estão registradas nos clássicos e, mais recentemente, nos manuais que cada nova geração utiliza para aprender seu ofício. Contudo, o objetivo de tais livros é inevitavelmente persuasivo e pedagógico; um conceito de ciência deles haurido terá tantas probabilidades de assemelhar-se ao empreendimento que os produziu como a imagem de umacultura nacional obtida através de um folheto turístico ou um manual de línguas.",60
\end{abstract}

Ao fundamentar sua filosofia do não, Bachelard comenta a importância histórica para a compreensão do átomo:

"Não nos parece com efeito que se possa compreender o átomo da física moderna sem evocar a história das suas imagens, sem retomar as formas realistas e as formas racionais, sem lhe explicitar o perfil epistemológico. A história dos diversos esquemas é neste caso um plano pedagógico inelutável.'

Feyerabend, ao defender a manutenção de teorias com baixo conteúdo empírico, e criticar as posições a favor de uma metodologia rígida, que as excluiria, declara que:

"É surpreendente a relutância com que filósofos e cientistas adaptam suas concepções gerais a uma atividade em que já estão presentes aquelas teorias falhas.(...) Essa relutância, essa resistência psicológica é que faz necessário combinar o argumento abstrato com o malho da história. O argumento abstrato é imprescindivel porque imprime sentido a nossa reflexão. A história, entretanto, é também imprescindízel, ao menos no atual estágio da filosofia, porque dá força a nossos argumentos.

$2^{\circ}$ ) A importância do estudo epistemológico para a formação dos professores, sejam eles cientistas, pesquisadores em ensino de ciências, ou educadores atuantes nos diversos níveis de ensino.

\footnotetext{
${ }^{60}$ KUHN, T. S. - Op. cit., p. 19-20. Essa é uma leitura possível das colocações de Kuhn. Voltaremos a isso no capítulo seguinte.

${ }^{61}$ BACHELARD, G. - A Filosofia do Não, $5^{\text {a }}$ edição, 1991, p. 131.

${ }^{62}$ FEYERABEND, P. - Op. cit., p. 244.
} 
Esperamos já haver evidenciado, no item anterior, a existência de um vínculo (que será retomado no capítulo seguinte) entre "concepção epistemológica" e "prática educacional", no que se refere à ciência. ${ }^{63}$ Tanto o cientista quanto o educador em geral devem alertar-se para isso, do que depende fundamentalmente a imagem de ciência com a qual trabalham e influenciam outras pessoas. Com isso gostaríamos de ressaltar que, na ausência de tal tipo de discussão epistemológica nos cursos de formação de cientistas e educadores, corre-se o risco de uma educação científica "vazia", onde convivem várias concepções de ciência sem que se tenha consciência disso. Apresentar diversas concepções epistemológicas é permitir olhares diferenciados sobre a ciência, algo essencial numa perspectiva educacional não-dogmática.

Nesse sentido, poderiam objetar-nos acerca da ausência de outras visões epistemológicas no presente trabalho. Embora as consideremos importantes na formação de cientistas e educadores, como exposto acima, acreditamos já ter justificado o porquê de nossa escolha. Certamente que nomes como Francis Bacon, David Hume, Karl Popper, Imre Lakatos, entre outros, devem constar do estudo epistemológico ao qual nos referimos. Difícil seria supor o contrário, uma vez que a o trabalho de Kuhn, Bachelard e Feyerabend aflora, freqüentemente, a partir de críticas a muitos desses autores.

Finalizaremos esse ponto com uma citação da tese de doutoramento de João Zanetic, que apresenta várias epistemologias e defende que elas sejam discutidas nos cursos de licenciatura em ciências exatas:

"O professor de física do segundo grau precisa estar ciente de que o "método científico" não se resume àquele conjunto de regras bem estabelecidas, que existem diferentes concepções que buscam explicar o processo de desenvolvimento das teorias e que algumas dessas concepções são antagônicas entre si. Estas diferentes visões epistemológicas, bem como a "redescoberta" do discurso dialético, colaboram no sentido de oferecer uma base filóf́fica da chamada "cultura científica", da recuperação da física como cultura."

B) As concepções de Kuhn, Bachelard e Feyerabend são "incomensuráveis"? Que "posicionamento epistemológico" é possível ao final dessa apresentação? Consideraremos três alternativas a seguir:

\footnotetext{
${ }^{63}$ Esse vínculo tem uma natureza mais geral, aplicando-se a outras formas de conhecimento. O nosso objeto de estudo, entretanto, é a ciência.
} 
$1^{\text {a }) ~ U m a ~ " a b o r d a g e m ~ k u h n i a n a " ~ d a ~ q u e s t a ̃ o ~ p o d e r i a ~ l e v a r-n o s, ~ q u e m ~ s a b e, ~ a ~ a d o t a r ~ u m a ~}$ concepção epistemológica única, um "paradigma epistemológico". Isso, entretanto, não nos parece interessante, face não apenas às profundas relações que estabelecemos entre as diversas visões, mas à importância que damos a todas elas (e às demais) na análise da natureza do empreendimento científico e do complexo desenvolvimento histórico da ciência.

Poderíamos, ainda dentro dessa abordagem, acreditar estarmos vivendo uma "crise epistemológica", na qual diversas epistemologias concorrem em busca de "adeptos". Isso certamente seria possível, mas a complexidade do conhecimento científico sugerenos uma abordagem mais ampla, e é nesse sentido que, desde o início, procuramos assumir o referencial epistemológico de Thomas Kuhn de um ponto de vista nãodogmático.

$2^{\text {a }) ~ U m a ~ " a b o r d a g e m ~ f e y e r a b e n d i a n a " ~ t a l v e z ~ s i g n i f i c a s s e ~ a ~ p u r a ~ e ~ s i m p l e s ~ a d o c ̧ a ̃ o ~ d o ~}$ "anarquismo epistemológico" no âmbito da própria epistemologia, ou seja, algo como uma "proliferação de teorias" nesse terreno. O "tudo vale" epistemológico seria uma visão suficientemente aberta e libertária, além de "benéfica" ao "progresso epistemológico”. Consideramos uma posição louvável e interessante.

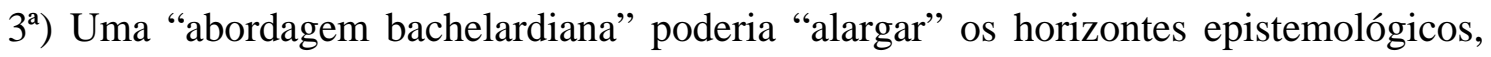
numa interface com a posição anterior. Bachelard sugere uma "epistemologia nãocartesiana" no mesmo sentido de "alargamento filosófico" cujas bases estabelece com sua "filosofia do não".

Algo parecido com a noção de "perfil epistemológico" poderia ser pensada com relação ao espírito do epistemólogo, que se utiliza de diversas epistemologias nas diversas leituras que faz do fazer científico. Haveria também intensidades de utilização dessas epistemologias. Há, sem dúvida, uma série de questões profundas a serem colocadas: poder-se-ia falar em uma hierarquia para as epistemologias? E em progresso filosófico? Como compatibilizar essa idéia com a noção de "perfil" tal como colocada pelo autor, uma vez que uma epistemologia é algo amplo, e o "perfil" bachelardiano refere-se a um conceito particular, numa determinada cultura? Significaria isso

\footnotetext{
${ }^{64}$ ZANETIC, J. - Física também é Cultura (Tese de Doutoramento), FEUSP, 1989, p. 90.
} 
transportar elementos do "anarquismo epistemológico" para a "psicologia do espírito do epistemólogo"?

Não poderíamos pretender responder a essas questões tão complexas. Entretanto, essa abordagem parece-nos garantir uma diversidade fundamental, que nos permite esclarecer as diversas "faces" da ciência, parafraseando novamente Bachelard. Porque quando pensamos a prática cotidiana da ciência, por exemplo, acentuam-se características do referencial epistemológico de Kuhn (caráter descritivo: o "êe" da ciência), ao passo que algumas concepções de Feyerabend preponderam em nosso pensar quando está em jogo uma prescrição (o "deve ser" da ciência). Estejamos atentos, contudo, àquilo que coloca Feyerabend a esse respeito quando discute a falaciosa distinção entre "contexto da descoberta" e "contexto da justificação":

"O progresso, repitamos, só será alcançado se a distinção entre o ser $e$ o deve ser for encarada como recurso temporário e não como linha divisória fundamental., 65

De qualquer modo, esperamos ter apontado algumas relações que, de maneira

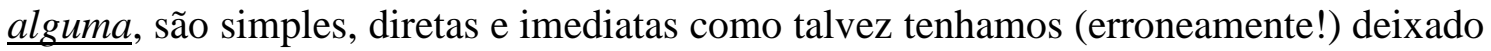
transparecer. Seria necessário aprofundá-las, o que transcende o esforço desse trabalho.

A importância até aqui foi a de delinear uma concepção de ciência e de progresso científico e, como conseqüência, ressaltar a importância do estudo epistemológico para a formação profissional do cientista, do pesquisador em ensino e do educador. Sob esse aspecto, esse foi um caminho possível. Haveriam, certamente, outros....

\footnotetext{
${ }^{65}$ FEYERABEND, P. - Op. cit., p. 262.
} 


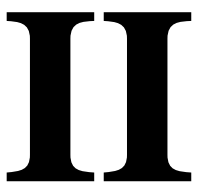

Mestre não é quem sempre ensina, mas quem de repente aprende.

João Guimarães Rosa (em "Grande Sertão: Veredas") 


\section{CONSIDERAÇÕES EDUCACIONAIS}

A educação é uma atividade essencialmente conservadora. Não obstante, é inerente a ela um potencial transformador: quando pensamos em transformação social, política ou cultural, por exemplo, remetemo-nos quase que imediatamente à importância da educação para esses processos.

Não seguiremos exatamente o mesmo caminho anterior para desvelar o falso paradoxo contido nas afirmações acima. Procuraremos evidenciar inicialmente em que medida o ensino de ciências (particularmente o ensino de física, objeto de nosso estudo) tradicionalmente presente em nossas escolas relaciona-se a uma concepção de conhecimento científico que difere radicalmente daquela delineada no capítulo anterior. Uma crítica a tal concepção, que subjaz ao ensino tradicional, revelar-se-á ao mesmo tempo uma crítica ao caráter dogmático da educação, em geral, e da educação científica, em particular. O paradoxo desfaz-se quando pensamos em uma prática educativa que se baseie numa concepção de conhecimento científico que possa conter os elementos epistemológicos discutidos anteriormente. Esses elementos encontram abrigo numa concepção dialética do conhecimento.

Dentro dessa concepção apontaremos a importância da história da ciência para o ensino de física, bem como a necessidade de buscarmos práticas interdisciplinares que invertam a tendência massificadora, doutrinadora, dogmática e compartimentalizada presente na educação tradicional.

\section{II.1. UMA CONCEPÇÃO DE EDUCAÇÃO ?}

“(...) como estudantes, éramos obrigados a acumular essas noções em nossas mentes para os exames. Esse tipo de coerção tinha (para mim) um efeito frustante. Depois de ter passado nos exames finais, passei um ano inteiro durante o qual qualquer consideração sobre problemas científicos me era extremamente desagradável. Porém, devo dizer que na Suiça essa coerção era bem mais branda do que em outros países, onde a verdadeira criação científica é completamente sufocada. (...) Na verdade, é quase um milagre que os métodos modernos de instrução não tenham exterminado completamente a sagrada sede de saber, pois essa planta frágil da curiosidade científica necessita, além de estímulo, especialmente de liberdade; sem ela, fenece e morre. É um grave erro supor que a 
satisfação de obşrvar e pesquisar pode ser promovida por meio da coerção e da noção do dever. 1

Como aponta João Zanetic , embora essa contundente crítica de Einstein refira-se aos cursos que fazia na universidade, ela bem que poderia ser dirigida à quase totalidade das experiências em educação. Seu caráter extremamente atual revela-nos o quanto a educação envolve "coerção", sendo essa uma manifestação de uma visão autoritária, dogmática e doutrinária da prática educativa.

Salientamos, no capítulo precedente, o caráter conservador inerente à prática científica. Certamente há um forte vínculo entre concepção de ciência, educação científica e o fazer científico. A prática da ciência normal vincula-se a uma educação científica que transcende esse caráter conservador (no sentido de uma "permanência cultural”), assumindo muitas vezes uma posição essencialmente dogmática:

"Trata-se certamente de uma educação rígida e estreita, mais do que qualquer outra, provavelmente - com a possível exceção da teologia ortodoxa. ${ }^{, B}$

Como já dissemos, pode-se fazer uma leitura da obra de Kuhn no sentido de uma "prescrição". Nesse caso, haveria uma necessidade de tal dogmatismo pedagógico para o progresso científico. O futuro cientista estaria "perdendo tempo" caso se voltasse para questões como a história de sua disciplina, ou para aspectos filosóficos ou epistemológicos. A "solução de quebra-cabeças" requer mais uma espécie de "treinamento" do que propriamente uma "educação".

Essa situação explicita-se através dos chamados "manuais científicos", objetos da análise de Kuhn. Esses "manuais", que seriam basicamente os livros didáticos voltados ao ensino superior, são veículos de transmissão do paradigma, destinados a perpetuá-lo. Para esse intuito, a eficiência é alcançada através de uma educação a-histórica, excessivamente formal, onde o conhecimento científico é apresentado como algo monolítico. Há uma "linearidade" que não permite ao estudante perceber as rupturas e contradições pelas quais passou o desenvolvimento histórico do conhecimento científico. Ele é "limpo", "esterilizado", "asséptico". Carece de humanidade, e ajuda a perpetuar uma imagem "neutra" da ciência e do cientista, além de uma idéia de que o

\footnotetext{
${ }^{1}$ EINSTEIN, A. - Notas autobiográficas, $5^{\text {a }}$ edição, 1982, p. 25-26.

${ }^{2}$ ZANETIC, J. - Física também é Cultura (Tese de Doutoramento), FEUSP, 1989, p. 44.

${ }^{3}$ KUHN, T. S. - A Estrutura das Revoluções Científicas, $2^{\mathrm{a}}$ edição, 1987, p. 208.
} 
conhecimento construído é resultado de um acúmulo gradual, onde cada geração "retoca" o saber de gerações anteriores. Como afirma Kuhn:

"É característica dos manuais científicos conterem apenas um pouco de história, seja um capítulo introdutório, seja, como acontece mais freqüentemente, em referências dispersas aos grandes heróis de uma época anterior. (...) Por razões a mesmo tempo óbvias e muito funcionais, os manuais científicos (e muitas das antigas histórias da ciência) referem-se somente àquelas partes do trabalho de antigos cientistas que podem facilmente ser consideradas como contribuições ao enunciado e à solução dos problemas apresentados pelo paradigma dos manuais."

"A depreciação dos fatos históricos está profunda e provavelmente funcionalmente enraizada na ideologia da profissão científica, a mesma profissão que atribui o mais alto valor possível a detalhes fatuais de outras espécies.

Embora explicite a "funcionalidade" dessa pedagogia, o autor também afirma que não é da maneira sugerida pelos "manuais" que a ciência desenvolve-se. Mais adiante, Kuhn aponta-nos a distorção que é fruto de tal educação:

"A educação científica não possui algo equivalente ao museu de arte ou a biblioteca de clássicos. Daí decorre, em alguns casos, uma distorção drástica da percepção que o cientista possui do passado de sua disciplina.'

Como esperamos haver deixado claro, tomamos essa análise de Kuhn como uma crítica à educação científica. Nada impede que o progresso científico possa intensificarse por meio de uma educação mais humanista e menos dogmática, que apresente o fazer científico em toda sua complexidade histórica e, portanto, inacabado.

A crítica aos "manuais" pode, quase sem ressalvas, ser estendida aos livros didáticos destinados ao ensino médio ${ }^{6}$. Esses livros, voltados essencialmente para os exames vestibulares, reproduzem em geral uma visão de ciência, e particularmente da física, distanciada da realidade histórica. Inserem-se num contexto educativo deficiente, que mais prejudica do que auxilia, na construção de uma visão de ciência nãodogmática.

\footnotetext{
${ }^{4}$ Ibid., p. 175-176.

${ }^{5}$ Ibid., p. 209.

${ }^{6}$ Segundo a nova Lei de Diretrizes e Bases (LDB) da Educação, o antigo "ensino de segundo grau" passou a chamar-se "ensino médio", e denomina-se agora "ensino fundamental" o antigo "primário" e "primeiro grau".
} 
Zanetic utiliza o adjetivo "danoso" com referência ao ensino de física ministrado em nossas escolas. Dentre suas principais características, estariam

- Operacionalização pobre dos conceitos e leis da física clássica, uma vez que se busca um mero "treinamento" no algoritmo da física, através da resolução de exercíciospadrão que pouco auxiliam na compreensão dos conceitos. É o "formulismo";

- Supressão da prática experimental, do laboratório didático;

- Pouca ou nenhuma discussão referente a aspectos metodológicos em física, o que leva a uma visão do cientista ou como um ser "iluminado" ou como um seguidor de um pretenso "método científico" único e infalível;

- Ausência da história da física, tanto internalista quanto externalista;

- Apresentação da física como um ramo do conhecimento "neutro", desvinculado do cotidiano, e apolítico;

- Ausência da física moderna (mecânica quântica e teoria da relatividade, basicamente).

Tudo isso caracteriza o que Zanetic chama de "física escolar". Por uma série de motivos, tais como: os baixos salários dos professores, que os obrigam a uma jornada excessivamente longa de trabalho; a corrida para os exames vestibulares; a política editorial de livros didáticos, entre muitos outros, todos esses problemas do ensino de física levantados acima acabam perpetuando-se, ainda que diante de várias tentativas isoladas ou, até mesmo, de vários projetos coletivos voltados ao ensino médio de física Continua válida a conclusão a que chegou Zanetic em 1989:

"Caricaturando um pouco toda essa situação, particularmente no que diz respeito à escola pública, eu diria que esses e outros motivos acabam convergindo num só: os professores por falta de tempo, disposição e motivação acabam optando pelos livros didáticos que nasceram nas aulas de cursinhos pois, de um lado, já têm a destinação certa (preparar para o vestibular) e, de outro, facilitam o preparo das aulas já que apresentam um resumo "apropriado" da "teoria em física" e uma lista de exercícios e problemas típicos de exames que manterão os alunos ocupadgs por muito tempo. E assim, a física "escolar" passa a ser a física "vestibular","

\footnotetext{
${ }^{7}$ ZANETIC, J. - Op. cit., p. 15-17.

${ }^{8}$ No capítulo 6 de sua tese, Zanetic, entre outras coisas, analisa uma série desses projetos (tanto brasileiros quanto estrangeiros), tais como: PSSC, Harvard, FAI, PBEF, PEF.

${ }^{9}$ Ibid., p. 194.
} 
Mas tanto os conteúdos quanto as metodologias empregadas tradicionalmente no ensino de física vinculam-se a uma certa concepção de conhecimento. Armando A. Simões busca caracterizá-la, denominando-a concepção metafísica do conhecimento, em sua dissertação de mestrado intitulada A Concepção Dialética do Conhecimento e o Ensino de Físicd 10 . Chama o autor nossa atenção para o fato de que o termo "metafísica" assume diversas acepções na filosofia, mas será adotado no sentido da "metafísica tradicional específica, que dogmaticamente pretende atingir a natureza profunda do ser (por exemplo, a chamada "ciência primeira" de Aristóteles e dos escolásticos)", como colocam Ludovico Geymonat e Giulio Giorello em sua obra As Razões da Ciêncid 11 .

De tal concepção metafísica do conhecimento resulta uma tradição pedagógica fundada na idéia de transmissão de conteúdos, na qual o "saber acumulado" é transmitido da fonte do saber (o professor) até a fonte da ignorância (o aluno). Essa idéia é a base do sentido atribuído por Paulo Freire à palavra "extensão" em sua obra Extensão ou Comunicação?, caracterizando a prática de técnicos agrônomos junto a camponeses chilenos. Contrapõe-se à "transmissão"-“extensão" uma "educação libertadora":

“Ao contrário, educar e educar-se, na prática da liberdade, é tarefa daqueles que sabem que pouco sabem - por isto sabem que sabem algo e podem assim chegar a saber mais - em diálogo com aqueles que, quase sempre, pensam que nada sabem, para que estes, transformando seu pensqr que nada sabem em saber que pouco sabem, possam igualmente saber mais.'

Quais as características da "concepção metafísica do conhecimento"? A seguir procuraremos apontá-las, resumidamente, a partir do trabalho de Simões.

Para a metafísica, conhecer significa questionar-se sobre a "essência" das coisas, o que elas "são". Diante de uma pergunta como "o que é o vento?", busca-se uma definição: "o vento é o ar em movimento":

"A essência do objeto determina ao mesmo tempo o seu conhecimento e a sua existência. No exemplo anterior o ar em movimento determinaria a existência do

${ }^{10}$ SIMÕES, A. A. - A Concepção Dialética do Conhecimento e o Ensino de Física (Dissertação de Mestrado), IFUSP/FEUSP, 1994. Armando esclarece-nos que a expressão "concepção metafísica do conhecimento" foi extraída da obra Dialética do Conhecimento, de Caio Prado Jr..

${ }^{11}$ Apud SIMÕES, A. A. - Op. cit., p. 45.

${ }^{12}$ FREIRE, P. - Extensão ou Comunicação?, $2^{\mathrm{a}}$ edição, 1975, p. 25. 
vento, assim como a ausência dessa essência (o ar em movimento) implicaria na não existência do vento. $O$ conhecimento de algo seria portanto, segundo essa tradição, a presença, na esfera do pensamento, daquele conteúdo que, existindo faz comque a coisa exista, e que na sua ausência faz com que a coisa não exista.

A própria pergunta pressupõe uma resposta do tipo metafísica, na qual o conceito de "vento" transforma-se (paradoxalmente!) em algo estático. "O que é o átomo?" seria certamente uma pergunta mais difícil de ser respondida dentro dessa visão. De passagem, lembremos de Bachelard, quando afirma que o átomo da física moderna é a soma das críticas históricas a que foi submetido, como dissemos no capítulo precedente.

Voltando à metafísica, notamos que ela dicotomiza a realidade, promovendo uma rígida separação entre o sujeito e o objeto, entre o pensamento e o mundo. E, ao buscar a "essência" das coisas, identifica-se com a noção de "verdade". Essa, uma "propriedade do ente", torna o conhecimento assim constituído "implicitamente correto, verdadeiro, absoluto,"14, uma vez que esse resulta da apropriação, por parte do sujeito, da "essência" - "verdade" do objeto. Conclui parcialmente Simões que:

"O conhecimento, portanto, na perspectiva da metafísica é a-histórico. Porque reside já na realidade, seja esta uma realidade divina ("ideal”), seja uma realidade terrena ("material"), esse conhecimento se revela absolutamente, com todo o seu acabamento, em toda sua plenitude. Ele já está dado, só precisamos descobri-lo, revelá-lo. Desse modo a metafísica se instala também na concepção acumulativa progressiva do conhecimento, não como rompimento atrqués de novos conceitos, mas por acréscimos sempre maiores de novos elementos." 15

No plano pedagógico, revela-se a metafísica através de uma pedagogia centrada no professor, que procura realizar uma transposição do conhecimento para o aluno, repetindo de certo modo o processo de aquisição desse conhecimento, que é também uma transposição ("essência" do objeto $\rightarrow$ esfera do pensamento).

Nesse processo, o aluno-aprendiz é mero "receptáculo" de informações. Paulo Freire critica duramente essa pedagogia tradicional, que denomina de "educação bancária". O educando (como chama Freire) "recebe" o conhecimento que lhe é "depositado", sem agir sobre o objeto desse conhecimento. A educação passa a ser treinamento, doutrinação (lembremos de Kuhn e da formação do cientista).

\footnotetext{
${ }^{13}$ SIMÕES, A. A. - Op. cit., p. 46.

${ }^{14}$ Ibid., p. 53.

${ }^{15}$ Ibid., p. 54.
} 
Contrapõe-se a essa concepção, apresentando-se como uma alternativa a ela, uma "concepção dialética do conhecimento, que o termo "dialética" assumiu diversas acepções ao longo da história, mas vinculadas sempre pela idéia de dinamismo. O autor passa a empregá-lo como um "modo de pensamento, que reconhece o devir como a única permanência no Universo (totalidade em processo)"17. Dentro dessa concepção, o conhecimento é construído pelo indivíduo que pensa, num processo caracterizado pelo dinamismo e pela historicidade, no qual surgem representações da realidade, que são sintetizadas sob a forma de conceitos que se inter-relacionam:

“As relações são constitutivas dos objetos e fenômenos, sendo pois o modo como estes aspectos da realidade se dispõem e compõem no espaço e no tempo. De fato aquilo que para a metafísica constituía um individual absoluto, uma essência, a dialética vai desdobrar, redescobrir numa teia de relações. Todo singular é para a dialética plural, pois sua singularidade ́́ uma "síntese de múltiplas determinações", uma "unidade na diversidade".

O conhecimento, portanto, não é algo acabado, estático, mas em constante transformação. Sua principal característica é o movimento, o devir. A dialética irá pressupor a ação do ser humano transformando o meio em que vive: o homem como agente da cultura, como sujeito da realidade que investiga.

Mas a ação do homem modifica a realidade, transforma o objeto dessa ação, que por sua vez retorna a ele, homem, transformando-o. Nesse contexto, relativiza-se a noção de "verdade", atribuindo-se a ela o movimento característico do pensar dialético:

"Enquanto a Metafísica responde à pergunta sobre a verdade do conhecimento com "é” ou "não é”, a Dialética responde com "está sendo" ou "pode ser diferente"."

"Em suma, o critério da verdade se encontra, pensando-se dialeticamente, nas relações do conhecimento com a prática humana. Sendo esta última histórica, assim também o será o conhecimento oriundo dessa prática e o seu critério de verdade." 19

Essa "concepção dialética do conhecimento" tem implicações no plano pedagógico, uma vez que fundamenta não apenas possíveis concepções acerca da

\footnotetext{
${ }^{16}$ Novamente aqui, esclarece-nos Armando que a expressão "concepção dialética do conhecimento" foi extraída da obra Dialética do Conhecimento, de Caio Prado Jr..

${ }^{17}$ Ibid., p. 68.

${ }^{18}$ Ibid., p. 71.

${ }^{19}$ Ibid., p. 83 e 86.
} 
ciência, como também concepções possíveis acerca do ensino de ciências, tendo reflexos sobre as metodologias de ensino.

Simões aponta como a proposta pedagógica de Paulo Freire tem vínculos com uma teoria dialética do conhecimento. À proposta freireana de educação subjaz a possibilidade de concretizar na escola a perspectiva colocada pela dialética no campo epistemológico. Aliás, Freire nos fala mais propriamente de uma gnosiologia, ao invés de uma epistemologia, uma vez que sua preocupação é a construção do conhecimento pelo sujeito, e a relação desse sujeito com o objeto de seu conhecimento.

Em Extensão ou Comunicação? o educador se pergunta:

“(...) será o ato de conhecer aquele através do qual um sujeito, transformado em objeto, recebe pacientemente um conteúdo de outro? Pode este conteúdo, que é conhecimento de, ser "tratado" como se fosse algo estático? Estará qu não submetendo o conhecimento a condicionamentos histórico-sociológicos?'

O "ato de conhecer" exige, para Freire, uma ação transformadora do sujeito sobre a realidade. Conhecer é uma busca que envolve invenção e reinvenção, e uma reflexão crítica sobre o próprio ato de conhecer. Tudo isso o afasta da idéia de sujeito como "espectador", como receptor passivo do conhecimento que lhe é "transmitido"; da concepção metafísica do conhecimento. Na primeira parte do último capítulo de sua obra, nos diz Freire:

"A educação é comunicação, é diálogo, na medida em que não é a transferência de saber, mas um encontro de sujeitos interlocutores que buscam a significação dos significados."

"Este algo, que mediatiza os sujeitos interlocutores, pode ser tanto um fato concreto (a semeadura e suas técnicas, por exemplo), como um teorema matemático.'

\footnotetext{
${ }^{20}$ No Dicionário de Filosofia de José F. Mora, os termos epistemologia e gnosiologia são considerados sinônimos, significando "teoria do conhecimento". Afirma-se que "epistemologia" foi introduzido para designar a "teoria do conhecimento científico", mas vem sendo usado em quase todos os casos. MORA, J. F. - Dicionário de Filosofia, 1994, p. 216 e 318-319. Já André Lalande apresenta a "epistemologia" como "o estudo crítico dos princípios, das hipóteses e dos resultados das diversas ciências, destinado a determinar sua origem lógica (não psicológica), o seu valor e a sua importância objetiva", enquanto "gnosiologia" "aplicar-se-ia bem pela sua etimologia à análise reflexiva do ato ou da faculdade de conhecer". LALANDE, A. - Vocabulário técnico e crítico da filosofia, $10^{a}$ edição, s/d, p. 370 e 530.0 termo "gnosiologia" parece-nos ter, portanto, um significado mais geral, transcendendo o campo "científico" e englobando a relação sujeito-objeto na reflexão sobre o ato de conhecer.

${ }^{21}$ FREIRE, P. - Op. cit., p. 26.

${ }^{22}$ Ibid., p. 69.
} 
Compreendendo o conhecimento como algo não estático, os conteúdos precisam ser "problematizados":

"A tarefa do educador, então, é a de problematizar aos educandos o conteúdo que os mediatiza, e não a de dissertar sobre ele, de dá-lo, de estendê-lo, de entregá-lo, como se se tratasse de algo já feito, elaborado, acabado, terminado.

Neste ato de problematizar os educandos, ele se encontra igualmente problematizado." 23

Nessa perspectiva, a interdisciplinaridade e a história da ciência passam a ser não apenas relevantes, mas essenciais. Tanto as múltiplas facetas de seus signos quanto a dimensão histórico-social do conhecimento científico têm que ser evidenciadas pela prática pedagógica. A historicidade da ciência é defendida por Freire numa entrevista, na qual ele afirma:

"O que a rigorosidade científica precisa saber é, em primeiro lugar, que ela não é uma categoria metafísica, que é uma categoria histórica. O que a rigorosidade precisa saber é que a ciência tem uma historicidade, o conhecimento científico tem uma historicidade. A ciência jamais poderia ser um a priori da história. Ela se gesta, ela é a posteriori.'

A “problematização" a que se propõe Freire passa, necessariamente, por uma valorização do saber próprio do indivíduo que aprende e que, enquanto sujeito, é parte do processo que visa transcender a mera opinião (doxa). Mas Freire vai ainda mais além, estabelecendo no processo de aprendizagem uma relação dialógica, onde dois sujeitos (educador e educando) cognoscentes são mediatizados pelo objeto cognoscível. Como afirma Simões:

"Supera-se assim o recorte idealista no qual o conhecimento tem origem no sujeito $(S \rightarrow O)$, o empirista onde a origem do conhecimento é posta no objeto $(S \leftarrow O)$, como também a visão de um construtivismo do tipo individualista no qual a origem do conhecimento está associada à interação sujeito cognoscente - objeto cognoscível isolados do contexto social $(S \leftrightarrow O)$. A proposição gnosiológica que estaria respaldada na pedagogia freireana seria a de um construtivismo sóciointeracionista, que esquematicamente poderíamos representar assim:

\footnotetext{
${ }^{23}$ Ibid., p. 81.

${ }^{24}$ Apud SIMÕES, A. A. - Op. cit., p. 100.
} 


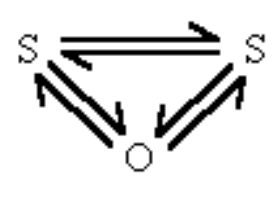

Simões chama nossa atenção para o fato de que a pedagogia dialógica, tal como foi apresentada até aqui, repousa portanto sobre uma gnosiologia do tipo dialética. A relação entre ambas faz aflorar a educação como um processo de permanência e mudança, de continuidade e ruptura, de conservação e transformação. Nas palavras de Freire:

"A educação, porque se realiza no jogo destes contrários que se dialetizam, é "duração".

A educação dura na contradição permanência-mudança.

Esta é a razão pela qual somente no sentido de "duração" é possível dizer que a educação é permanente. Por isto mesmo, permanente, neste caso, não significa a permanência de valores, mas a permanênciado processo educativo, que é o jogo entre a permanência e a mudança culturais.'

Há que se diferenciar a "permanência de valores", que se vincula em parte ao caráter dogmático que o processo educativo pode assumir, da "permanência cultural", inerente a esse mesmo processo e vinculada ao caráter conservador da educação, da forma como o defendemos.

Para Freire, a passagem do conhecimento imediato gerado a partir das experiências cotidianas (ou "senso comum") para o conhecimento sistematizado é um processo complexo, permeado de rupturas.

Reencontramos aqui aspectos da "psicologia do conhecimento científico" de Gaston Bachelard. Como vimos no capítulo precedente, Bachelard propõe que o espírito evolui superando obstáculos, que denomina de "obstáculos epistemológicos". Amplia, em certo sentido, o que dissemos acima, pois as rupturas não se dão apenas entre o "senso comum" e o conhecimento sistematizado, mas apresentam-se como instantes de uma hierarquia filosófica percorrida por cada indivíduo durante o seu processo de aprendizado.

\footnotetext{
${ }^{25}$ SIMÕES, A. A. - Op. cit., p. 103.

${ }^{26}$ FREIRE, P. - Op. cit., p. 84.
} 
Em consonância com uma concepção dialética da construção do conhecimento, o pensamento bachelardiano reconhece a importância da contradição para a ocorrência de rupturas. Ao discutir a superação do conceito animista de massa, afirma esse autor:

"A primeira contradição é então, como sempre, o primeiro conhecimento."

Contudo, Bachelard sabe que o "não" ao conceito anterior nunca é definitivo, donde deriva a noção de "perfil epistemológico". Além disso, alerta-nos acerca das dificuldades de superação dos conceitos, dada a complexidade e articulação do chamado "senso comum" ou "conhecimento imediato":

"Para o cientista, o conhecimento sai da ignorância tal como a luz sai das trevas. O cientista não vê que a ignorância é um tecido de erros positivos, tenazes, solidários. Não vê que as trevas espirituais têm uma sstrutura (...). Mas não é fácil destruir os erros um a um. Eles são coordenados.

Embora refira-se ao "cientista", parece-nos válido e pertinente substituir essa palavra por "professor tradicional" na citação acima.

Mais adiante, afirma Bachelard:

"No que se refere ao conhecimento teórico do real, isto é, no que se refere a um conhecimento que ultrapasse g alcance de uma simples descrição (...), tudo o que é fácil de ensinar é inexato."

Paulo Freire também nos fala dessa questão ao analisar as dificuldades de superação de um pensamento mágico:

"O pensamento mágico não é ilógico nem é pré-lógico. Tem sua estrutura lógica interna e reage, até onde pode, ao ser substituído mecanicistamente por outro.

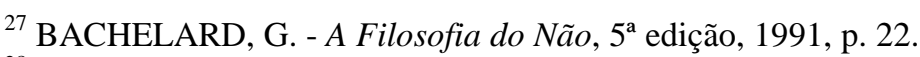

${ }^{28}$ Ibid., p. 11-12.

${ }^{29}$ Ibid., p. 24.
} 
Este modo de pensar, como qualquer outro, está indiscutivelmente ligado a uma linguagem e a uma estrutura como a uma forma de atuar.

Sobrepor a ele outra forma de pensar, que implica noutra linguagem, noutra estrutura e noutra maneira de atuar lhe desperta uma reação natural. Uma reação de defesa ante o "invasor" que ameaça romper seu equilíbrio interno.,

Disso tudo resulta, entre outras coisas, o importante papel do erro, tanto na pedagogia de Paulo Freire quanto na epistemologia de Bachelard. Se esse último, por um lado, sabe que os erros são solidários, e que há obstáculos difíceis de superar, Freire vê no diálogo de sujeitos cognoscentes em torno do objeto cognoscível a possibilidade dessa superação, que não é definitiva, como volta a nos dizer Bachelard.

O erro é algo fundamental, tanto para o desenvolvimento científico quanto para o processo ensino-aprendizagem. Com relação ao primeiro aspecto, a história da ciência ajuda-nos, inclusive, a contestar uma imagem mitificada dos cientistas, revelando seus "erros" no processo de desenvolvimento da ciência. O historiador da ciência Alexandre Koyré, por exemplo, ao discutir o (mesmo) erro cometido por Galileu e Descartes na tentativa de estabelecer a lei de queda dos corpos, afirma:

“(...) para o historiador do pensamento científico, pelo menos para o historiadorfilósofo, o revés, o erro, sobretudo o erro de um Galileu, de um Descartes, são por vezes tão preciosos como os seus êxitos.

Talvez até mais. São, com efeito, muito instrutivos. Permitem-nos-por vezes captar e compreender o andamento secreto do pensamento deles."

Com relação ao papel do erro no processo ensino-aprendizagem, o grande número de estudos acerca dos chamados "conceitos espontâneos" ou "conhecimentos prévios" dos alunos já evidenciou, suficientemente, a necessidade de valorização desse saber na educação científica.

Para Freire, a intervenção do educador deve respeitar o saber do educando, seus "erros", sua cultura, sob pena de transformarmos "educação" em "invasão cultural". Essa última seria uma característica da antidialogicidade:

“Toda invasão sugere, obviamente, um sujeito que invade. (...)

As relações entre invasor e invadidos, que são relações autoritárias, situam seus pólos em posições antagônicas.

\footnotetext{
${ }^{30}$ FREIRE, P. - Op. cit., p. 31.

${ }^{31}$ KOYRÉ, A. - Estudos Galilaicos, 1986, p. 105.
} 
O primeiro atua, os segundos têm a ilusão de que atuam na atuação do primeiro; este diz a palavra; os segundos, proibidos de dizer a sua, escutam a palavra do primeiro. O invasor pensa, na melhor das hipóteses, sobre os segundos, jamais com eles; estes são "pensades" por aqueles. O invasor prescreve; os invadidos são pacientes da prescrição.'

A verdadeira problematização da educação dialógica opõe-se à invasão cultural. No entanto, o ensino tradicional, vinculado como vimos a uma concepção metafísica do conhecimento, assemelha-se mais a uma invasão (antidialógica) do que a uma problematização (dialógica). A escola acaba agindo desse modo ao desprezar muitas vezes o saber dos alunos, e tentar impor-lhes outros "saberes", desvinculados de suas realidades e motivações.

Uma visão mitificada da ciência, apropriada e articulada segundo uma prática pedagógica de raízes metafísicas, só pode resultar em dogmatismo, invasão cultural, antidialogicidade. Deixa de ser educação, para transformar-se em doutrinação. A chamada "educação científica" assume muitas vezes esse caráter, e é também nesse sentido que Feyerabend a critica, por exemplo, ao propor a separação entre ciência e Estado:

"Uma ciência que insiste em ser a detentora do único método correto e dos únicos resultados aceitáveis é ideologia e deve ser separada do Estado e, especialmente, dos processos de educação. Cabe ensiná-la, mas tão-somente àqueles que decidiram aderir a essa particular superstição."

"Um cidadão amadurecido não é um homem que foi instruído em uma especial ideologia - como o puritanismo ou o racionalismo crítico - e que agora é portador dessa ideologia, como de um tumor mental; um cidadão amadurecido é uma pessoa que aprendeu a tomar decisões e que decidiu em favor daquilo que mais lhe convém. (...) Preparando-se para essa escolha, a pessoa estudará as ideologias mais importantes em termos de fenômenos históricos, estudará a ciência como fenômeno histórico e não como o único e sensato meio de enfrentar um problema."

Para nós, entretanto, a ciência tem o seu papel na escola, porquanto tem um papel em nossa cultura. Cabe-nos des-dogmatizar a ciência e a educação científica, problematizando-as.

\section{II.2. A HISTÓRIA DA CIÊNCIA E O ENSINO DE FÍSICA}

\footnotetext{
${ }^{32}$ FREIRE, P. - Op. cit., p. 41-42.

${ }^{33}$ FEYERABEND, P. - Contra o Método, 1977, p. 464-465.
} 
A História da Ciência é mais fascinante que um romance policial. (...)

O estudo da História da Ciência é muito importante, sobretudo para os jovens. Acho que os jovens deveriam ler História da Ciência porque freqüentemente o ensino universitário é extremamente dogmático, não mostrando como ela nasceu. Por exemplo, um estudante pode facilmente imaginar que o conceito de massa seja simples e intuitivo, o que não corresponde à verdade histórica.

Mário Schenberg 34

Emerge da concepção dialética do conhecimento, como pretendemos haver evidenciado, a necessidade pedagógica da história da ciência. Já havíamos apontado, no capítulo anterior, a importância da história da ciência para a formação de pesquisadores e de professores de ciência, dado o seu vínculo epistemológico. A relação concepção de conhecimento $\leftrightarrow$ prática pedagógica, exemplificada acima através da contraposição entre metafísica $\leftrightarrow$ ensino tradicional e dialética $\leftrightarrow$ ensino dialógico, parece-nos reforçar a importância da história da ciência para a formação de professores e pesquisadores em geral. Uma opção por uma concepção dialética do conhecimento torna, como dissemos, a história da ciência essencial para o ensino de ciências, em geral, e para o ensino de física, em particular.

Uma educação científica que apresente a ciência como um fazer humano, portanto contextualizado histórica e socialmente, que evidencie seu caráter inacabado, transitório, bem como as rupturas e transformações pelas quais essa atividade passou através dos séculos não pode, certamente, abdicar da história. Seja no ensino superior, médio ou fundamental, defendemos que aspectos históricos estejam contemplados na prática educativa.

No entanto, de qual história da ciência falamos aqui?

Seguindo o que afirma Zanetic em sua tese de doutoramento, certamente não defendemos aquela história que, quando presente nos textos didáticos tradicionais do ensino médio ou superior, serve apenas como "ilustração":

"Nestes textos, quando estão presentes capítulos, apêndices ou notas históricas, temos quase sempre arremedos de história da ciência: são aquelas seqüencias cronológicas de datas de grandes invenções, de descobertas sensacionais ou de

\footnotetext{
${ }^{34}$ SCHENBERG, M. - Pensando a Física, 1984, p. 30.
} 
nascimento e morte das principais personagens envolvidas nesses acontecimentos, acompanhados de ilustrações que representam essas personagens ou seus feitos.",

Esse tipo de história factual e cronológica, às vezes, mais prejudica do que auxilia uma tentativa de apresentação da ciência tal como a defendida até aqui. Acaba perpetuando muitas vezes concepções ingênuas do fazer científico, estereotipadas e, até, mentirosas.

Zanetic defende a história da ciência tanto na formação dos professores e pesquisadores da área de ciências quanto na formação do cidadão comum contemporâneo que pode (ou não) seguir algum curso superior em outras áreas do conhecimento. Opta por uma história que não seja uma "reconstrução", com o objetivo de selecionar apenas o que pode ser "útil" para a compreensão das teorias e modelos atualmente aceitos:

"A minha argumentação vai no sentido de fazer uma "construção" racional, crítica, polêmica, instigadora do imaginário, (...) que revele além dos sucessos também os fracassos ocorridos ao longo do desenvolvimento da física, enfim, uma história que apresente o caráter dinâmico que foi característica do passado e que, certamente, com uma educação inovadora será ainda mais dinâmica., ${ }^{\text {,3] }}$

Simões, em seu trabalho de dissertação acima citado, faz um excelente levantamento histórico acerca da questão da introdução da história da ciência no ensino de ciências, buscando desde os precursores de tal preocupação ${ }_{38}^{3}$ até trabalhos mais recentes em torno desse tema. Não nos parece fundamental, para nossos propósitos, refazer aqui o seu caminho mas, antes, apontar suas principais conclusões relativamente ao papel da história da ciência numa perspectiva educacional libertadora e dialógica. Simões cita como síntese um trabalho de Michael R. Matthews, que apresenta várias razões que têm sido colocadas em defesa da história da ciência no ensino 39 .

- motivação dos estudantes;

- a humanização dos conteúdos e, como resultado, a permanência dos estudantes na disciplina;

\footnotetext{
${ }^{35}$ ZANETIC, J. - Op. cit., p. 107.

${ }^{36} \mathrm{O}$ autor refere-se aqui à chamada "reconstrução racional", proposta por Imre Lakatos.

${ }^{37}$ Ibid., p. 123.

${ }^{38}$ São apontados os nomes de E. Mach, P. Langevin e P. Duhem, sendo analisadas as idéias dos dois primeiros a esse respeito.
} 
- melhor compreensão dos conceitos científicos através do estudo do seu desenvolvimento e refinamento;

- o valor intrínseco em se conhecer certos episódios da história da ciência;

- a historicização da ciência, ou a demonstração de que a ciência é mutável e que portanto o conhecimento científico atual está sujeito à mudança;

- o rico entendimento do método científico e da natureza da ciência.

A partir do trabalho de Zanetic, acrescentaríamos a essas razões, outras, de caráter mais amplo

- a recuperação da física como área do conhecimento que pode contribuir para a formação cultural geral de um cidadão contemporâneo;

- a história da ciência pode contribuir para a utilização do imaginário, tanto do cientista quanto do cidadão contemporâneo;

- proporcionar uma formação crítica visando uma transformação social, uma desmistificação e humanização da prática científica, e um questionamento da apropriação do conhecimento pelas classes dominantes;

- contribuir para a estruturação dos currículos escolares, particularmente a seleção de temas a serem abordados.

Todas essas razões intercalam-se e complementam-se. Certamente algumas delas são mais importantes do que outras num dado contexto educativo. Não se trata, portanto, de tomarmos a história da ciência de uma forma dogmática, como se ela fosse a solução para todos os problemas do ensino de ciências, em geral, ou de física, em particular.

Segundo Simões, Matthews não deixa, entretanto, de apresentar também as críticas sofridas pelos defensores de uma abordagem histórica da ciência. Resumidamente, estariam essas críticas divididas em duas grandes "frentes" primeira delas divide-se em dois grupos: um deles afirma que a única história possível é uma "pseudo-história", uma história distorcida, imprecisa, com simplificações grosseiras; enquanto o outro grupo diz que a história pode ser "fabricada" para atender a interesses ideológicos ("quasi-history"). A segunda "frente" afirma que a história da

\footnotetext{
${ }^{39}$ Apud SIMÕES, A. A. - Op. cit., p. 198.

${ }^{40}$ ZANETIC, J. - Op. cit., p. 126-127.

${ }^{41}$ Apud SIMÕES, A. A. - Op. cit., p. 198-202.
} 
ciência prejudicaria a formação do cientista, abalando as "certezas" na visão científica dominante, enfraquecendo as concepções dos estudantes.

Matthews combate a primeira "frente" dessa forma, como aponta Simões:

"No que se refere à pseudo-história o autor nos adverte que simplificações de conteúdo ocorrem em qualquer assunto tratado pedagogicamente, seja na Física, na Economia, ou em qualquer outra disciplina. É necessário adequar-se o conteúdo ao nível de desenvolvimento cognitivo dos estudantes. Não haveria razão portanto de ser diferente com a História da Ciência. Já quanto à "quasihistory”, Matthews sustenta que as distorções provocadas o são despropositadamente e que uma melhor formação em História da Ciência ajudaria a corrigir.'

Quanto à segunda “frente", nosso próprio trabalho até aqui permite, acreditamos, tomá-la não como uma crítica, mas como uma defesa da história da ciência. Abalar as “certezas" na ciência significa, antes de tudo, tomá-la de modo não-dogmático, crítico, humano. Isso revela a complexidade do fazer científico. Nesse sentido, a formação do cientista não estaria de forma alguma "prejudicada", mas engrandecida.

Essa crítica certamente surge daqueles que tomariam a análise de Kuhn como uma prescrição, e pensam a melhor maneira de formar um "cientista normal". Como dissemos no início desse capítulo, nossa leitura de Kuhn é outra, e nada impede que uma educação mais humanista e dialógica possa intensificar o progresso científico.

Gostaríamos de finalizar essa seção reafirmando que as diversas razões acima levantadas em favor da utilização da história da ciência no ensino de física inserem-se no contexto da concepção de ciência delineada no capítulo anterior, e das relações dessa com uma concepção dialética do conhecimento. Entretanto, consideramos que a perspectiva histórica seja algo que também deva estar presente na sala de aula, sendo encarada de modo não-dogmático.

A pesquisa em ensino de ciências tem apontado, nos últimos anos, que não há uma metodologia que garanta o "sucesso" educacional. Embora a história da ciência não seja, em si, uma metodologia de ensino, também não pode, ela, garantir tal coisa. Certamente nem todos os estudantes irão motivar-se através de uma educação científica histórica, mas essa perspectiva deve ser-lhes apresentada sob pena de, como dissemos, transformarmos educação em doutrinação.

\footnotetext{
${ }^{42}$ SIMÕES, A. A. - Op. cit., p. 200.
} 


\section{II.3. A INTERDISCIPLINARIDADE}

Além da perspectiva histórica, um outro aspecto que emerge dessa análise e que, acreditamos, pode contribuir para uma educação libertadora e dialógica, é a perspectiva interdisciplinar.

Pretendemos haver evidenciado em que medida a não-historicidade contribui para intensificar o caráter dogmático da educação científica, em geral. Esse dogmatismo, entretanto, acentua e é acentuado por uma prática pedagógica caracterizada pela fragmentação. Resultam os currículos de uma excessiva e artificial compartimentalização do conhecimento: é a perspectiva "disciplinar" que, de início, exclui muitas outras áreas do saber. Zanetic, ao criticar o ensino tradicional de física presente nas escolas públicas, nos diz que:

“(...) há todo um elenco de outras áreas que sequer atingem a sala de aula, não são selecionadas para serem "transmitidas" como formas de conhecimento. Sob outras perspectivas educacionais, outras disciplinas poderiam participar do curriculum, tais como, filosofia (que começa a retornar), psicologia, antropologia, economia, geologia, artes plásticas diversas, política, música clássica e popular, tradições folclóricas, e... história da ciência."

E, mesmo dentro de cada "disciplina", o conteúdo é sub-dividido de modo "estanque", fazendo com que um determinado estudo (a mecânica de Newton, por exemplo) pouca ou nenhuma relação pareça ter com o seguinte (a óptica, por exemplo). A fragmentação é tamanha que, muitas vezes, "cinemática" parece absolutamente não se relacionar com "dinâmica", que se apresenta aos alunos como "outra matéria"!

Certamente que (e é bom deixarmos isso bem claro) a perspectiva disciplinar é importante, no sentido de que o professor de física precisa ser conhecedor da física, para que possa estabelecer claramente os limites de tal conhecimento, seu âmbito de atuação, sua perspectiva do "real". Como afirma Maria Regina D. Kawamura num recente artigo para o jornal Ciência \& Ensino do gepCE da Unicamp, no qual questiona a interdisciplinaridade:

"A idéia de disciplinaridade é importante para demarcar e para poder compor. Somente é possível compor um todo juntando as partes quando você conhece as

\footnotetext{
${ }^{43}$ ZANETIC, J. - Op. cit., p. 18.
} 
partes. A disciplinaridade é o ato de conhecer essas partes. Um todo émuito mais do que a soma das partes, mas é preciso que você tenha essas partes."

Entretanto, o pensar dialético leva-nos a reinterpretar a "soma" das partes. Essa "soma" é algo que se concretiza à custa de uma "perda". Nessa "soma", que é "amplificação", deve-se buscar o estabelecimento dos limites de certo conhecimento. Nesse sentido, um conceito, lei, teoria (ou até disciplina) deixa de possuir um imenso "campo de atuação" que uma abordagem primeira poderia levar a supor. Há uma "perda" que, paradoxalmente, é um "ganho". Desse modo pensamos, por exemplo, a ruptura entre o chamado "senso comum" e o conhecimento sistematizado. A problematização do primeiro o limita, visando sua transcendência.

Contudo: não seria a prática interdisciplinar uma forma de estabelecer esses limites? Um conceito não se esclarece quando compreendemos o que ele não é? Onde ele não se aplica? Segundo Bachelard:

"É no momento em que um conceito muda de sentido que ele tem mais sentido,é então que ele é, em toda verdade, um acontecimento da conceptualização. Mesmo se colocando do simples ponto de vista pedagógico - ponto de vista do qual se desconhece demasiado freqüentemente a importância psicológica - o aluno compreenderá melhor o valor da noção galileana de velocidade se o professor soube expor o papel aristotélico da velocidade no movimento.'

Tomamos essa citação de Bachelard não apenas como uma defesa da história da ciência no ensino, mas como uma defesa da interdisciplinaridade. Acreditamos que o aluno também compreenderá melhor o conceito físico de "tempo" (ou energia, massa, onda, partícula etc) se o professor souber expor as outras acepções que esse conceito adquire em outras áreas do conhecimento, e mesmo na linguagem comum. Essa "riqueza conceitual", muitas vezes, é trazida pelos estudantes para a sala de aula, e ignorada pelo professor.

Não se trata, entretanto, de elegermos simplesmente um "tema" que possa ser abordado, por exemplo, pelos professores das diversas disciplinas que compõem o currículo, se pensamos no ensino médio. Um trabalho dessa natureza pode vir a ser interessante na busca a que nos propusemos aqui, e representa certamente um "primeiro tipo" de pensamento interdisciplinar. Contudo, para nós, a interdisciplinaridade nasce a

\footnotetext{
${ }^{44}$ KAWAMURA, M. R. D. - Disciplinaridade, Sim!, em: Ciência \& Ensino $n^{o} 2$ (jornal do gepCE - FE Unicamp), 1997, p. 5.
} 
partir da problematização, concebida segundo o referencial educacional de Paulo Freire. Para ele, tudo pode ser problematizado e, nesse processo, o educador não é mero espectador, encontrando-se igualmente problematizado:

"É que, na problematização, cada passo no sentido de aprofundar-se na situação problemática, dado por um dos sujeitos, vai abrindo novos caminhos de compreensão do objeto da análise aos demais sujeitos.

O educador, problematizado só em problematizar, "re-ad-mira” o objeto problemático através da "ad-miração" dos educandos. "

A "ad-miração" pode representar, para um dado conceito, a compreensão de suas múltiplas faces. A verdadeira problematização passa, acreditamos, pela interdisciplinaridade. Como problematizar um determinado conteúdo de física, por exemplo, sem efetivamente incorporar os elementos dessa problematização em uma prática subseqüente? E não refletirão esses elementos uma riqueza conceitual e lingüística (cultural, enfim) própria dos estudantes, e que não pode ser desprezada? Não poderão esses elementos contribuir para a "delimitação" do conhecimento em física, numa prática interdisciplinar? Para nós, a resposta às duas últimas questões é a mesma: sim!

Zanetic, em seu trabalho citado anteriormente, aponta-nos a relação entre literatura e física como um dos aspectos importantes para a construção de uma visão da "física como cultura". Textos científicos que são verdadeiras obras literárias podem ser usados tanto na formação de professores quanto nas futuras salas de aula dos mesmos, tendo dois objetivos principais 4 .

- fornecer uma base mínima que favoreça a leitura desse tipo de literatura para o indivíduo, alimentando seu pensamento científico e seu imaginário;

- favorecer a aprendizagem dos aspectos conceituais presentes nas teorias físicas apresentadas na parte mais formal do curso.

Essa é apenas uma das possíveis interfaces do conhecimento em física, pontos de partida de uma abordagem interdisciplinar. Há certamente muitas outras, tais como: física e música, física e psicologia, física e artes plásticas, física e biologia, e assim por diante.

\footnotetext{
${ }^{45}$ BACHELARD, G. - O Novo Espirito Científico, 1985, p. 51.

${ }^{46}$ FREIRE, P. - Op. cit., p. 82.

${ }^{47}$ ZANETIC, J. - Op. cit., p. 162.
} 
O próprio professor de física, no âmbito da problematização a que se propõe, deve explorar as possíveis interfaces do conceito, tema ou assunto que pretenda trabalhar com seus alunos. Tal exploração evidenciará semelhanças e diferenças que podem e devem propiciar atividades novas, que re-criem os significados do objeto cognoscível, pluralizem-no, para a que a compreensão do mesmo dê-se plenamente, de forma re-elaborada, e fruto de uma reflexão profunda. A partir disso podem, os estudantes, "ad-mirar" esse objeto e "re-ad-mirá-lo", uma vez que conhecem os limites do mesmo, no campo do conhecimento sistematizado.

O trabalho a partir de diversos referenciais, dados pelas diversas disciplinas, resulta num aprofundamento, numa objetivação daquele objeto cognoscível (complexo em sua natureza) em torno do qual dois sujeitos, dialogicamente, elaboram suas reflexões. Cada conceito representa, como foi dito, uma teia de relações. E a sala de aula

tear. 


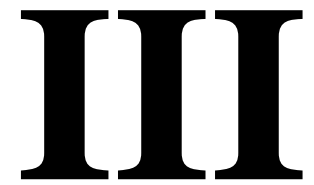

\section{DAS AMPULHETAS E DAS CLEPSIDRAS}

Antes havia os relógios d'água, antes havia os relógios de areia. O Tempo fazia parte da natureza. Agora é uma abstração - unicamente denunciada por um tic-tac mecânico, como o acionar contínuo de um gatilho numa espécie de roleta-russa. Por isso é que os antigos aceitavam mais naturalmente a morte.

Mário Quintana (em "Porta Giratória") 


\section{A HISTÓRIA DA CIÊNCIA E O CONCEITO DE TEMPO : UMA VISÃO PRELIMINAR}

No capítulo precedente procuramos estabelecer uma relação entre concepção de conhecimento científico e prática pedagógica. A opção por uma concepção dialética do conhecimento surgiu concomitantemente a uma crítica ao ensino tradicionalmente ministrado em nossas escolas, e que reflete uma concepção de conhecimento de natureza metafísica, exemplificada através, inclusive, de textos didáticos.

Dentro de tal concepção, esperamos haver evidenciado em que medida a educação pode ser, simultaneamente, conservadora e transformadora, sem por isso ser dogmática e doutrinadora. Apontamos, ao final, duas perspectivas que, acreditamos, devem ser trabalhadas na busca por uma educação libertadora e dialógica, de raiz dialética: a perspectiva histórica e a perspectiva interdisciplinar. Como contemplá-las no ensino de física?

Nessa "encruzilhada" de nosso trabalho, deixaremos de lado a perspectiva interdisciplinar, optando pelo aprofundamento da perspectiva histórica. Não que a primeira seja menos relevante dentro de nossa concepção de educação. Essa atitude reflete apenas um tipo de limitação inerente a esse trabalho.

Com vistas a uma exemplificação de como a perspectiva histórica poderia estar contemplada no ensino de física, tomaremos para nossa análise, a partir de agora, um conceito de fundamental importância na física: o conceito de tempo.

Certamente que o nosso objeto de estudo poderia ser algo mais "amplo", como a "mecânica", ou um pouco mais restrito, como a "dinâmica", ou ainda mais, como a "segunda lei de Newton". Contudo, embora nossa escolha contenha uma aparente simplicidade, o conceito de tempo é extremamente complexo, permeando os diversos ramos do conhecimento físico, dado o seu caráter fundamental. Apesar disso, é um conceito pouco estudado, no que se refere ao ensino de ciências.

Esse capítulo intenciona simplesmente apresentar diversas concepções desse conceito ao longo da história, criando subsídios para uma análise posterior, à luz das discussões realizadas nos capítulos precedentes. Em vista disso, trata-se de "um primeiro contato" com o material histórico, "uma visão preliminar" da história, ainda 
não problematizada pelo discurso epistemológico. Isso será realizado (com relação a um período particular) no capítulo seguinte.

Ainda assim, um estudo detalhado da evolução histórica do conceito de tempo seria, certamente, por demais extenso. Mais modestamente, procuraremos abordar aqui as idéias desenvolvidas por alguns dos principais pensadores que se debruçaram sobre essa questão (específica) ao longo dos séculos. Na medida do possível, tentaremos apontar também alguns aspectos do contexto sócio-cultural no qual eles estavam inseridos.

\section{III.1. O TEMPO NA ANTIGÜIDADE}

Já na pré-história o homem notava mudanças sazonais em seu meio ambiente, tanto no que se refere à abundância de espécies animais e vegetais, como à presença de ciclos regulares na natureza, como o dia e a noite. Não tardou a surgir a percepção de relações entre os ciclos "celestes" e os "biológicos". Foi, no entanto, a fixação do homem à terra que o levou à elaboração dos primeiros calendários, marcas das primitivas civilizações agrícolas. Reciprocamente, o conhecimento das estações foi uma condição para que esse processo ocorresse de modo definitivo.

A história dos calendários, por si só, é algo extremamente fascinante, que mereceria uma abordagem mais extensa. O que nos importa aqui, no entanto, é, em primeiro lugar, a própria idéia de "marcação do tempo" que surge com eles e, em segundo lugar, as possíveis concepções sobre o tempo a eles muitas vezes associadas.

O calendário egípcio, por exemplo, era composto de 12 meses de 30 dias cada, com cinco dias adicionais de festa ao final do ano. Baseado no movimento do sol, dividia-se o ano em três estações: tempo da inundação, tempo da semeadura e tempo da colheita. O ciclo das cheias do Nilo tem profunda relação com a visão de tempo dos egípcios:

"O mito de Osíris, que corporificava esse ciclo de nascimento, morte $e$ renascimento, encerrava uma promessa de imortalidade. Por ocasião da morte do faraó, uma série de ritgs o capacitava a tornar-se Osíris, imune portanto à devastação pelo tempo.'

1 WHITROW, G.J. - O Tempo na História: concepções do tempo da pré-história aos nossos dias, 1993, p.38. 
As pirâmides são verdadeiros monumentos à imortalidade, e o culto a Osíris simbolizava essa busca.

Associado a essa imagem mítica, o tempo, em geral, era concebido como uma seqüência de ciclos recorrentes, fatos que se repetiam ao longo da história. Devemos aos egípcios os primeiros relógios de sol, assim como os primeiros relógios d'água (clepsidras), esses últimos utilizados posteriormente pelos gregos e romanos.

Os babilônios criaram um calendário baseado na lua. Havia doze meses lunares, com 29 ou 30 dias cada, sendo um décimo terceiro mês acrescentado de vez em quando. Devido ao próprio ambiente onde essa civilização desenvolveu-se, assolado por grandes variações climáticas e enchentes, tinham uma visão do mundo marcada por "destruições", o que se reflete em sua mitologia. A visão babilônica do tempo caracteriza-se mais pela inconstância do que pela permanência ou pela idéia de ciclos.

Com relação aos gregos, aponta Boczko:

“Os antigos calendários gregos eram bastante caóticos. Todos eles se baseavam em meses lunares astronômicos, sendo que a intercalação do $13^{\circ}$ mês era feita segundo a vontade da autoridade local. Assim, o calendário diferia de cidade para cidade."

Posteriormente, os gregos procuraram ciclos que pudessem organizar essas intercalações. O mais importante deles foi o Metônico, de 19 anos. Meton observou, por volta de 430 a.C., que 19 anos "solares" correspondiam a 235 lunações, enquanto 19 anos "lunares" correspondiam a 19x12=228 lunações. Era necessário, então, intercalar 235-228=7 meses lunares a cada ciclo de 19 anos.

$\mathrm{Na}$ América, os maias construíram um calendário extremamente preciso e complexo, formado por um "ano solar" de 18 meses de 20 dias - com cinco dias intercalados - perfazendo um total de 365 dias. Havia outros ciclos de importância em sua astronomia, fruto de uma relativamente avançada matemática. Cada dia era um deus, e uma fila de carregadores divinos, numa estrada sem começo nem fim, transportavam cargas representando as divisões do tempo (dias, meses, anos etc).

Como podemos ver, a "marcação do tempo", para as primeiras grandes civilizações, sempre esteve associada aos movimentos dos astros e aos ciclos da

\footnotetext{
${ }^{2}$ Ibid., p. 43-47.

${ }^{3}$ BOCZKO, R. - Conceitos de Astronomia, 1984, p. 16.

${ }^{4}$ WHITROW, G.J. - Op. cit., p. 109-113.
} 
natureza. As observações astronômicas eram uma necessidade, e não apenas fruto de simples curiosidade. Tanto o conhecimento científico como a mitologia e a astrologia retirarão imagens e conceitos dessas observações.

Deixando um pouco de lado a questão dos calendários, encontramos no norte da Pérsia, ainda na antigüidade, a figura de Zaratustra que, presumivelmente tendo vivido na primeira metade do século VI a.C., propôs uma religião unificadora (em lugar do politeísmo dominante) fundada na luta entre o bem e o mal, onde a conduta do homem o levaria a escolher um dos lados. Sua doutrina irá influenciar profundamente o judaísmo, o cristianismo e o islã. ${ }^{\mathrm{E}}$ Modificada após a morte de Zaratustra, ela acabou levando a uma visão do "Tempo" como divindade suprema, criador de todas as coisas. Havia, no entanto duas formas de tempo: o "tempo infinito", indivisível, e o "tempo finito", divisível e associado ao universo:

"Num dado momento, o tempo finito nasceu no tempo infinito. Ele atravessa um ciclo de mudanças até que finalmente retorna a seu estado original, fundindo-se então no tempo infinito. Não há indício de qualquer repetição no ciclo."6

Entre os gregos, particularmente os filósofos pré-socráticos, interessa-nos aqui as idéias de Heráclito de Éfeso (cerca de 540-470 a.C.), para quem todas as coisas surgiram a partir do fogo. Embora isso nos lembre as visões de Tales, Anaximandro e Anaxímenes, no que se refere à busca de um "elemento primordial", segundo Bertrand Russell $^{\text {Z }}$ não podemos vincular seu pensamento à escola de Mileto. Heráclito apresenta concepções realmente novas, e é mais conhecido por nós devido à sua doutrina da "eterna mudança". A contínua transformação das coisas é um processo harmônico, que se dá a partir da luta entre os opostos:

"É o oposto que é bom para nós., ",

"Não compreendem como o divergente fonsigo mesmo concorda; harmonia de tensões contrárias, como de arco e lira."

Seu pensamento teve a sua "máxima" na expressão a seguir:

\footnotetext{
${ }^{5}$ Ibid., p. 48.

${ }^{6}$ Ibid., p. 50.

${ }^{7}$ RUSSELL, B. - História da Filosofia Ocidental, Livro Primeiro, $3^{\mathrm{a}}$ edição, 1969, p. 48.

${ }^{8}$ Apud RUSSELL, B. - Op. cit., p. 52.

9 OS PRÉ-SOCRÁTICOS: fragmentos, doxografia e comentários (coleção “Os Pensadores”), 2 a edição, 1978 , p. 84.
} 
"Nos mesmos rios entramos e não entramos, somos e não somos."

Num mundo em constante mudança, o tempo assume um papel fundamental: o fluir das coisas ocorre no tempo ou, se preferirmos, é antes esse fluir que nos permite abstrair a noção temporal.

As idéias de Heráclito pareceram, a muitos, impossibilitar qualquer conhecimento verdadeiro sobre o mundo. Se tudo muda, o conhecimento é impossível, pois o objeto a ser conhecido transforma-se constantemente. Isso levará outros filósofos, como Parmênides, Platão e Aristóteles, a combater Heráclito, buscando uma "permanência", ao invés da "mudança". O desenvolvimento científico, ao longo de sua história, foi marcado profundamente por esse embate, e podemos considerar que a procura das "leis fundamentais da natureza" sempre foi uma tentativa de descobrir o que permanece na mudança. Encontramos nesse debate, inclusive, as raízes mais profundas das concepções "metafísica" e "dialética" do conhecimento, discutidas no capítulo anterior.

Parmênides (cerca de 530-460 a.C.) considera, como Heráclito, que os sentidos são enganadores. Suas idéias, no entanto, levarão à conclusões diametralmente opostas. Para ele, uma coisa não pode ser e não ser ao mesmo tempo:

"Como pode, então, o que é vir a ser no futuro? Ou como poderia vir a ser? Se vem a ser, então não é; tampouco o é se vai ser no futuro. Assim, o tornar-se desaparece, e o passar não se percebe.

Nega, portanto, a possibilidade de mudança real. Os nossos sentidos revelam apenas o "mundo da aparência", caracterizado pelo tempo e a mudança, enquanto o "mundo da realidade", revelado pela razão, é imutável e atemporal. As palavras, para ele, devem referir-se às coisas que existem. $\mathrm{O}$ nosso pensamento e a nossa linguagem fazem referência a objetos exteriores. Quando nos lembramos de algo, por exemplo, essa lembrança ocorre no agora, não é idêntica ao acontecimento passado. Segundo Whitrow ${ }^{12}$, Parmênides afirmava que somente o presente "é", e o passado e o futuro carecem de significado.

Essa busca pela permanência, pelo que “é”, certamente ecoará em filósofos como Platão e Aristóteles.

\footnotetext{
${ }^{10}$ Apud OS PRÉ-SOCRÁTICOS - Op. cit., p. 84.

${ }^{11}$ Apud RUSSELL, B. - Op. cit., p. 57.

${ }^{12}$ WHITROW, G.J. - Op. cit., p. 56.
} 
Jorge Luis Borges elegeu o "tempo" como um dos cinco temas abordados em suas

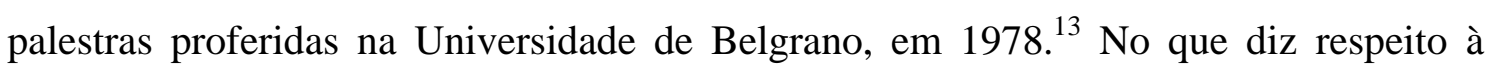
questão acima, Borges afirma que não avançamos muito no problema colocado por Heráclito há séculos: não podemos baixar duas vezes ao mesmo rio não apenas porque o rio é outro, mas também porque nós somos outros ("mudança"). No entanto, nós somos outros mas também somos os mesmos. Nossa memória nos diz isso ("permanência"). Para ele, nunca poderemos resolver o problema de nossa "identidade cambiante". Borges discute ainda os paradoxos de Zenão.

Zenão de Eléia (cerca de 504/1-? a.C.), discípulo de Parmênides, questiona a possibilidade de um espaço e um tempo infinitamente divisíveis. Seu famoso paradoxo (“Aquiles e a tartaruga") refere-se ao espaço, e o fato de Aquiles nunca alcançar a tartaruga nos leva a pensar que: ou o tempo passa diferentemente para Aquiles, ou sua velocidade diminui (infinitamente) à medida que ele se aproxima da tartaruga. Nesse último caso, o espaço seria infinitamente divisível. O paradoxo desapareceria se isso não ocorresse, pois uma seqüência finitamente divisível seria percorrida por "saltos descontínuos", trecho após trecho, resultando num tempo finito. Esse paradoxo, aplicado ao tempo, poderia ser assim explicitado: para que transcorra um minuto, é necessário que transcorra metade de um minuto. Para isso, é preciso que passe metade dessa metade, e assim por diante, infinitamente. Portanto, é impossível que transcorra um minuto, caso o tempo seja infinitamente divisível.

Encontraremos no Timeu, de Platão (427-367), uma apresentação de sua cosmogonia. Nessa obra, o autor procura contrapor aquilo que sempre "é", e por isso pode ser apreendido pela razão e pela inteligência, às coisas que sempre mudam e nunca "são", a respeito das quais podemos ter somente um conhecimento temporário: a “opinião". Platão se pergunta se o universo sempre existiu ou se foi criado, optando por essa última posição. Deus havia criado o universo colocando "ordem" no "caos" (kosmos é a palavra grega para ordem), e utilizou em sua obra os quatro "elementos fundamentais" (água, terra, fogo e ar) - propostos inicialmente por Empédocles.

O interessante para nós, porém, é a discussão que Platão faz acerca do tempo. Segundo ele, o tempo surgiu junto com o Universo. Deus estaria fora do tempo, seria

\footnotetext{
${ }^{13}$ BORGES, J.L. - Borges Oral, $2^{\text {a }}$ edição, 1980, p. 89-107. No prólogo desse livro, o autor afirma que o tempo "sigue siendo para mí el problema esencial de la metafísica."
} 
"eterno", não tendo passado, presente nem futuro. Isso porque, como aponta Roberto de Andrade Martins 14 , Deus é perfeito e, portanto, não pode mudar. Sua mudança o faria ficar "melhor" ou "pior". No primeiro caso, ele ainda não seria perfeito, e no segundo ele deixaria de sê-lo. É interessante a maneira como Platão associa, à idéia de mudança, temporalidade.

A origem do tempo é assim representada:

"Quando o pai percebeu vivo e em movimento o mundo que ele havia gerado à semelhança dos deuses eternos, regozijou-se, e na sua alegria determinou deixálo ainda mais parecido com seu modelo. E por ser esse modelo um animal eterno, cuidou de fazer também eterno o universo, na medida do possível. Mas a natureza eterna desse ser vivo não podia ser atribuída em toda sua plenitude ao que é engendrado. Então, pensou em compor uma imagem móbil da eternidade, e, no mesmo tempo em que organizou o céu, fez da eternidade que perdura na unidade essa imagem eterpg que se movimenta de acordo com o número e a que chamamos tempo.'

Segundo Whitrow:

"A estreita associação que estabeleceu entre o tempo e o universo conduziu Platão a considerar o tempo como efetivamente produzido pelas revoluções da esfera celeste. Um legado permanente de sua teoria do tempo é a idéia de que este e o universo são inseparáveis."

Já Aristóteles (384-322) discorda (em parte) de Platão, uma vez que não cogita uma "criação" do tempo, que para ele não pode cessar. Russel 17 aponta que os seguidores cristãos de Aristóteles foram obrigados a rejeitar esse aspecto de seu pensamento, uma vez que a Bíblia admite um princípio de tudo. Associa o tempo ao movimento, mas admite que esse último pode cessar. No entanto, o movimento dos céus não pode, fornecendo por isso uma medida perfeita do tempo. Em sua Física, Aristóteles fala também que o tempo supõe uma numeração, sendo o "número" do movimento com relação ao "antes" e "depois":

\footnotetext{
${ }^{14}$ MARTINS, R. A. - O Universo: teorias sobre sua origem e evolução, $2^{\mathrm{a}}$ edição, 1994, p. 58.

${ }^{15}$ PLATÃO - Diálogos (Vol.XI - Timeu), 1977, p. 53.

${ }^{16}$ WHITROW, G.J. - Op. cit., p. 57.

${ }^{17}$ RUSSELL, B. - Op. cit., p. 240.
} 
"Não apenas medimos o movimento pelo tempo, mas também o tempo pelo movimento, porque eles se definem um ao outro. O tempo marca o movimento, visto que é seu número, e o movimento marca o tempo." 18

Há mais detalhes e sutilezas na concepção aristotélica do tempo, dos quais trataremos no capítulo seguinte, onde aprofundaremos também outros aspectos de sua cosmologia.

Alguns pensadores gregos (os estóicos) adotaram uma visão de "tempo cíclico", no sentido de repetição de acontecimentos passados. Essa forma de conceber o tempo contrasta com a dos judeus, uma vez que para esses haveria uma linearidade, da criação até o triunfo do povo eleito (Israel). ${ }^{19}$ No entanto, isso também pode ser entendido como um "retorno" à uma condição perdida no passado. A idéia de tempo linear foi incorporada ao cristianismo e, conseqüentemente, marcou profundamente a visão ocidental sobre o tempo. Nas palavras de Whitrow:

“Uma vez que consideravam a crucifixão um evento não passível de repetição, o tempo devia ser linear, e não cíclico. Esta visão essencialmente histórica do tempo, com sua ênfase pqrticular na não-repetibilidade dos eventos, é a própria essência do cristianismo.'

O poeta Lucrécio (98-55 a.C.), defensor das idéias atomistas de Epicuro, Leucipo e Demócrito, tinha idéias realmente avançadas para a época, uma vez que defendia um universo infinito em todas as direções, não importando em que região desse universo nos coloquemos. 2 Também é profundo em sua concepção sobre o tempo, embora essa questão fique por tratar, em sua obra:

“(...) o tempo não existe por si: é dos próprios acontecimentos que vem o sentimento do que se deu no passado, depois do que é presente, em seguida do que há de vir; na realidade, ninguém tem idéia do tempo em si próprio, separado do movimento das coisas e do seu plácido repouso.'

\footnotetext{
${ }^{18}$ Apud WHITROW, G.J. - Op. cit., p. 57.

${ }^{19}$ WHITROW, G.J. - Op. cit., p. 66-72.

${ }^{20}$ Ibid., p. 72-73.

${ }^{21}$ MARTINS, R. A. - Op. cit., p. 45.

${ }^{22}$ LUCRÉCIO - Da Natureza (coleção “Os Pensadores”), 2ª edição, 1980, p. 37.
} 


\section{III.2. O TEMPO NO FIM DA ANTIGÜIDADE E NA IDADE MÉDIA}

Plotino (204-270), considerado o último dos grandes filósofos da antigüidade e um dos fundadores do neoplatonismo, manifestou também sua visão pessoal sobre o tempo. Para ele, há três tempos: o presente atual, que na verdade já pertence ao passado, o presente do passado, que se chama memória, e o presente do futuro, apenas imaginado por nossa esperança ou nosso medo. ${ }^{23}$ Plotino, que não era cristão, acreditava numa "alma do mundo" capaz de medir o tempo. Embora considerasse o cristianismo como forma inferior de sabedoria, seu pensamento influenciou Santo Agostinho e outros teólogos cristãos posteriores.

Um personagem realmente importante para nós, dada a profundidade de suas reflexões sobre o tempo, foi Santo Agostinho (354-430). Nascido cerca de quarenta anos após o cristianismo tornar-se a religião oficial do Império Romano do Ocidente, Agostinho só o abraçará em 386, quando descobre o neoplatonismo. ${ }^{24}$ Em suas Confissões, escritas pouco mais de dez anos depois, procura compreender o significado da frase do Gênesis: "no princípio Deus criou o céu e a Terra". Como nada material poderia existir antes da criação, Agostinho conclui que o criador fez o mundo a partir da palavra. Mas não é soante e transitório o Verbo divino,

“(...) o qual é pronunciado por toda a eternidade e no qual tudo é pronunciado eternamente. Nunca se acaba o que estava sendo pronunciado nem se diz outra coisa para dar lugar a que tudo se possa dizer, mas tudo se diz simultânea $e$ eternamente. Se assim não fosse já hqueria tempo e mudança, e não verdadeira eternidade e verdadeira imortalidade."

Em seguida procura responder à questão: o que estaria Deus fazendo antes da criação? Sua resposta: "não sei". E é nesse ponto que começam suas conjecturas sobre o tempo, numa tentativa de apresentar alguma solução à questão colocada anteriormente:

"Sendo, pois, Vós o obreiro de todos os tempos - se é que existiu algum tempo antes da criação do céu e da terra -, por que razão se diz que Vos abstínheis de toda a obra? Efetivamente fostes Vós que criastes esse mesmo tempo, nem ele podia decorrer antes de o criardes! Porém, se antes da criação do céu e da terra

\footnotetext{
${ }^{23}$ BORGES, J. L. - Op. cit., p. 95

${ }^{24}$ Acerca da relação de Santo Agostinho com o pensamento de Platão ver: KOYRÉ, A. - Aristotelismo e Platonismo na Filosofia da Idade Média. In: KOYRÉ, A. - Estudos de História do Pensamento Científico, 1991, principalmente p. 30-34.

${ }^{25}$ AGOSTINHO, STO. - Confissões (coleção “Os Pensadores”), 2ª edição, 1980, p. 213-214.
} 
não havia tempo, para que perguntar o que fazíeis, então? Não podia haver "então" onde não havia tempo. Não é no tempo que Vós precedeis o tempo, pois, doutro modo, não seríeis anterior a todos os tempos.

Agostinho passa, dessa forma, a tentar responder "o que é o tempo?". Para ele, o "passado" já não existe, e o "futuro" ainda não veio. Numa tentativa de atribuir realidade ao "presente", passa a considerar alguns intervalos de tempo (cem anos, um ano, um dia), mostrando que sempre há, em qualquer divisão que se faça, um passado que já não é, e um futuro que ainda será. Conclui que o presente não tem nenhuma "duração":

"Se pudermos conceber um espaço de tempo que não seja suscetível de ser subdividido em mais partes, por mais pequeninas que sejam, só a esse podemos chamar tempo presente. Mas este voa tão rapidamente do futuro ao passado, que não tem nenhuma duração. Se a tivesse, diwidir-se-ia em passado e futuro. Logo, o tempo presente não tem nenhum espaço."

Numa passagem que nos lembra Parmênides, afirma Agostinho que as lembranças passadas deixaram vestígios em nosso espírito, e a memória evoca essas visões no presente. Da mesma forma, as visões futuras são prognósticos de coisas presentes que já existem, não existindo de fato. De modo semelhante a Plotino, nos propõe então adotar uma nova terminologia, com três "tempos": presente das coisa passadas, presente das presentes, e presente das futuras. Apesar de ter afirmado que o presente não tem duração, Agostinho admite que podemos comparar intervalos de tempo, na poesia ou na música, e dizer, por exemplo, que "uma sílaba tem o dobro de tempo de outra".

Em conseqüência disso irá negar que o tempo seja o movimento dos corpos, em geral, e dos astros, em particular. Se os astros deixassem de se mover, ainda assim poderíamos avaliar se o movimento de uma roda é mais rápido ou mais lento a cada volta. Também as sílabas por nós pronunciadas continuariam sendo "longas" e "breves". Além disso, podemos comparar o tempo que um objeto ficou parado com o tempo que permaneceu em movimento.

Não é possível que o movimento do sol constitua o dia:

"Ninguém me diga, portanto, que o tempo é o movimento dos corpos celestes. Quando, com a oração de Josué, o Sol parou, a fim de ele concluir vitoriosamente

\footnotetext{
${ }^{26}$ Ibid., p. 217.

${ }^{27}$ Ibid., p. 219.
} 
o combate, o Sol estava parado, mas o tempo caminhava. Este espaço de tempo foi o suficiente para executar e para pôr termo ao combate.'

Nesse ponto, Agostinho desespera-se diante do problema, dizendo que ignora o que seja o tempo, embora saiba que diz todas essas coisas no tempo.

"E como posso saber isto, se ignoro o que seja o tempo? Acontecerá talvez que não saiba exprimir o que sei? Ai de mim, que nem ao menos sei o que ignoro!'20

Acaba por afirmar que o tempo é "distensão", mas não sabe de quê. Por fim, Agostinho diz que, quando mede os tempos, o faz por via de seu espírito. As expectativas futuras passam pelo espírito em direção à memória, deixando uma impressão que permanece. A medida dessa impressão, no presente, é o que é medido quando se mede os tempos:

“Em ti, ó meu espírito, meço os tempos! (...)

Aquilo que o espírito espera passa através do domínio da atenção para o domínio da memória.'

Há, de certo modo, uma linha de raciocínio que, no particular aspecto da noção de tempo, une Parmênides a Santo Agostinho, passando por Platão e Plotino. E, nesse ínterim, é interessante notar como a visão aristotélica, que associava o tempo ao movimento, apesar de negada por Agostinho, foi transformada pelo pensamento cristão posterior, que incorporou boa parte da obra de Aristóteles.

Em particular, São Tomás de Aquino (1225-1274) discute a existência de três tipos de tempo: o dos corpos e fenômenos terrestres (uma sucessão com começo e fim definidos), a eternidade "atemporal” (prerrogativa de Deus apenas), e o tempo dos anjos, dos corpos celestes e das idéias (com início, mas sem fim).

Em seu Compêndio de Teologia, São Tomás, após afirmar a existência, imobilidade e eternidade de Deus, deixa claro a relação que vê entre tempo e movimento:

"De quanto expusemos até aqui evidencia-se que não há em Deus qualquer sucessão temporal, senão que Deus existe totalmente e simultaneamente. A sucessão temporal ocorre exclusivamente nas coisas que de um modo ou de outro

\footnotetext{
${ }^{28}$ Ibid., p. 224.

${ }^{29}$ Ibid., p. 225.

${ }^{30}$ Ibid., p. 228.

${ }^{31}$ WHITROW, G.J. - Op. cit., p. 148.
} 
estão sujeitas ao movimento, de vez que são o antes e o depois no movimento que constituem a sucessão temporal. Ora, Deus não está em absoluto sujeito ag movimento (...). Donde se infere que não há n'Ele qualquer sucessão de tempo.'32

A visão aristotélica do tempo reaparece aqui em São Tomás, fundida agora com suas teses religiosas.

Mais adiante, afirma ele a unidade e simplicidade de Deus, que opera não por necessidade, mas por sua livre vontade. Segundo São Tomás, isso não caracterizaria qualquer mudança em Deus, embora admita ele que, diante dessa "livre vontade" divina, uma questão poderia ser colocada: por que razão Deus criou o mundo num dado momento e não em outro? Não implicaria isso num Deus mutável?

São Tomás acaba por defender que o próprio tempo, bem como as coisas nele criadas, tiveram o seu início quando Deus assim o determinou:

"Conseqüentemente, no que tange à criação universal das coisas, entre as quais figura também o tempo, o que interessa não é o porquê do agora e do antes, mas por que razão Deus quis que houvesse uma medida de tempo. Ora, isto depende da vontade divina, para a qual é irrelevante assinalar este ou aquele período de tempo."

Como vemos, a visão de São Tomás tem laços com o pensamento de Platão (criação do tempo junto com o universo) e com algumas indagações de Santo Agostinho (o porquê da criação do mundo num dado instante e não em outro), embora baseie-se fundamentalmente em Aristóteles.

$\mathrm{Na}$ transição para a idade média, muito do conhecimento grego se perdeu. Boa parte dele, no entanto, foi traduzida para o árabe, retornando à Europa séculos mais tarde, quando da invasão da península ibérica. O "mundo islâmico" constituiu-se em um pólo de conhecimento durante esse período. A "marcação do tempo" passou a ser algo extremamente importante para os muçulmanos, que necessitavam determinar com precisão as horas corretas de oração, bem como a direção correta de Meca. Construíram para isso grandes relógios d'água, assim como astrolábios. 34

Desenvolveram uma teoria do tempo descontínuo, que teve sua maior expressão com Moisés Maimônides, pensador judeu do século XII, que escreveu em árabe. Diz ele:

\footnotetext{
${ }^{32}$ TOMÁS DE AQUINO, STO. - Compêndio de Teologia (coleção “Os Pensadores”), 1973, p. 79.

${ }^{33}$ Ibid., p. 103.
} 
"O tempo é composto de átomos de tempo, isto é, de muitas partes, que, em razão de sua curta duração, não podem ser divididas (...) Uma hora é, por exemplo, dividida em 60 minutos, o segundo em 60 partes e assim por diante; ao cabo de dez ou mais sucessivas divisões por 60, obtém-se elementos de tempo que não são passíveis de divisão, e são de fato indivisíveis."

Como isso nos faz lembrar as idéias dos atomistas gregos! No entanto, aponta Whitrow, é difícil encontrar raízes desse pensamento de "tempo atomístico" entre os gregos. Poderia, quem sabe, haver alguma ligação com o pensamento indiano, uma vez que os sautrânkitas (uma seita budista surgida por volta de II a.C.) diziam que as coisas existiam somente por um instante, sendo substituídas em seguida por cópias de si mesmas.

O problema da "marcação do tempo" afetava também os chineses, que desenvolveram relógios d'água bastante sofisticados, além do uso de velas graduadas e bastões de incenso:

"Em alguns desses relógios, diferentes porções de incenso exalavam diferentes aromas, pelosquais as pessoas de olfato apurado podiam identificar a hora aproximada.'

Os primeiros relógios mecânicos parecem ter surgido na Europa, no final do século XIII. Herdeiros de mecanismos destinados a reproduzir os movimentos dos astros (espécies de "calendários mecânicos"), utilizavam pesos suspensos e rodas dentadas, num mecanismo conhecido como "haste e folha". O desenvolvimento desses objetos encontra-se ligado à Igreja, que concentrou o saber durante a Idade Média. Os serviços religiosos (orações etc), assim como o badalar dos sinos, exigiam pontualidade. Como aponta Whitrow:

"A palavra inglesa clock é etimologicamente relacionada com a palavra latina medieval clocca e com a palavra francesa cloche, que significam sino. Os sinos tinham papel de destaque na vida medieval, e mecanismos para tocá-los, feitos de rodas dentadas e alavancas que oscilavam, podem ter contribuído para a invenção de relógios mecânicos.",

\footnotetext{
${ }^{34}$ WHITROW, G.J. - Op. cit., p. 94-95.

${ }^{35}$ Apud WHITROW, G.J. - Op. cit., p. 96.

${ }^{36}$ WHITROW, G.J. - Op. cit., p. 108.

${ }^{37}$ Ibid., p. 120.
} 
Inicialmente destinados às grandes catedrais, aos poucos surgiram relógios públicos e, no século XV, os primeiros relógios de algibeira. As ampulhetas, ou relógios de areia, surgiram mais ou menos na mesma época (século XIV), sendo uma alternativa aos relógios d'água, que congelavam no inverno. Nelas, utilizava-se pó de casca de ovo, uma vez que a areia comum alargava o orifício por onde escoava.

O importante para nós, nesse momento, é assinalar como esse desenvolvimento influenciou fortemente a vida diária e a visão comum sobre o tempo. Cada vez mais o tempo passa a ser "medido", "racionalizado" e "economizado". Horários fixos passam a ser estabelecidos para uma série de atividades, principalmente no que se refere ao estudo e ao trabalho. ${ }^{38}$ Encontramos certamente nessa época, de profundas transformações políticas, sociais e econômicas, as raízes de muitos aspectos da maneira como o tempo é vivenciado por um cidadão comum de nossa sociedade contemporânea.

\section{III.3. O TEMPO E O NASCIMENTO DA CIÊNCIA MODERNA}

No século XVI - mais precisamente em 1582 - ocorre uma alteração no calendário juliano 39 (solar), que fora introduzido em 45 a.C. em substituição ao antigo calendário lunar do Império Romano (foi somente em 525 d.C. que adotou-se a contagem dos anos segundo uma "era cristã", a partir de cálculos feitos por Dionísio, um monge que vivia em Roma). Essa alteração deveu-se a uma defasagem acumulada de cerca de dez dias entre o início "real" da primavera e o seu início segundo o calendário juliano (o ano juliano durava 365,25 dias, enquanto o ano solar verdadeiro dura 365,2422 dias, aproximadamente), resultando na necessidade de reformulação do método de cálculo da data da Páscoa. Embora o calendário gregoriano seja o adotado por nós, hoje em dia, sua aceitação não foi imediata, havendo países que o adotaram somente nesse século, como a Turquia, que o fez em 1927.

Para a filosofia e a ciência, no entanto, estava por vir uma alteração mais profunda. Galileu Galilei (1564-1642) irá desferir duros golpes contra o aristotelismo ainda dominante na descrição do universo, em geral, e dos demais movimentos, em

\footnotetext{
${ }^{38}$ Ibid., p. 126-132.

39 BOCZKO, R. - Op. cit., p. 17-24. Ver também TARSIA, R. D. - O calendário Gregoriano. Revista Brasileira de Ensino de Física, 1995, 17 (1), p. 50-54.
} 
particular. Ao defender a mobilidade da Terra, inaugura uma nova "interpretação natural" $"$, baseada na relatividade do movimento.

Galileu "matematiza a experiência" ao estabelecer sua lei de queda dos corpos. E é nesse ponto em particular que o seu trabalho nos diz respeito aqui, uma vez que a mudança de velocidade dos corpos em queda dá-se a uma taxa constante relativamente

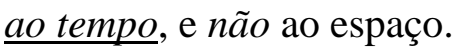

Nos Discorsi, publicado em 1638, Galileu apresenta a lei de queda dos corpos e a sua definição de "movimento naturalmente acelerado". Como veremos no capítulo posterior, tal definição significa acréscimos iguais de velocidade ocorrendo em iguais intervalos de tempo, o que não é (de modo algum) a única definição possível. Surge também, em sua análise, o problema dos infinitésimos, que o faz explicitar sua visão de um tempo contínuo, com infinitos instantes.

A visão manifesta por Galileu, após haver "temporalizado" o movimento de queda dos corpos, é um prelúdio da síntese newtoniana, tanto no que se refere ao conceito de tempo, propriamente dito, quanto ao desenvolvimento do cálculo diferencial e integral.

Galileu também desenvolveu estudos sobre pêndulos, e parece ter imaginado aplicá-los aos relógios mecânicos. No entanto, será Christian Huygens (1629-1695) o primeiro a desenvolver um relógio de pêndulo. No século XVIII, o problema da determinação da longitude no mar levou ao aprimoramento dos relógios, tornando-os mais precisos e capazes de suportar perturbações durante a navegação.

Ainda no século XVII, René Descartes (1596-1650) propõe uma teoria bastante complexa para explicar o universo. Admite a presença de Deus para o seu surgimento, sendo sua ação responsável por "quebrar" a matéria primordial e colocá-la em movimento. As "leis naturais", criadas por Deus, acarretariam o desenvolvimento posterior do mundo. A cosmologia de Descartes, essencialmente qualitativa, será alvo de duras críticas por parte de Newton.

Uma discussão detalhada sobre a cosmologia de Descartes foge aos propósitos dessa apresentação. Interessa-nos aqui somente apontar dois de seus aspectos: primeiramente, o fato dele buscar "leis naturais" que sejam capazes de explicar o

\footnotetext{
${ }^{40}$ Essa expressão, como vimos no capítulo I, é utilizada por Feyerabend em sua discussão sobre a obra de Galileu, particularmente no que se refere à argumentação deste em favor da doutrina de Copérnico. FEYERABEND, P. - Contra o Método, 1977, principalmente capítulos VI e VII.

${ }^{41}$ MARTINS, R. A. - Op. cit., p. 81-89.
} 
desenvolvimento do universo (bem como suas características atuais) a partir do seu (possível) início. Essa tentativa, que é a base da cosmologia moderna, tem suas raízes entre os gregos, mas será realizada por um número cada vez maior de pensadores a partir de Descartes (os mais importantes, imediatamente após, talvez sejam Laplace e Kant, no século XVIII). E essas "cosmologias" nos dirão respeito na medida em que apontem para um universo com um "início" no tempo ou não. E é justamente esse o segundo aspecto interessante em Descartes: ele admite um início temporal.

Isaac Barrow, antecessor de Newton na cátedra de matemática em Cambridge, expõe sua visão sobre o tempo em um trabalho de 1670:

"O tempo não implica movimento, na medida em que é absoluto e no que diz respeito à sua natureza intrínseca; como tampouco indica repouso; quer as coisas se movam ou estejam paradas, quer durmamos ou estejamos despertos, o Tempo segue a natureza uniforme de seu curso."

"o Tempo tem apenas comprimento, é similar em todas as suas partes e pode ser visto como constituído por umg simples adição de instantes sucessivos ou um fluxo contínuo de um instante.

A analogia com uma "linha geométrica" é evidente, e o caráter absoluto que Barrow confere ao tempo nos faz achar que a citação acima poderia certamente ter sido extraída dos Principia. De fato, em sua principal obra, como veremos no capítulo subseqüente, Newton procura separar o que chama de "tempo absoluto" do "tempo relativo". O primeiro é o "tempo da mecânica", enquanto o segundo é uma espécie de "sombra" do primeiro, resultado de medidas e vinculado à nossa percepção.

Isaac Newton (1642-1727) "absolutizou" não apenas o tempo, trazendo-o definitivamente para o formalismo da mecânica, mas também o espaço. No Opticks (Livro III - Parte 1 - Q31), ele caracteriza o espaço absoluto como sendo o "sensório de Deus". Quanto ao tempo, Deus também faz-se presente. Isso aparece em sua concepção do $d t$, ou infinitésimo de tempo, que representava a ação de Deus a cada instante, como um "regulador" de tudo o que ocorre no universo:

"Tanto a força da gravidade como a força entre as partículas da matéria eram compreendidas como fazendo parte de um ser espiritual. Esse ser era Cristo que agia como representante de Deus, assegurando a contínua relação de Deus com a criação, transformando a vontade de Deus em ação no mundo. Portanto o Deus

\footnotetext{
${ }^{42}$ Apud WHITROW, G.J. - Op. cit., p. 146-147.
} 
Newtoniano não corre o risco de tornar um ausente senhor da Terra (como o Deus Cartesiano), pois tem Cristo sempre agindo por ele no mundo.

Essa visão da atuação divina, que será criticada por Leibniz, procurava ir de encontro ao mecanismo de Descartes, por considerar que esse possibilitaria o "ateísmo".

Somente nesse século, com a recuperação e o estudo de manuscritos desconhecidos de Newton, tornaram-se mais claras algumas de suas idéias, bem como as influências exercidas sobre o seu pensamento. Rodrigues estabelece profundas relações entre vários conceitos da obra de Newton e o pensamento dos estóicos, dos neoplatônicos, da filosofia hermética e da alquimia, entre outras influências. Torna-se claro como Newton buscou, nessas fontes, ajuda para resolver problemas colocados para ele em suas reflexões filosóficas.

No entanto, a sua preocupação com o ateísmo acaba levando à construção de uma mecânica que, em sua formulação matemática, possibilita eliminar a presença de Deus:

"Ensaiamos chamar de paradoxal a situação conflitante que se apresenta entre os conceitos de Newton, que pretendem conter seus princípios metafísicos, e a formulação matemática das leis dentro das quais os conceitos se manifestam.

As visões "deterministas" e "mecanicistas" da obra de Newton devem-se, portanto, mais aos "newtonianos" do que ao próprio Newton. Apontaremos a seguir alguns aspectos decorrentes (matematicamente) de sua mecânica, no que se refere ao conceito de tempo.

Um primeiro aspecto interessante da mecânica newtoniana é o fato dela ser "reversível", ou seja, invariante segundo uma transformação temporal que troque $t$ por t. Dito de outro modo, os sistemas ditos "conservativos" (nos quais a energia mecânica total permanece constante) não são capazes de propiciar um sentido preferencial para o transcorrer do tempo. Assim, se filmássemos um pêndulo conservativo que oscila, não seríamos capazes de decidir, ao assistirmos a uma exibição posterior, se o filme estaria sendo projetado "para frente" ou "para trás". As duas situações nos pareceriam familiares, obedecendo às mesmas leis da mecânica.

Por outro lado, nos sistemas ditos "dissipativos" (onde a energia mecânica total não permanece constante), somos capazes de distinguir o sentido de projeção do filme.

\footnotetext{
${ }^{43}$ RODRIGUES, I.G. - Aspectos Epistemológicos da Mecânica de Newton - Novas Formas de Compreensão dos Conceitos (Dissertação de Mestrado), IFUSP, 1988, p. 115.

${ }^{44}$ Ibid., p. 95.
} 
Entretanto, se eles também devem, em princípio, obedecer às mesmas leis da mecânica, como explicar uma "irreversibilidade macroscópica" de inúmeros sistemas (representada por exemplo por um aumento da entropia) se, "microscopicamente", as leis que os regem são "reversíveis" temporalmente? Esse é o cerne do argumento de J. Loschmidt contra Boltzmann, apresentado no âmbito da teoria cinética em 1877. Somente com o advento da mecânica estatística será encontrada uma solução (abordada mais adiante) para esse "paradoxo da reversibilidade", que implicará numa "quebra de simetria temporal", uma vez que o "fluir do tempo" passará a ter um sentido preferencial: do passado para o futuro.

Além disso, o tempo, sendo absoluto, independe do referencial. Isso significa que dois referenciais inerciais que se desloquem, um em relação ao outro, perceberão o transcorrer do tempo da mesma maneira. As transformações de Galileu expressam claramente essa idéia, que será negada pela teoria da relatividade:

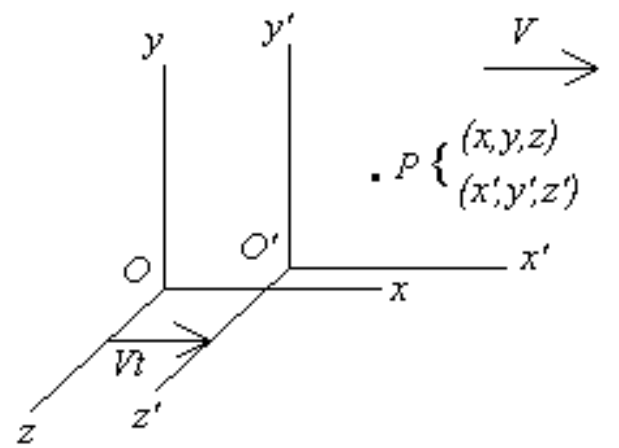

$$
\begin{gathered}
x=x^{\prime}+v t \\
y=y^{\prime} \\
z=z^{\prime} \\
t=t^{\prime} \\
V: \text { velocidade (cte) de } O^{\prime} \text { em } \\
\text { relação a } O, \text { paralela aos } \\
\text { eixos } x \text { e } x !
\end{gathered}
$$

Outra decorrência da formulação de Newton das leis da mecânica é a idéia de "ação instantânea à distância", ou seja, uma transmissão de informação a uma velocidade infinita. Imaginando-se, por exemplo, dois corpos materiais separados por uma certa distância, o par ação-reação referente à interação gravitacional entre ambos encontrar-se-á na reta que une os respectivos centros de massa dos corpos. Ao deslocarmos um deles de sua posição original, deslocamos simultaneamente essa reta e, conseqüentemente, o par ação-reação. Isso representa uma transmissão instantânea de informação (a simultaneidade é, nesse caso, uma noção absoluta).

\footnotetext{
45 Acerca da reversibilidade do tempo na mecânica clássica ver: SACHS, R. G. - The Physics of Time Reversal, 1987, principalmente capítulo 2.

${ }^{46}$ Como vimos acima, a visão newtoniana de tempo absoluto é muito mais rica do que a encontrada nos livros didáticos, embora em alguns deles ela esteja, de certo modo, subjacente.
} 
As idéias de Newton sobre tempo e espaço sofreram críticas por parte de pensadores da sua época e posteriores. Dentre eles, destacamos aqui um contemporâneo de Newton: Gottfried W. Leibniz (1646-1716).

Para Leibniz, o tempo não tem uma existência independente das pessoas que o concebem. Ao contrário, é a "ordem sucessiva das coisas" que nos dá a noção de tempo, sendo ele, pois, relativo. Diante da questão de por que Deus não havia criado o mundo algum tempo antes do momento em que o fez (lembremos de Santo Agostinho!), usa Leibniz o seu "princípio da razão suficiente", segundo o qual nada pode existir sem uma causa que o faça existir daquele modo. Se o tempo fosse algo "fora das coisas temporais" (absoluto, portanto), seria difícil, com base nesse princípio, explicar por que Deus optou por um instante e não por outro. Segundo ele, em trechos de suas cartas com Clarke (discípulo de Newton):

"15. É uma ficção semelhante, i.e., impossível supor que Deus tenha criado o mundo alguns milhões de anos antes. Os que se perdem em semelhantes ficções não saberiam responder aos que argumentassem em favor da eternidade do mundo. Com efeito, não fazendo Deus nada sem razão e não se podendo apontar nenhuma porque não criou o mundo antes, concluir-se-á que, ou ele não criou nada absolutamente, ou produziu o mundo antes de qualquer tempo assinalável, a saber, o mundo é eterno. Mas quando se mostra que o começo, qualquer que seja, é sempre a mesma coisa, cessa a questão de saber por que não foi de outro modo. 16. Se o espaço e o tempo fossem absolutos, isto é, se não fossem senão certa ordem das coisas, o que afirmo seria contraditório. Não sendo, porém, assim, a hipótese é contraditória, ou seja, é uma ficção impossível.'

Para Leibniz, o tempo é algo "ideal", constituindo-se a partir de relações, o que não o impede de ser dotado de "quantidade":

"Assim, como já deixei dito, supor que Deus tenha criado o mesmo mundo mais cedo é supor algo de quimérico. É fazer do tempo uma coisa absoluta, independente de Deus, a passo que o tempo deve coexistir com criaturas, e não se concebe senão pela ordem e quantidade de suas mudanças.'

Alexandre Koyré nos chama a atenção para o fato de que o Deus de Leibniz não é o Deus de Newton, e isso está na base da divergência entre ambos. ${ }^{49}$ Mais uma citação

\footnotetext{
${ }^{47}$ LEIBNIZ, G.W. - Correspondência com Clarke (coleção "Os Pensadores"), $2^{\mathrm{a}}$ edição, 1983, p. 183184.

${ }^{48}$ Ibid., p. 205.

${ }^{49}$ KOYRÉ, A. - Do Mundo Fechado ao Universo Infinito, s/d, p. 232-233.
} 
de Leibniz (com a qual certamente Newton não concordaria) evidencia-nos isso, e nos remete ao que foi dito anteriormente sobre a visão newtoniana do papel de Deus:

"Newton e seus asseclas têm ainda uma divertidíssima opinião sobre a obra de Deus. Conforme eles, Deus de vez em quando precisa dar corda em seu relógio, porque senão ele deixaria de andar. O cientista não teve visão suficiente para imaginar um movimento perpétuo. (...) Na minha opinião, a mesma força e vigor subsiste sempre, passando somente de matéria em matéria, conforme as leis da natureza e a bela ordem preestabelecida.,

Outro importante crítico das idéias de tempo e espaço absolutos de Newton foi Ernst Mach. Notamos na sua visão muitas semelhanças com a proposta de Leibniz, exposta acima. Mach, em seu tratado sobre o desenvolvimento histórico da mecânica nega a possibilidade de um "tempo absoluto". Para ele, a própria idéia de tempo é uma abstração, à qual chegamos pela variação das coisas. Não podemos afirmar, por exemplo, que o movimento de um pêndulo ocorre no tempo. Percebemos esse movimento quando comparamos as sucessivas posições do pêndulo com outros pontos (na Terra, por exemplo). Ainda que esses pontos não existissem, a comparação dar-se-ia com nossos pensamentos e sensações, que seriam diferentes.

Da mesma maneira, um movimento só é uniforme quando comparado a outro movimento, também uniforme:

"A questão de que um movimento seja uniforme em si não tem nenhum sentido. Muito menos podemos falar de um "tempo absoluto" (independente de toda variação). Este tempo absoluto não pode ser medido por nenhum movimento, não tem pois nenhum valor prático nem científico; ninguém está autorjzado a dizer que sabe algo dele; não é senão um ocioso conceito "metafísico".,

Mais adiante, Mach afirma que a nossa representação do tempo surge a partir de uma correspondência entre o conteúdo de nossa memória e o conteúdo de nossa percepção.

Uma tentativa de criação de uma cosmovisão a partir das leis de Newton foi levada a cabo no século XVIII por Immanuel Kant (1724-1804), embora esse filósofo tenha sido também bastante influenciado por Leibniz. Como Descartes, Kant não nega a presença divina na criação do mundo. No entanto, é a atração gravitacional que fará

\footnotetext{
${ }^{50}$ LEIBNIZ, G.W. - Op. cit., p. 169.

${ }^{51}$ MACH, E. - Desarrollo Historico-Critico de la Mecanica, 1949.

${ }^{52}$ Ibid., p. 190. Tradução livre.
} 
surgir grandes corpos massivos, a partir da matéria espalhada por todo o espaço (infinito). À medida que mais matéria colapsa em direção aos centros que se vão formando, uma "força repulsiva" seria a responsável por desviar parte dela, gerando um movimento de rotação. ${ }^{53}$ Há muitos pontos interessantes em sua visão, inclusive alguns muito atuais, mas não iremos abordá-los aqui.

Para Kant, o tempo não existe fora de nós, mas é algo que utilizamos para descrever o mundo, é uma forma de nossa intuição. Em sua Crítica da razão pura, assevera-nos o autor:

"O tempo é uma representação necessária subjacente a todas intuições. Com respeito aos fenômenos em geral, não se pode suprimir o próprio tempo, não obstante se possa do tempo muito bem eliminar os fenômenos. O tempo é, portanto, dado a priori."

"O tempo nada mais é que a forma da nossa intuição interna. Se a condição particular da nossa sensibilidade lhe for suprimida, desaparece também o conceito do tempo, que não adere aos próprios objetos, mas apenas ao sujeito que os intui.'

Vemos com isso como Kant afasta-se também da concepção newtoniana de tempo, presente nos Principia. Mais adiante, apresenta suas "antinomias da razão pura", dentre as quais nos chama atenção aquelas onde o autor nega a possibilidade de um universo infinito espacialmente, bem como a de um início no tempo para o universo. Ele "prova" tanto essas teses quanto suas antíteses, e o faz por meio da "redução ao absurdo". Com relação a um possível início no tempo, nos diz ele:

"Com efeito, admita-se que quanto ao tempo o mundo não tenha nenhum início. Neste caso, até cada instante dado decorreu uma eternidade e, por conseguinte, transcorreu uma série infinita de estados sucessivos das coisas no mundo. Ora, a infinitude de uma série consiste precisamente no fato de ela jamais poder ser acabada mediante uma síntese sucessiva[*]. Logo, uma transcorrida série cósmica infinita é impossível e um início no mundo é, pois, uma condição necessária da sua existência. Este era o primeiro ponto a ser demonstrado.' *Martins chama à atenção que Kant refere-se ao fato de que a adição de um número finito a quantidades finitas não pode produzir um resultado infinito.

Mas Kant "prova" também que o universo não pode ter tido um início, sendo infinito em relação ao tempo:

\footnotetext{
${ }^{53}$ MARTINS, R. A. - Op. cit., p. 90-101.

${ }^{54}$ KANT, I. - Crítica da Razão Pura (coleção “Os Pensadores"), 1980, p. 44-45.

${ }^{55}$ Ibid., p. 223.
} 
"Com efeito, suponha-se que ele tenha um início. Visto que o início é uma existência à qual precede um tempo no qual a coisa não é, deve ter precedido um tempo em que o mundo não era, ou seja, um tempo vazio. Ora, num tempo vazio é impossível o surgimento de qualquer coisa, porque nenhuma parte de um tal tempo possui em si, preferencialmente a outra, uma condição distintiva da existência antes que a do não-ser (quer se admita que tal condição surja por si mesma ou através de uma outra causa). Logo, no mundo diversas séries de coisas podem realmente ter início, mas o mundo mesmonão pode ter nenhum início, e é por isso infinito com respeito ao tempo passado.,

Segundo Martins, a saída encontrada por Kant é assumir que a questão não foi bem colocada. Há um conflito nas proposições devido a uma ilusão, que se dissolve quando o tempo é pensado como forma a priori de nossa intuição, projetada sobre o mundo com o intuito de representá-lo.

Durante o século XVIII, articula-se a mecânica newtoniana sobre bases deterministas. Ainda que essa visão "mecanicista" afaste-se das idéias originais de Newton, como vimos, ainda hoje talvez seja a visão mais comum de seu trabalho. A idéia de que todo o passado e o futuro do universo estariam completamente determinados, que negava totalmente o acaso e o livre-arbítrio, foi defendida por Pierre S. Laplace (1749-1827), entre outros.

É nesse mesmo século, também, que inicia-se, com o aperfeiçoamento das primeiras máquinas a vapor, o processo que levará à revolução industrial e ao desenvolvimento da termodinâmica. Nesse contexto, teve importante papel o trabalho de James Watt (1736-1819), que aumentou o rendimento de máquinas anteriores, separando o condensador do cilindro aquecido.

Fugiria dos propósitos aqui expostos uma descrição pormenorizada das idéias de todos aqueles que contribuíram tanto para a formulação do princípio da conservação da energia, quanto das leis da termodinâmica, já no século XIX. Abordaremos, portanto, somente os aspectos relevantes para uma melhor contextualização da discussão sobre o tempo.

\footnotetext{
${ }^{56}$ Ibid., p. 223.
} 


\section{III.4. O TEMPO NO SÉCULO XIX: A CONSERVAÇÃO DA ENERGIA E A TERMODINÂMICA}

Com relação à idéia de um "princípio de conservação" na física, encontramos em Descartes e Huygens suas raízes mais sólidas. Segundo Souza Filho 57 , o primeiro acreditava na conservação do que veio a ser chamado "quantidade de movimento" $(m v)$, enquanto o segundo buscará a invariância de outra grandeza, conhecida posteriormente como "vis viva" $\left(m v^{2}\right)$. Paralelamente, muitas pessoas buscaram a construção de um "moto-perpétuo":

“(...) a ponto de em 1775 a Academia de Ciências de Paris não aceitar mais trabalhos sobre esse tema; e isto quase um século antes da formulação do princípio de conservação da energia.

Os trabalhos de J. R. Mayer, J. P. Joule e H. Helmholtz, em meados do século XIX, culminarão com a formulação do princípio de conservação da energia por esse último, em 1847, como conseqüência de um postulado sobre a impossibilidade do "moto-perpétuo".

Esse princípio é um dos mais fundamentais de toda a Física, assumido como válido tanto na mecânica clássica quanto na teoria quântica ou na relatividade. Ele expressa a homogeneidade do tempo, ou seja, o fato de que o tempo "flui" sempre no mesmo ritmo, num dado referencial. Dessa forma, um fenômeno físico (o resultado de uma desintegração radioativa, por exemplo) não muda, ao longo dos anos, se as condições iniciais permanecerem as mesmas. Podemos, em conseqüência disso, assumir, entre outras coisas, que uma determinada experiência não necessita ser repetida com o passar do tempo, pois seu resultado continua válido, consideradas as mesmas condições.

No entanto, se um pêndulo partisse espontaneamente do repouso e começasse a oscilar, isso em nada violaria o princípio da conservação da energia. Os chamados

\footnotetext{
${ }^{57}$ SOUZA FILHO, O. M. - Evolução da Idéia de Conservação da Energia - Um Exemplo de História da Ciência no Ensino de Física (Dissertação de Mestrado), IFUSP/FEUSP, 1987, p. 127*-137*.

${ }^{58}$ Ibid., p. $67 *$.

${ }^{59}$ Sobre a relação entre conservação da energia e homogeneidade do tempo ver: NUSSENZVEIG, H. M. Curso de física básica (vol. 1), $2^{\text {a }}$ edição, 1981, p. 391-395; e LANDAU, L. D. e LIFSHITZ, E. - Física Teórica (vol. 1), 1978, p. 38-41 e 52-54.
} 
"fenômenos irreversíveis", como a transformação de ovos em um omelete, poderiam não o ser, à luz desse princípio.

A formulação da segunda lei da termodinâmica também envolveu um longo trabalho de muitos pesquisadores. Aurani ${ }^{6}$ aponta a importância de J. Priestley, que descobriu o $\mathrm{O}_{2}$ em 1774, o que levou ao abandono (não por ele) da idéia de "flogístico". A. L. Lavoisier introduz a noção de "calórico" como "substância do calor" em 1789, e, em 1803, J. Black estabelece a diferença entre quantidade de calor e temperatura. Um dos primeiros a associar o calor à idéia de movimento, no entanto, foi o Conde Rumford, que em 1798 negou a possibilidade de existência de um "fluido calórico".

Sadi Carnot (1796-1832), motivado pelas profundas transformações que as máquinas térmicas começaram a operar, apresenta um estudo teórico sobre o funcionamento delas em 1824. Nesse trabalho, Carnot busca princípios gerais para o funcionamento das "máquinas de calor", estabelecendo condições de rendimento máximo (ciclo reversível ideal) e tecendo argumentos contra o "moto-perpétuo". Enuncia o que virá a ser a segunda lei da termodinâmica ao afirmar que a potência gerada nas máquinas deve-se ao transporte do calórico 62 de um corpo quente a um corpo frio.

Aurani aponta Rudolf Clausius (1822-1888) como o responsável por "matematizar" a segunda lei e formalizar o conceito de "entropia". Em seus trabalhos de 1856, 1862 e 1867 buscará uma ligação entre a idéia de conservação da energia e o seu "princípio" de que o calor não pode passar (espontaneamente) do corpo mais frio para o corpo mais quente (hoje conhecida como formulação de Clausius da $2^{\mathrm{a}}$ lei). Sua discussão sobre os processos cíclicos e não-cíclicos o levará a introduzir o conceito de entropia (que significa "transformação"), relacionando-o com as mudanças do "calor do corpo" e de sua "desagregação". Nos processos irreversíveis, há uma dissipação da energia no movimento caótico das partículas, o que não permite a conversão de todo o calor em trabalho mecânico, tornando uma parcela da energia inutilizável para esse fim, o que representa um aumento da entropia do sistema:

"Desse ponto de vista, entende-se o porquê de Clausius conferir a essa grandeza o significado de conteúdo de transformação: o conteúdo de transformação que a

\footnotetext{
${ }^{60}$ AURANI, K. - Ensino de Conceitos: Estudo das Origens da $2^{a}$ Lei da Termodinâmica e do Conceito de Entropia a partir do século XVIII (Dissertação de Mestrado), IFUSP/FEUSP, 1985.

${ }^{61}$ Essa hipótese parece ser mais antiga, estando presente em trabalhos de Robert Boyle.

${ }^{62}$ As "sutilezas" desse conceito em Carnot são discutidas por Aurani em sua dissertação.
} 
energia sofreu ao longo do processo, embora a transformação já pressuponha uma conservação no tempo.

A estreita relação entre energia e entropia a que Clausius se refere e que justifica a semelhança dos nomes, está em que ambas são ligadas às transformações (ou à conservação), uma representando qquilo que permanece inalterado e a outra registrando as mudanças ocorridas.

Clausius sintetiza dessa forma as suas conclusões:

“... se imaginarmos que a quantidade que denominei entropia de um corpo particular é formulada para todo o universo com as devidas considerações de todas as circunstâncias presentes, e se a isso incorporarmos o relativamente mais simples conceito de energia, podemos expressar os dois princípios fundamentais da teoria mecânica do calor para o universo na simples forma seguinte:

1. A energia do universo é constante.

2. A entropia do universo luta por atingir um valor máximo.,

A conclusão número 1 de Clausius, como vimos, não implica em um sentido preferencial para o transcorrer do tempo, mas relaciona-se à sua homogeneidade. A segunda conclusão, no entanto, aponta para uma "quebra de simetria", estabelecendo um sentido absoluto para esse transcorrer: do passado para o futuro. Ainda que haja uma diminuição "local" da entropia em certos processos, para sistemas isolados ela tende sempre a crescer.

A questão é que o universo pode ser considerado um sistema isolado. Sendo assim, a energia tenderia a dispersar-se cada vez mais pelo espaço infinito, as estrelas aos poucos deixariam de produzir luz e calor, e o universo caminharia para um estado final de equilíbrio conhecido como "morte térmica". Essa possibilidade, que além de preservar o determinismo sugere um certo "fatalismo", foi manifesta por muitos cientistas - como Lord Kelvin -, tendo influenciado filósofos e artistas no final do século XIX.

Kant já havia levado a idéia de irreversibilidade para o movimento dos astros, ao defender que o atrito oferecido pela superfície da Terra às correntes de maré, ocasionadas principalmente pela atração gravitacional da lua, acabaria por "frear" o movimento de rotação de nosso planeta. ${ }^{6.5}$

Boltzmann será o responsável por fornecer um tratamento estatístico do conceito de entropia. Trabalhou com o intuito de unir os princípios da mecânica com a termodinâmica, acabando por fundar a "mecânica estatística". Introduziu a noção de

\footnotetext{
${ }^{63}$ Ibid., p. 80.

${ }^{64}$ Apud AURANI, K. - Op. cit., p. 81.
} 
probabilidade em seus estudos sobre os processos reversíveis e irreversíveis, trazendo a irreversibilidade para o mundo microscópico. 66

A idéia de que o aumento da entropia em sistemas isolados é uma lei estatística, e não absoluta, faz com que exista uma probabilidade, ainda que infinitamente pequena, de fenômenos irreversíveis tornarem-se reversíveis: o omelete poderia transformar-se em ovos novamente!

É nesse âmbito que pode ser compreendido também o "paradoxo da reversibilidade", citado anteriormente. A "irreversibilidade macroscópica" dos sistemas dissipativos estaria relacionada a uma maior probabilidade de ocorrência de determinados estados microscópicos compatíveis com a evolução futura do sistema no sentido da entropia crescente, em contraposição a uma probabilidade quase nula de ocorrência de outros estados, correspondentes a um conjunto de condições iniciais preciso, que leve à "reversibilidade" ${ }^{67}$ Isso nos permite conjecturar que talvez não seja o tempo algo inevitável na natureza, mas, antes, uma possibilidade.

Tal idéia, de certa forma, poderia ser encarada como uma conjectura subjacente à proposta do "demônio de Maxwell", idealizada por James C. Maxwell em 1871. O "demônio" seria um ser capaz de violar a segunda lei da termodinâmica, fazendo passar calor do corpo mais frio para o corpo mais quente, a partir de seu possível conhecimento prévio sobre (por exemplo) o estado das moléculas de um gás. Manipulando uma porta divisória entre dois compartimentos com temperaturas diferentes, esse ser poderia deixar passar para o lado "mais frio" somente aquelas moléculas cuja energia cinética fosse inferior à media desse compartimento (tornando-o ainda mais "frio"), valendo o mesmo para o lado "mais quente".

Henri Poincaré acreditava na natureza probabilística da segunda lei. Numa tentativa de fugir à "morte térmica" do universo, defende ele que os sistemas, espontaneamente, podem "violar" essa lei:

\footnotetext{
${ }^{65}$ WHITROW, G.J. - Op. cit., p. 176.

${ }^{66}$ MATTOS, C. R. - Entrando na Era do Ensino de Entropia (Dissertação de Mestrado), IFUSP, 1991.

${ }^{67}$ SACHS, R. G. - Op. cit., p. 24-30. Ver também SALINAS, S. R. A. - História da Mecânica Estatística. Cadernos de História e Filosofia da Ciência, 1982, 3, p. 28-42.
} 
"De acordo com essa teoria, para ver o calor passar de um corpo frio para um quente, não será necessário ter uma visão acurada, a inteligência e a destreza do demônio de Maxwell; será necessário somente um pouco de paciência.'

Essa mesma idéia será retomada numa conferência proferida por Arthur Eddington à Sociedade de Matemática de Londres, em 1931.69

Friedrich Nietzsche (1844-1900) recusava-se também a aceitar a idéia de "morte térmica", recorrendo à conservação da energia para fundamentar seu conceito de "eterno retorno", segundo o qual os estados do universo repetem-se no tempo, cíclica e infinitamente:

“O mundo das forças não é passível de nenhuma diminuição: pois senão, no tempo infinito, se teria tornado fraco e sucumbido. (...) $O$ mundo das forças, portanto, nunca chega a um equilíbrio (...). Seja qual for o estado que esse mundo possa alcançar, ele tem de tê-lo alcançado, e não uma vez, mas inúmeras vezes. (...) Homem! Tua vida inteira, como uma ampulheta, será sempre desvirada outra vez e sempre se escoará outra vez, - um grande minuto de tempo no intervalo, até que todas as condições, gapartir das quais vieste a ser, se reúnam outra vez no curso circular do mundo. 70

O “demônio de Maxwell”, entretanto, parece não ser tão "demoníaco" assim. Segundo Mattos, L. Szilard e L. Brillouin mostraram, nesse século, que o demônio deve retirar alguma informação do sistema para que possa diminuir sua entropia. Utilizando o fóton como transmissor dessa informação, avaliaram o "custo entrópico" do processo, evidenciando a não-violação da segunda lei. Essas conclusões estão profundamente relacionadas com a teoria da informação, a noção de fractal, a teoria do caos, e a Biologia. Mais recentemente, pesquisadores em computação têm defendido que é o apagamento da informação que garante a não-violação da segunda lei, e não a obtenção da mesma.

O século XIX ainda assistirá a dois importantes desenvolvimentos, com reflexos sobre a visão de tempo físico.

Por um lado, o desenvolvimento do eletromagnetismo a partir dos trabalhos de Coulomb, Ampère, Oersted, Faraday, Hertz e Maxwell, entre outros, levará à noção de

\footnotetext{
${ }^{68}$ Apud MATTOS, C. R. - Op. cit., p. 62. Essa idéia é a base do chamado "paradoxo da recorrência", uma objeção levantada por E. Zermelo contra Boltzmann em 1896, a partir de um teorema matemático demonstrado por Poincaré. Sobre isso ver: SALINAS, S. R. A. - Op. cit., p. 38-40.

${ }^{69}$ MARTINS, R. A. - Op. cit., p. 128-130.

${ }^{70}$ NIETZSCHE, F. - O Eterno Retorno (coleção “Os Pensadores”), $2^{\mathrm{a}}$ edição, 1978, p. 389.

${ }^{71}$ MATTOS discute algumas dessas relações em sua dissertação.
} 
“campo". A “ação instantânea à distância" da mecânica newtoniana é substituída pela idéia de que uma informação só pode ser transmitida de um ponto a outro numa velocidade finita. No caso das ondas eletromagnéticas, essa velocidade é $c$.

Por outro, a descoberta da radioatividade natural propiciou uma exemplificação de um processo irreversível no nível atômico. Além disso, em breve ela seria utilizada para "medir o tempo", o que ajudou em muito a fundamentação da geologia e da teoria da evolução de Charles Darwin. Proposta em 1859, sua teoria esbarrava (também!) em objeções referentes ao tempo necessário para que a evolução tivesse ocorrido, avaliado por Darwin como sendo superior à idade estimada naquela época para o universo, tanto no âmbito religioso (tempo bíblico) quanto no pensar científico (algumas dezenas de milhões de anos).

O século XX nos brindará com duas "revoluções" na física: a da "mecânica quântica", que inaugura um novo olhar sobre o mundo, e a da "teoria da relatividade", que expande os horizontes da mecânica de Newton sob novas bases. Ambas terão reflexos sobre o pensamento cosmológico, bem como balançarão os alicerces da física construída até então. O conceito de tempo, como não poderia deixar de ser, é profundamente problematizado no bojo desse processo.

\section{III.5. O TEMPO NO SÉCULO XX: A RELATIVIDADE, A MECÂNICA QUÂNTICA E A COSMOLOGIA}

Embora Lord Kelvin acreditasse, ao final do século XIX, que poucas realizações restavam, no âmbito da física, para estabelecerem-se de modo definitivo as bases para uma compreensão plena da natureza, as "nuvens" que pairavam sobre o conhecimento físico transformaram-se em tempestade.

Por um lado, Albert Einstein (1879-1955) propõe, em 1905, a chamada teoria da relatividade especial, cujos "pilares" básicos são: o princípio da relatividade, segundo o qual as leis físicas são invariantes por uma mudança entre sistemas de referência

\footnotetext{
${ }^{72}$ WHITROW, G.J. - Op. cit., p. 175-178. O conceito de "tempo geológico" é bastante complexo, sendo sua construção histórica marcada por uma série de "obstáculos epistemológicos", alguns deles enfrentados por estudantes no processo de desenvolvimento dessa noção. A esse respeito ver: PEDRINACI, E. - La construcción histórica del concepto de tiempo geológico. Enseñanza de las Ciencias, 1993, 11 (3), p. 315323.
} 
inerciais; e a constância da velocidade da luz no vácuo, conforme medida por qualquer sistema de referência inercial.

Tais premissas são incompatíveis com as "transformações de Galileu" da mecânica newtoniana que, como vimos, pressupõem a existência de um tempo absoluto. Em sua substituição, a relatividade adotará as transformações de Lorentz (veja figura abaixo), por meio das quais o tempo passa a ser relativo, ou seja, a depender do sistema de referência do observador. Desse modo, os relógios de observadores que se deslocam, uns em relação aos outros, não marcarão a mesma coisa.

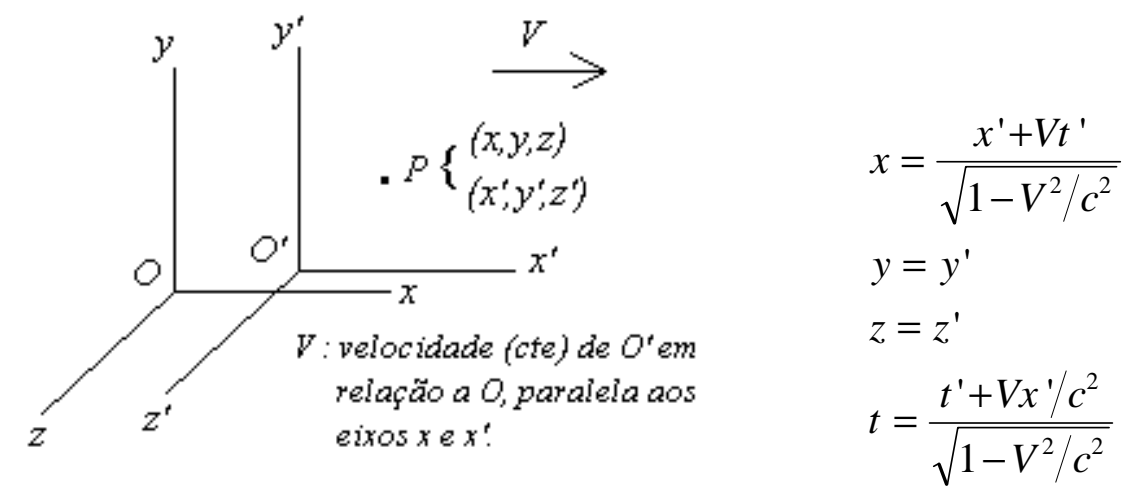

Para a questão que nos toca particularmente aqui, a relatividade trouxe, portanto, sérias e profundas implicações. A fusão do espaço e do tempo, na mesma medida em que relativizou essa última noção e, conseqüentemente, a de simultaneidade, tornandoas dependentes do observador, também incorporou novos absolutos, como a velocidade da luz e o "intervalo relativístico". Várias conseqüências surgem do tratamento matemático, como a chamada "contração do comprimento" e a dilatação do tempo". Posteriormente, com a teoria da relatividade geral, estabelece-se uma relação entre o transcorrer do tempo e a gravidade, de modo que quanto mais próximo um relógio estiver da Terra, por exemplo, mais lentamente ele trabalhará. Essa idéia está na base do famoso "paradoxo dos gêmeos".

\footnotetext{
${ }^{73}$ Uma interessante confirmação experimental dessas consequiências teóricas da relatividade é o caso dos múons originários de raios cósmicos, que são detectados na superfície da Terra, ainda que seus "tempos próprios" de decaimento não o permitissem. Ver: EISBERG, R. M. e LERNER, L. S. - Física: fundamentos e aplicações (vol. 2), 1982, p. 237-239.
} 
A segunda "revolução" na física desse século ocorreu com o advento da mecânica quântica, a nova teoria sobre o micromundo que rompeu, em muitos aspectos, com a ciência desenvolvida até fins do século XIX. A revolução quântica resultou do trabalho de um grande número de pessoas, dentre os quais poderíamos citar Planck, Bohr, Einstein, Born, Heisenberg, de Broglie, Schröedinger, Pauli, Dirac, Fermi, entre outros. Durante as primeiras décadas desse século, o novo olhar trazido pela mecânica quântica levou a uma série de questionamentos acerca do conhecimento físico desenvolvido até então. No âmbito mais filosófico, desestrutura-se o determinismo clássico, a relação sujeito-objeto, e problematiza-se a própria noção de objeto. Dualidades, incertezas e probabilidades são conceitos que ajudam a construir um novo saber, agora mais distante dos ideais da física clássica.

No tocante ao conceito de tempo, algumas idéias novas surgem do formalismo quântico, já a partir das relações de incerteza de Heisenberg. Para a energia e o tempo, a relação pode ser escrita como:

\section{$\delta E \delta t \geq \hbar / 2$}

Como aponta Osvaldo Pessoa Jr. ${ }^{74}$, houve historicamente diversas interpretações para essa desigualdade, o que gerou inclusive algumas confusões. Ainda hoje, entretanto, há várias formas de interpretá-la, que poderiam ser reunidas em cinco grupos diferentes (!). Não consideramos importante nesse ponto determo-nos sobre essas interpretações, mas apenas apontar que o tempo, na mecânica quântica, é um parâmetro numérico. A importância desse fato é que os "observáveis" são representados na teoria por "operadores" (como é o caso da posição, do momento, ou da energia), o que não ocorre com o "observável tempo", que não permite a definição de um "operador de tempo" auto-adjunto compatível com os autovalores do operador de energia, como Pauli mostrou na década de trinta. Ainda assim, alguns físicos vêm tentando explorar a idéia de um operador de tempo com autoestados não-ortogonais.

Uma outra questão que envolve a noção temporal na mecânica quântica diz respeito ao famoso debate Einstein-Bohr sobre os fundamentos dessa teoria. Einstein, descontente com o "status" que a probabilidade assumira no mundo quântico, encabeçou uma série de críticas à mecânica quântica, intencionando sempre demonstrar a

\footnotetext{
${ }^{74}$ PESSOA JR., O. - Uma Incerta História do Tempo na Física Quântica. In: ÉVORA, F. R. R. (org.) Espaço e Tempo, 1995.

${ }^{75}$ Ibid., p. 209 e 215-221.
} 
incompletude dessa teoria. Encontrou em Niels Bohr um adversário à altura, que soube articular a denominada "interpretação de Copenhague" (ou interpretação ortodoxa) para rebater as críticas einstenianas.

O debate teve o seu "clímax" em 1935, com a apresentação do paradoxo de EPR (Einstein, Podolsky e Rosen), cuja questão central é a análise de um sistema quântico que interagiu no passado e encontra-se agora separado por uma grande distância. A modificação de uma das partes desse sistema implicaria numa mudança instantânea da porção restante, o que significaria uma transmissão de informação a uma velocidade maior do que $c$, o que contradiz a teoria da relatividade. Esse efeito "não-local", como costuma ser denominado, lembra-nos a "ação instantânea à distância" da mecânica newtoniana, que também representava uma troca de informação com $\Delta \mathrm{t}=0$.

O ponto central dos argumentos de Bohr encontra-se no âmbito do significado da medição em mecânica quântica, e na interação dos objetos quânticos com os aparelhos de medida "macroscópicos". Poderíamos dizer, quem sabe, que se travou de certo modo um "diálogo de surdos", que se encerrou com a morte de Einstein em 1955. Trabalhos posteriores retomaram a questão colocada por EPR, tanto teórica quanto experimentalmente, mostrando que o tipo de correlação não-local entre dois sistemas é compatível com o formalismo quântico, e ocorre de fato na realidade.

Interessa-nos também aqui a asserção de que, embora representem revoluções no que se refere à física clássica como um todo, tanto a teoria da relatividade quanto a mecânica quântica são teorias reversíveis temporalmente, ou seja, cujas estruturas matemáticas não distinguem $t$ de $-t$. Essa equivalência, que já estava presente na mecânica de Newton, continua portanto fazendo parte das equações mais fundamentais da física. Seria oportuno apontar, inclusive, que as "antipartículas" podem ser interpretadas como "partículas" viajando para trás no tempo.

Recentemente, entretanto, diversos autores têm retomado essa discussão sobre a possibilidade de introdução da irreversibilidade no mundo "microscópico". Essa tentativa encontra suas raízes no século XIX, com a fundação da mecânica estatística

\footnotetext{
${ }^{76} \mathrm{O}$ paradoxo pode simplesmente desaparecer se imaginarmos, como sugeriu-me o prof. Manoel R. Robilotta, que não se trata de "dois objetos" separados, mas do mesmo objeto quântico. Como vemos, a própria noção de objeto é um ponto polêmico.

${ }^{77}$ Há diversos trabalhos a esse respeito, como afirmam COVENEY, P. e HIGHFIELD, R. - A Flecha do Tempo, 1993, p. 120 (nota 61).

${ }^{78}$ Quanto a esse último ponto, ver COVENEY, P. e HIGHFIELD, R. - Op. cit., p. 122 (nota 69).
} 
com o trabalho de Boltzmann e outros, como vimos. O estudo recente dos sistemas dissipativos e da termodinâmica longe do equilíbrio trouxe novas idéias para o centro desse debate. Os "defensores da irreversibilidade" lineares que regem tais sistemas introduzem uma "flecha do tempo", e que há correlações (no nível microscópico) que permitiriam descrever de forma assimétrica (em relação ao tempo) os sistemas mais elementares tratados pela mecânica estatística 80

Além disso, os chamados "sistemas caóticos", nos quais variações mínimas das condições iniciais modificam toda a evolução futura dos mesmos, levariam a um rompimento com o determinismo "estrito" da mecânica clássica. A previsibilidade acerca do comportamento de sistemas como esses estaria limitada a um "horizonte temporal', dentro do qual as possíveis trajetórias seriam indistinguíveis dentro do grau de precisão possível das medidas.

No que se refere à mecânica quântica, os defensores dessas teses argumentam que o processo de medida, e o correspondente colapso da função de onda, introduzem de modo definitivo e inevitável a irreversibilidade no sistema quântico. 1 .

A física deste século proporcionou uma revolução não apenas no "micromundo", mas levou à formulação de novas teorias sobre o universo como um todo. Com o advento da teoria da relatividade geral de Einstein, assistiremos a um desenvolvimento sem precedentes da cosmologia. Seria difícil tentarmos resgatar aqui todos os modelos surgidos nesse âmbito que, entretanto, interessar-nos-ão na medida em que apontem ou não para um "início temporal”, ou sugiram concepções novas sobre o tempo.

Os primeiros modelos matemáticos para o universo, que utilizavam a teoria da relatividade geral, foram elaborados por Einstein, W. de Sitter e A. Friedmann. 82 Os dois primeiros propuseram um "universo estático", onde não haveria um "início". Nessa formulação, Einstein foi obrigado a introduzir a chamada "constante cosmológica" para escapar do "colapso gravitacional" decorrente de seu modelo. Tal solução (ad hoc) foi abandonada posteriormente. Já Friedmann mostrou, em 1922, que existiam diversas soluções compatíveis com a teoria da relatividade geral e que representavam universos

\footnotetext{
${ }^{79} \mathrm{O}$ maior expoente dessa vertente atual é sem dúvida Ilya Prigogine.

${ }^{80}$ PRIGOGINE, I. e STENGERS, I. - Entre o Tempo e a Eternidade, 1992; e COVENEY, P. e HIGHFIELD, R. - Op. cit..

${ }^{81}$ COVENEY, P. e HIGHFIELD, R. - Op. cit., principalmente capítulos 4 e 8.
} 
não-estáticos. Esse resultado teórico surgiu poucos anos antes da descoberta do astrônomo Edwin Hubble de que quase todas as galáxias estão afastando-se de nós, com velocidades proporcionais à distância. Tal "evidência" experimental em favor da expansão do universo 83 procurou então ser incorporada a novas teorias relativísticas propostas no final da década de vinte por G. Lemaître e A. Eddington. 84

A física nuclear e a cosmologia desenvolvem-se paralelamente, e uma explicação do surgimento dos elementos químicos e sua proporção atual no universo passam a ser questões "cosmológicas". Surge então em 1947, com G. Gamow, a chamada teoria do "big bang", que procurou dar respostas às indagações expostas acima. Esse modelo foi mais e mais articulado a partir de então, mas certamente poderíamos dizer que suas idéias centrais constituem, ainda hoje, a visão dominante em cosmologia.

O big bang representa uma grande explosão que teria originado, há cerca de 15 bilhões de anos, o nosso universo. A partir de então, iniciou-se a expansão que presenciamos ainda hoje. A quantidade total de matéria existente no universo (que ainda é uma incógnita) é um dado fundamental para que se possa prever o seu futuro, ou seja, se a expansão continuará indefinidamente ou se haverá um recuo, um colapso gravitacional até o (já) denominado big crunch. Mas essa é apenas uma das questões ainda em aberto para essa teoria. Outro aspecto interessante é a singularidade presente em $\mathrm{t}=0$, ou seja, no instante do surgimento do universo. Nesse ponto haveria uma densidade infinita de matéria, o que representa um problema matemático para a teoria, que deixaria de ser válida no big bang. ${ }^{8}$ Poderíamos considerá-lo "o início do tempo"? Se a resposta for sim, estaria a cosmologia colocando-nos uma questão análoga à de Santo Agostinho: o que existia antes?

Contemporâneo ao modelo do big bang, surge em 1948 o "modelo do universo estacionário", que propunha um universo infinito no tempo e no espaço, mas com criação contínua de matéria entre as galáxias, na medida em que elas expandem-se. Mas a descoberta da "radiação cósmica de fundo" na década de sessenta acabou fortalecendo a teoria do big bang, uma vez que esse dado experimental compatibilizava-se com as

\footnotetext{
${ }^{82}$ MARTINS, R. A. - Op. cit., p. 137-139.

${ }^{83}$ Paul A. M. Dirac propôs, em 1937, que as próprias leis físicas poderiam variar com o tempo. Nesse caso, "mensagens" das estrelas, como o "desvio para o vermelho" da lei de Hubble, podem não significar o que imaginamos, pois foram enviadas numa outra época. Um pouco mais sobre isso encontra-se em MARTINS, R. A. - Op. cit., p. 174-175.

${ }^{84}$ Ibid., p. 144-146.
} 
previsões dessa teoria, sendo uma espécie de "resquício arqueológico" da grande explosão inicial.

Problemas quanto à homogeneidade do universo levaram a uma nova articulação da teoria do big bang, conhecida como modelo do universo inflacionário, proposto por A. Guth em 1981, e que pressupunha uma repentina expansão do espaço nos instantes iniciais do universo (algo como um big bang "dentro" do big bang). Com ele, buscou-se compreender de que modo o universo poderia ser tão homogêneo (quanto à temperatura, distribuição da radiação de fundo, e outras propriedades físicas) se, em seu início, não haveria tempo suficiente para uma efetiva comunicação entre suas diversas partes (dada a limitação imposta pela velocidade da luz). Por outro lado, descobertas observacionais dos quasares, aglomerados e super-aglomerados de galáxias evidenciavam que o universo não é tão homogêneo quanto se imaginava, no que se refere à distribuição de matéria.

Ainda na década de oitenta busca-se o auxílio da mecânica quântica (devido aos fortes campos gravitacionais envolvidos) para a compreensão da relação entre a estrutura atual do universo e o big bang: a existência de "flutuações quânticas" na "sopa" primordial, que teriam sido transmitidas para todo o universo no período inflacionário, corresponderiam às regiões onde, posteriormente, a matéria aglutinou-se para formar os super-aglomerados e aglomerados galáticos. Essas espécies de "sementes cósmicas" deixaram seus "rastros" na radiação cósmica de fundo, na forma de uma anisotropia detectada já nessa década pelo satélite COBE (sigla para Cosmic Background Explorer).

Uma teoria completa e unificada da gravitação e da mecânica quântica, entretanto, ainda não foi alcançada. Segundo Stephen Hawking, tentativas nesse sentido podem levar à introdução de um tempo imaginário, o que desapareceria completamente com a distinção entre espaço e tempo, num espaço-tempo euclidiano, finito em extensão, mas sem fronteiras ou limites. A "vantagem" de uma análise desse tipo seria a exclusão de

\footnotetext{
${ }^{85}$ HAWKING, S. W. - Breve História do Tempo, 4 a edição, 1996, p. 76-77 e p. 168.

${ }^{86}$ SMOOT, G. e DAVIDSON, K. - Dobras no Tempo, 1995. Sobre o período inflacionário, ver o capítulo 9.
} 
certas singularidades. O universo teria então uma história segundo o tempo imaginário, e outra (correspondente, mas com um aspecto diferente) segundo o tempo real. ${ }^{87}$

O "modelo cosmológico padrão" (ou simplesmente "modelo padrão"), que representaria a atual teoria do big bang, convive com outras possibilidades teóricas, advindas do estudo das geometrias possíveis para o estabelecimento de um modelo de universo. Dentre elas, há algumas que permitiriam a existência (em configurações bastante particulares) de "curvas do tipo-tempo fechadas" (ou CTC, do inglês closed timelike curve), representando uma alternativa teórica científica para um "retorno ao passado". 8.8 Não nos atreveremos a tentar aprofundar essa discussão aqui, que certamente requer um conhecimento profundo tanto de topologia como de relatividade geral.

Outras abordagens defendem que a criação de matéria a partir de flutuações quânticas de um "vácuo primordial" (com energia total nula) representaria um processo entrópico. Essa interpretação, que busca trazer a irreversibilidade e a chamada "flecha do tempo" para os instantes iniciais do universo, pretende unir aspectos de diferentes visões (o modelo padrão e o modelo do universo estacionário), levando a uma (nova) idéia de tempo "absoluto", que precederia toda a existência, marcada por universos que "nascem e morrem",

Início do tempo, tempo imaginário, retorno ao passado, flecha do tempo. Como vemos, a questão do tempo na cosmologia moderna não se encontra apenas em aberto, mas é o "olho" de um furacão teórico que pode arrastar a física por distintos caminhos. As teorias mais fundamentais e atuais da ciência ainda encontram, no tempo, um profundo mistério.

Finalizando essa seção, seria importante apontarmos que para o cidadão comum contemporâneo, no entanto, desfaz-se (infelizmente) essa "poética" do tempo, que estivemos a garimpar ao longo desse capítulo, e lapidaremos (uma pequena parte) no seguinte. A "marcação do tempo" por meio de relógios mais e mais precisos, vinculada a questões de ordem econômica e social, acrescida de um sistema de comunicação cada

\footnotetext{
${ }^{87}$ HAWKING, S. W. - Op. cit., p. 182-191. É importante esclarecer que "tempo imaginário" é um conceito bem definido matematicamente, pois refere-se aos números complexos.

${ }^{88}$ Os requisitos e as implicações dessas alternativas teóricas são discutidos em NOVELLO, M. - $O$ Círculo do Tempo, 1997. Ver também COVENEY, P. e HIGHFIELD, R. - Op. cit., p. 90-92.
} 
vez mais interligado e rápido, acabou por tornar o tempo o grande "senhor" da vida das pessoas. Uma pretensa "domesticação" do tempo pela ciência, representada pela própria definição do segundo no sistema internacional de unidades (SI) - duração de 9.192.631.770 períodos de oscilação da radiação correspondente à transição entre dois níveis hiperfinos do Césio-133 - parece corresponder plenamente ao papel que esse conceito adquiriu em nossa sociedade industrial moderna. Whitrow descreve em seu livro alguns pormenores de aspectos sociais do recente desenvolvimento científico e tecnológico do problema da "marcação do tempo". "Infelizmente não podemos aqui abordar esse ponto em profundidade.

${ }^{89}$ PRIGOGINE, I. e STENGERS, I. - Op. cit., capítulo 7.

${ }^{90}$ WHITROW, G. J. - Op. cit., p. 178-189. 


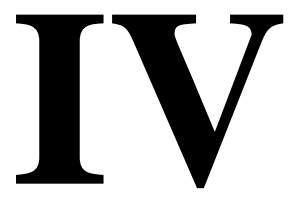

Refazendo para nós mesmos imagens do cubículo do filósofo meditando, vemos sobre a mesma mesa a vela e a ampulheta, dois seres que medem o tempo humano, mas em estilos bem diferentes! A chama é uma ampulheta que escorre para o alto. Mais leve do que a areia que desmorona, a chama constrói sua forma, como se o próprio tempo tivesse sempre alguma coisa a fazer.

Gaston Bachelard (em "A Chama de uma Vela") 


\section{O "EXEMPLAR"}

Nesse último capítulo procuraremos efetuar uma espécie de "síntese" do que foi apresentado até aqui, buscando incorporar elementos dos três primeiros capítulos.

A "perspectiva histórica", decorrente de nossas discussões epistemológicas e educacionais, ainda não se encontra contemplada plenamente no capítulo que acabamos de encerrar, por tratar-se de uma "visão preliminar", uma apresentação de concepções sobre o tempo, fruto de nossa pesquisa sobre esse tema. Para transformarmos esse estudo numa história que não seja meramente "ilustrativa", factual e cronológica, necessitamos agora incorporar os elementos epistemológicos discutidos inicialmente. Traremos então de volta Kuhn, Bachelard e Feyerabend, no intuito de problematizar um determinado período histórico, promovendo um novo olhar sobre ele, e aprofundar nossa análise.

Selecionamos, com essa intenção, o período compreendido entre os séculos IV a.C. e XVII d.C., aproximadamente. Nosso propósito será o de analisar como o conceito de tempo foi introduzido de forma definitiva no estudo dos movimentos.

Para nós, o texto a seguir pode ser considerado um "episódio" de história da ciência, um "exemplar" que visa ser o resultado dessa tripla união: epistemologia científica, história da ciência, concepção de educação. Isso porque acreditamos haver produzido um texto que vai ao encontro do que foi almejado no capítulo II em termos do ensino de física, e que pode ser utilizado pelo professor de ciências, seja em sua

formação profissional, seja como subsídio para a elaboração de suas aulas, um "veículo problematizador" do conteúdo a ser debatido, dialogado.

\footnotetext{
${ }^{1}$ Pensamos aqui principalmente - mas não unicamente - no ensino médio.
} 


\section{O TEMPO NA MECÂNICA: DE COADJUVANTE A PROTAGONISTA}

- Que sucedeu? - perguntou Fogg.

- Senhor... - balbuciou Fura-Vidas. Casamento... impossível.

- Impossível?

- Impossível... para amanhã.

- Por quê?

- Porque amanhã... é domingo.

- Segunda-feira - replicou Fogg.

- Não... hoje... é... sábado...

- Sábado? Impossível!

- Sim, sim, sim! - começou a gritar Fura-Vidas. O senhor enganou-se num dia! Chegamos vinte e quatro horas antes... Mas agora não restam mais que... dez minutos.

Julio Verne

Para nós, que temos na Filosofia do Não de Bachelard um dos principais referenciais teóricos no campo epistemológico, nada mais natural, talvez, do que iniciarmos essa seção a partir de um erro. Galileu, ao estabelecer a lei de queda dos corpos, busca primeiramente relacionar a variação de velocidade dos corpos em queda com a distância percorrida a partir da origem, e não com o intervalo de tempo correspondente. Esse "erro", em que Galileu assume ter incorrido (nos Discorsi) durante certo tempo, também foi cometido por Descartes, como aponta Alexandre Koyre ${ }^{3}$. Por que dois "monstros" da ciência haveriam de titubear para introduzir o tempo no estudo do movimento de queda? Uma resposta satisfatória a essa questão só poderá emergir se conseguirmos compreender o trabalho de ambos no âmbito de uma revolução científica, no sentido kuhniano da expressão.

Galileu, que será objeto mais direto de nossa análise, é um protagonista dessa revolução que, essencialmente, representou a transição entre dois paradigmas: do aristotélico-ptolomaico para o newtoniano. E é justamente por isso que necessitamos, inicialmente, adentrar no "universo conceitual" do primeiro paradigma. Somente dessa forma poderemos entender a natureza e o porquê da revolução, a relevância e a razão do

\footnotetext{
${ }^{2}$ VERNE, J. - A Volta ao Mundo em 80 Dias, 1970, p. 196.
} 
erro galileano, e a ruptura existente entre as "visões de mundo" representadas por esses paradigmas, em geral, e entre os "conceitos" de tempo a eles associados, em particular.

Foi no âmbito da astronomia que os mais duros golpes foram desferidos contra a cosmologia aristotélica. O universo heliocêntrico de Nicolau Copérnico veio, no século XVI, contribuir não apenas para uma completa reformulação da astronomia, sob novas bases, como também para uma profunda transformação na visão do homem e de seu papel no universo. Thomas S. Kuhn, no seu livro A Revolução Copernicana (que será a "linha mestra" dessa seção), fala-nos um pouco do impacto da proposta heliocêntrica:

"Iniciada como uma revisão pouco técnica e altamente matemática da astronomia clássica, a teoria de Copérnico tornou-se um foco das tremendas controvérsias de religião, filosofia e teoria social, que, durante os dois séculos seguintes à descoberta da América, determinaram o teor do espírito moderno. Homens que acreditavam que o seu local terrestre era só um planeta que circulava cegamente por entre uma infinidade de estrelas avaliavam esse local no esquema cósmico dum modo muito diferente do dos seus predecessores, que viam a Terra como um centro único criado por Deus. A Revolução Copernicana foi, por isso, também parte de uma transição na escala de valores do homem ocidental.

Tratava-se o universo herdado pelos contemporâneos de Copérnico de um "mundo fechado". Suas raízes encontram-se por volta do século IV a.C. na Grécia, onde consolidou-se a visão de que a Terra era esférica e encontrava-se imóvel no centro do universo. Em seu redor circulavam, presos a esferas, a lua, o sol, os demais planetas (Mercúrio, Vênus, Marte, Júpiter e Saturno - visíveis a olho nu e conhecidos desde a antigüidade) e, por último, as estrelas. Além delas não existia nada: nem espaço, nem matéria.

A esfera fora escolhida por ser a mais perfeita figura da geometria, sendo por isso a melhor opção de que dispunha o Criador para construir o mundo. Essa concepção aparece no Timeu, de Platão, onde (lembremos) nos diz o autor que o tempo foi criado junto com o universo, como "uma imagem móbil da eternidade". Entretanto, havia também outras razões de natureza observacional que sustentavam a esfericidade da Terra, como o formato da sombra projetada por essa durante um eclipse lunar ou a

\footnotetext{
${ }^{3}$ Conforme expresso na seção II.1. de nosso trabalho (p. 57).

${ }^{4}$ KUHN, T. S. - A Revolução Copernicana, 1990, p. 20.

${ }^{5}$ PLATÃO - Diálogos (Vol.XI - Timeu), 1977, p. 50.
} 
maneira pela qual os navios desapareciam no horizonte (primeiramente o casco e, por fim, o mastro).

Quanto à imobilidade da Terra, nossos próprios sentidos atestam a seu favor, enquanto o sol e as estrelas parecem caminhar no céu durante o dia e a noite, circundando-nos. Esse é um ponto importante, uma vez que o argumento dos sentidos somou-se a motivações teóricas, estéticas e religiosas para sustentar, durante séculos, o modelo cosmológico em questão.

Aristóteles (384-322), no De caelo, justifica a esfericidade dos céus e a imobilidade da Terra da seguinte forma, como aponta W. D. Ross:

"A atividade de Deus é a vida eterna. Portanto o movimento do céu, que é um corpo divino, deve ser eterno, e por esta razão o céu deve ser uma esfera rotativa. Mas o centro de um corpo rotativo pstá em repouso. Deve haver, pois, uma terra em repouso no centro do universo. ${ }^{, 6}$

O universo esférico e geocêntrico explicava de modo bastante satisfatório uma série de movimentos observados no céu, como o chamado "movimento diário" do sol e das estrelas (de leste para oeste) e o movimento "para norte" e "para sul" do sol, com o passar das estações, além dos eclipses. Havia também uma justificativa para a "ordem" dos astros a partir da Terra (lua, Mercúrio, Vênus, sol, Marte, Júpiter, Saturno e estrelas), uma vez que quanto maior a proximidade com a última esfera, menor era o "atraso" para leste (em relação às estrelas) verificado ao longo do tempo no movimento do astro em questão, que era um movimento observado na prática.

No entanto, os planetas apresentavam movimentos mais complexos, conhecidos como movimentos retrógrados. Pareciam "errar" pelo céu noturnơ, interrompendo por um certo período o seu movimento para leste e avançando para oeste, retrocedendo novamente em seguida. Tais movimentos desafiaram desde cedo os articuladores do universo geocêntrico. Dentre eles, Eudoxo e Calipo, ainda no século IV a.C., estabeleceram um sistema de esferas homocêntricas no qual cada planeta pertencia não a uma, mas a um conjunto de armações esféricas concêntricas e interligadas. Embora bastante sofisticado, esse sistema não explicava adequadamente as variações de brilho observadas nos planetas, sendo abandonado pelos astrônomos em detrimento de uma

\footnotetext{
${ }^{6}$ ROSS, W. D. - Aristoteles, 1957, p. 140. Tradução livre.

${ }^{7}$ Daí o próprio nome de "planeta", que significa "astro errante" (em grego).
} 
outra concepção geométrica mais satisfatória: o sistema de epiciclos e deferentes, desenvolvido por Apolónio e Hiparco entre os séculos III e II a.C.. Nele, um certo planeta era posto a circular sobre uma pequena esfera (o epiciclo), cujo centro girava sobre uma circunferência maior (o deferente), conforme indica a figura abaixo:

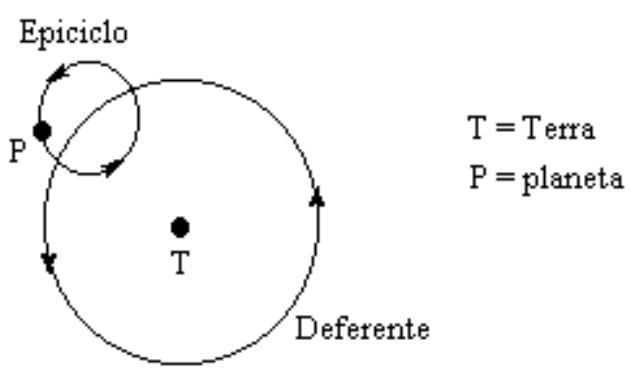

Figura 1: o sistema epiciclo-deferente.

Já no século II a.C., Ptolomeu será responsável por uma grande "síntese" da astronomia grega desenvolvida até então, e sua obra Almagesto revela uma série de outros "artifícios" geométricos que foram utilizados pelos astrônomos na tentativa de adequar o modelo com as observações das posições planetárias. Além de epiciclos e deferentes, havia epiciclos menores, excêntricos (círculos cujos centros estariam deslocados do corpo em torno do qual ocorria o movimento) e equantos (pontos também deslocados do centro geométrico do deferente, mas em torno do qual a velocidade de rotação do mesmo deveria ser uniforme), como representado abaixo:

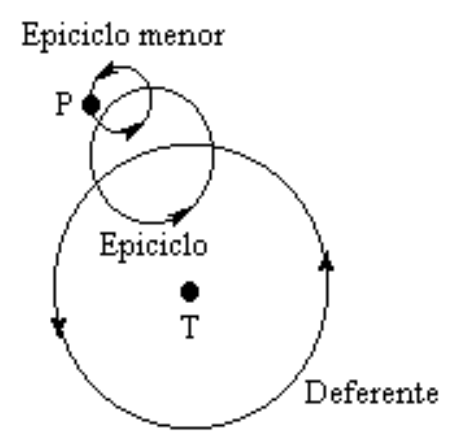

(a)

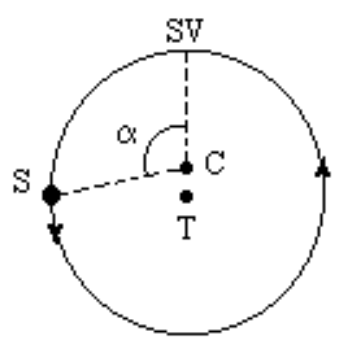

(c)

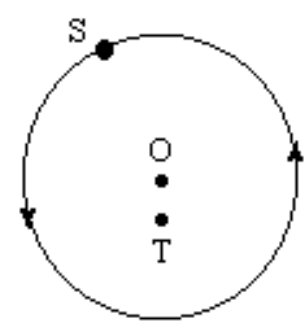

(b)

$$
\begin{aligned}
& \mathrm{T}=\text { Terra } \\
& \mathrm{P}=\text { planeta } \\
& \mathrm{S}=\text { sol } \\
& \mathrm{O}=\text { centro do excêntrico } \\
& \mathrm{C}=\text { ponto equanto } \\
& \mathrm{SV}=\text { solstício de verão } \\
& \alpha=\text { ângulo que varia uniformemente } \\
& \quad \text { com o tempo }
\end{aligned}
$$

Figura 2: (a) epiciclo menor; (b) excêntrico, e (c) equanto. 
O importante nesse ponto é percebermos como o problema das posições planetárias acabou levando os astrônomos da antigüidade a construírem um modelo cada vez mais aprimorado e "geometrizado" do universo, numa tentativa de "salvar" a esfera, conciliar "observação" e "sentidos". Resgatando novamente os conceitos kuhnianos, esferas homocêntricas, epiciclos, deferentes etc representariam a articulação de um paradigma numa prática identificada com a "ciência normal". Na medida em que, como veremos a seguir, o modelo aristotélico-ptolomaico vinculava-se a uma teoria do movimento e da constituição material do universo, sendo ainda incorporado e adaptado por um sistema religioso, tornou-se cada vez mais difícil romper com essa visão de mundo. É nesse sentido, de um corpo de conhecimentos articulado, coeso, estruturado, explicativo de uma certa "ordem das coisas", que podemos falar em "paradigma”. E é aí que é necessário que entremos, para que conceitos como "revolução" e "incomensurabilidade" possam ter alguma significação quando emergirmos.

Embora o sistema de Ptolomeu não conseguisse ajustar-se fielmente às observações, dominou como modelo astronômico (no que se refere à previsibilidade das posições dos astros) durante quase 1800 anos. Entretanto, foi o sistema de esferas homocêntricas que acabou por ser incorporado à cosmologia aristotélica, permanecendo em parte aceito durante todo esse período. Dessa forma, a realidade ontológica das armações esféricas poderia ser descartada por alguns, que lhes imputavam uma "realidade metafórica". 8

A cosmologia aristotélica separava rigidamente o universo, finito, em duas regiões distintas: o mundo supralunar ou celeste, que se estendia a partir da esfera da lua até a última esfera (das estrelas), e o mundo sublunar ou terrestre, situado abaixo da esfera lunar, que continha a Terra. O mundo supralunar era constituído de "éter", um sólido cristalino puro, inalterável e sem peso, compatível com a eternidade, perfeição e imutabilidade dos céus. As esferas eram consideradas espessas o suficiente para que o movimento dos astros em seu interior pudesse explicar as variações de brilho observadas. O movimento circular de cada esfera, a partir das estrelas, era transmitido às demais, até à lua.

\footnotetext{
${ }^{8}$ KUHN, T. S. - Op. cit., p. 79 e 101-102. Essa não parece ser a posição de Aristóteles, para quem as esferas eram reais. Ver ROSS, W. D. - Op. cit., p. 143.
} 
Enquanto isso, o mundo sublunar constituía-se de quatro elementos fundamentais, também ordenados em esferas a partir do centro do universo: terra, água, ar e fogo. Todas as substâncias presentes na Terra eram geradas a partir da mistura desses elementos em proporções variadas, o que era causado pelo movimento dos céus, uma vez que a fronteira da esfera lunar empurrava camadas de fogo, gerando correntes que impeliam e misturavam os demais elementos, no mundo sublunar. Os céus, embora separados da Terra, seriam os responsáveis pelas mudanças e corrupções à nossa volta.

De modo compatível e complementar ao exposto acima, na concepção aristotélica do movimento terrestre há a necessidade de uma "força" para que os corpos sejam alijados de suas "posições naturais", às quais tendem a retornar, uma vez que a força cesse. O movimento "para cima" e "para baixo" nada mais é, portanto, do que a atualização de uma potência. De tal sorte que uma pedra, lançada verticalmente para cima, tende a regressar ao solo, num movimento de retorno ao seu "lugar natural", o centro da Terra e do universo. Esse ponto é crucial para compreendermos a importância do espaço na visão de mundo aristotélica, pois mesmo que a Terra fosse deslocada de sua posição atual, ainda assim a pedra mover-se-ia para o ponto geométrico considerado o centro do universo. Portanto, o centro da terra "coincide" com o do universo, e esse argumento reforça ainda mais a esfericidade e imobilidade da Terra.

O espaço não é, entretanto, separado da matéria que o preenche. No mundo de Aristóteles não há vácuo, e o espaço é um pleno de matéria que, por ser contínua, pode ser infinitamente dividida sem que se chegue a um limite. Essa é, ao mesmo tempo, a idéia de pleno e uma negação do vazio.

Mas como situa-se a questão do tempo na cosmologia aristotélica? Adentramos aqui, certamente, em um ponto de grande interesse para a perspectiva colocada por nosso trabalho. Em sua obra sobre Aristóteles, W. D. Ross aponta que o tempo é, na concepção desse filósofo, infinito em dois sentidos: do ponto de vista da adição, ou seja, não pode esgotar-se por nenhuma adição de partes, e do ponto de vista da divisão, ou seja, é divisível ad infinitum. O "infinito temporal" não existe, entretanto, simultaneamente, uma vez que cada parte desaparece, embora não deixe de haver outras. ${ }^{6}$ Como aponta Ross:

\footnotetext{
${ }^{9}$ A própria impossibilidade de um começo e um fim para o tempo é um argumento em favor da idéia de infinito. Ver ROSS, W. D. - Op. cit., p. 124-125.
} 
"O tempo não existe como um todo dado infinito, pois não está na natureza de suas partes coexistir; mas, diferente da extensão, o tempo é potencialmente infinito desde o ponto de vista da adição. O tempg, como a extensão, é infinitamente divisível, mas não infinitamente dividido."

Podemos ver como o universo finito de Aristóteles não o permite atribuir à "extensão" a possibilidade de infinitude quanto à adição. Por outro lado, é clara a ênfase ontológica dada ao presente, na concepção de tempo exposta acima.

O tempo é, também, contínuo, pois está ocupado por um movimento contínuo. E o movimento, por sua vez, é contínuo porque dá-se através de um espaço contínuo. Dessa forma, a idéia de "anterior" e "posterior" relaciona-se com o espaço, com o movimento, e em terceiro lugar, com o tempo. Em relação a esse, podemos distinguir um "antes" e um "depois", ou seja, dois "agoras" com um intervalo (contínuo) entre eles. Esses "agoras" não seriam as menores partes do tempo, assim como os pontos não são as menores partes de uma linha. Aristóteles relaciona o tempo ao movimento em geral, afirmando que o tempo é o aspecto numerável do movimento, o número do movimento com respeito ao "antes" e "depois" tempo e o movimento definem-se um ao outro.

O movimento dos céus, portanto, por ser circular, regular e imutável, forneceria uma medida perfeita desse tempo contínuo ao mesmo tempo em que faz com que o próprio tempo seja contínuo, o que nos lembra a visão platônica de um tempo "produzido" pela rotação das esferas celestes. Além disso, por ser um movimento eterno, tal visão poderia implicar num tempo infinito, aqui no sentido de "tendo sempre existido". Esse último aspecto já afasta a concepção aristotélica de Platão, e será modificado com a incorporação da obra de Aristóteles ao cristianismo.

Um outro ponto importante, assinalado por Ross, é o fato de Aristóteles questionar-se se o tempo poderia existir na ausência da alma, ou seja, de alguém que possa “contar". Nessa hipótese, o tempo em si não existiria, mas apenas o movimento (que é seu "substrato"), sem aspecto mensurável. 12

Há diversas considerações a fazer a partir dos últimos parágrafos, que situam a questão temporal na cosmologia aristotélica. Primeiramente, parece-nos claro, a essa

\footnotetext{
${ }^{10}$ Ibid., p. 126. Tradução livre.

${ }^{11}$ Ibid., p. 132-133.

${ }^{12}$ Ibid., p. 134.
} 
altura, o caráter "secundário" que o tempo assume dentro desse paradigma. O movimento não é relativo ao tempo, embora esse seja seu aspecto mensurável, mas ao lugar. No universo aristotélico os lugares estão bem determinados, numa rígida hierarquia de um mundo fechado, e o privilégio é do espaço-matéria. O tempo é um coadjuvante, que aparentemente desapareceria com a ausência do homem.

A importância do espaço é discutida por Kuhn quando assevera que esse conceito, na concepção aristotélica, difere radicalmente do espaço newtoniano. Esse último caracteriza-se pela homogeneidade e isotropia, de modo que é fisicamente neutro, não existindo nenhuma região ou direção preferencial para o movimento. Por outro lado, o primeiro caracteriza-se por uma diferenciação de lugares que atuam ativamente no movimento dos corpos. Como coloca Kuhn:

"O próprio espaço fornece o impulso que leva o fogo e as pedras para os seus lugares naturais de repouso na periferia e no centro. As interações da matéria e do espaço determinam o movimento e o repouso dos corpos.'

O autor considera ainda que essa visão incorpora certos "resíduos" de concepções mais primitivas de espaço associadas ao "espaço da vida", segundo as quais as diferentes regiões e direções têm características diferentes. Kuhn cita como exemplo o fato de, em muitas sociedades mais antigas, palavras que denotam direções estarem associadas a partes do corpo, e refletirem as diferenças dessas partes. Cita também a cosmologia egípcia, que designava a região das estrelas circumpolares como sendo a região da "vida eterna". 14

Chegamos com isso a um segundo ponto a ressaltar a respeito da cosmologia aristotélica. Os "resíduos" de concepções primitivas de espaço, como foi exposto acima, relacionam-se a uma visão essencialmente anímica do mundo, onde a distinção entre o "orgânico" e o "inorgânico" deixa de ser clara, e os objetos parecem ser movidos por "desejos" e "motivações" internas. Kuhn, embora saliente que o animismo não é toda a base psicológica da teoria aristotélica do movimento, reforça a idéia de que no universo conceitual desse mundo fechado está presente um componente anímico, que por sua vez é bastante comum nas concepções infantis sobre a natureza. Há diversos estudos em educação que relacionam as visões das crianças sobre o movimento com a teoria

\footnotetext{
${ }^{13}$ KUHN, T. S. - Op. cit., p. 121.
} 
aristotélica, e evidenciam muitas vezes o caráter anímico de ambas. Uma citação um pouco mais longa esclarece-nos esse importante ponto:

"As pedras de Aristóteles não estão vivas, embora o seu universo freqüentemente pareça estar, pelo menos metaforicamente. (...) Mas a sua percepção da pedra a saltar da mão para atingir o seu lugar natural no centro do universo não é assim tão diferente da percepção da criança sobre o balão que gosta do ar ou da caixa que cai porque gosta de estar aí. O vocabulário mudou; os conceitos são manipulados pela lógica dos adultos; o animismo foi transformado. Mas a maior parte da atração da doutrina de Aristóteles deve residir na naturalidade da percepção que apóia a doutrina.

Parece-nos que é nesse "animismo transformado" que se encontra embebido o conceito de tempo em Aristóteles. Embora compartilhando de certas características que estarão presentes no "tempo absoluto" de Newton, como a continuidade e a infinitude, tais semelhanças são apenas aparentes. Sua infinitude não é "atual", mas "potencial", e a continuidade não é, ontologicamente, congruente com a visão newtoniana. Como vimos, o tempo para Aristóteles é apenas o "aspecto numerável do movimento", que adquire algum sentido somente na presença de uma alma que possa "contar". A necessidade dessa "alma" é, certamente, um componente anímico, ainda que a idéia de mensurabilidade, de numeração, resgate também uma certa visão empirista (ou realista ingênua).

Será que tal análise encontra respaldo nas concepções infantis sobre o tempo? As crianças costumam associar o tempo a diversos outros conceitos, mas principalmente com as idéias de "mudança" e "movimento", vinculadas num primeiro momento a fenômenos naturais e meteorológicos. Desse modo, o tempo passa enquanto uma pessoa está em crescimento, por exemplo, mas não a partir do momento em que se torna adulta. Um estudo com crianças de 7 a 11 anos de idade mostrou que as mais novas estabelecem uma conexão entre "tempo físico" e "tempo meteorológico" ou "clima", caminhando aos poucos para um conceito mais abstrato de tempo, independente das ações do sujeito ou de fenômenos percebidos por ele. ${ }^{16}$ Já Piaget, em seus estudos sobre

\footnotetext{
${ }^{14}$ Ibid., p. 119-120. Estrelas circumpolares são aquelas que circulam ao redor dos pólos celestes sem abaixar no horizonte do observador local.

${ }^{15}$ Ibid., p. 119.

${ }^{16}$ PROVERBIO, E. e LAI, S. - Spontaneous models and the formalization of the concepts of weather and time at the elementary school level. International Journal of Science Education, 1989, 11 (1), p. 113-123. $\mathrm{O}$ desenvolvimento da linguagem, afirmam os autores, parece ter seguido um caminho semelhante. A
} 
a noção de tempo em crianças, evidencia mais precisamente como esse conceito encontra-se inicialmente vinculado com o deslocamento ou a velocidade nas análises dos movimentos. Isso ocorre tanto antes quanto depois de estabelecidas as noções de sucessão e simultaneidade de eventos (ou ordem dos acontecimentos) por parte da criança. ${ }^{\square}$ Se, por um lado, alguns aspectos das concepções infantis pareçam corresponder a uma outra espécie de animismo (talvez mais “elementar"), por outro elas compartilham com a visão aristotélica o que lhes falta: um empirismo que meça o tempo de forma inequívoca, ou um realismo que dê a ele uma certa "existência" em si, uma certa "independência" ontológica e epistemológica, ou ainda uma "racionalidade" que o incorpore num quadro conceitual pleno, num conjunto de noções sem "resíduos anímicos". Enfim, que o faça independente de uma "alma" que o "conte", ou de uma "mudança" que confirme sua passagem.

O chamado "tempo psicológico", ou a percepção subjetiva do tempo, parece também corresponder a uma certa dose de animismo, na medida em que associa seu transcorrer a uma percepção pessoal, dependentes de estados internos que variam. É interessante como Newton, nos Principia, irá separar claramente o "tempo absoluto" da mecânica do "tempo relativo", de caráter subjetivista (voltaremos a isso em breve).

Seria importante evocarmos, diante dessa análise, as "doutrinas filosóficas" de Gaston Bachelard, e a idéia de "perfil epistemológico". O conceito de tempo caro à cosmologia aristotélica apresentaria então, sob essa perspectiva, elementos das duas primeiras "doutrinas" consideradas por Bachelard em sua hierarquia: o animismo e o empirismo (ou realismo ingênuo, claro e positivista). Esperamos haver delineado acima aspectos do que poderia ser considerado um "conceito anímico de tempo", ainda que de modo incompleto e simplificado. Embora não tenhamos discutido em pormenores aquilo que corresponderia a uma visão empirista, parece-nos claro que, da mesma forma que para a massa haveria uma "conduta da balança", no caso do tempo seria possível falarmos em uma "conduta do relógio".

Como vimos, seria difícil atribuir um grande peso a tal conceito empirista no paradigma aristotélico, pois não se trata exatamente de medir o tempo, mas de usar a

originária palavra latina tempus mantém um duplo significado em muitas línguas modernas (como o português). Já no inglês, por exemplo, há uma diferenciação: "time" e "weather".

17 PIAGET, J. - Os dados genéticos da epistemologia física. In: PIAGET, J. (org.) - Lógica e Conhecimento Científico (vol. 2), 1981, p. 16-18. 
noção de tempo, que supõe a possibilidade de numeração, como uma medida do movimento. Mas, quando o movimento circular dos céus é apresentado como "uma medida perfeita do tempo", e quando este, contínuo, passa a ser referenciado por aquele, salientam-se aspectos de um empirismo que ainda não representa uma "conduta do relógio", mas que abre caminho para tal. Parece-nos que a importância atribuída ao espaço não permitiu à cosmologia aristotélica estabelecer esse conceito empirista claro do tempo. Embora existissem à época relógios de sol e de água, a sombra do "gnômom" ainda devia-se ao movimento do sol no interior de uma esfera de éter em redor da Terra, e a água das clepsidras ainda gotejava em direção ao seu "lugar natural".

A superação do ponto de vista aristotélico não foi um processo "fácil e tranqüilo", resultado de alguma "experiência crucial" ou simplesmente de novos conhecimentos acrescentados a esse saber. Pelo contrário, a substituição desse paradigma por outro requer uma revolução científica caracterizada, como discutimos no capítulo I, por uma ruptura profunda com o conhecimento estabelecido. Seria ingênuo achar que o paradigma aristotélico-ptolomaico pudesse ser substituído facilmente por outro, ou que alguma simples experiência (como a hipotética experiência realizada por Galileu na torre de Pisa) fosse suficiente para "refutar" tal visão de mundo. Como veremos a seguir, o nascimento da nova mecânica, que teve Copérnico, Galileu, Kepler e Newton como protagonistas, necessitou de uma ruptura com o saber anterior, representada entre outras coisas pela incomensurabilidade entre conceitos anteriores e posteriores à revolução. Pelas palavras de Kuhn:

“(...) a teoria de Aristóteles sobre o movimento é um excelente primeiro passo em direção a uma compreensão do movimento e necessita de uma Terra central estacionária. Os defensores de uma Terra planetária precisarão, no entanto, de uma nova teoria do movimento, e até tal teoria ser inventada, como aconteceu durante a Idade Média, um conhecimento da física terrestre inibirá a imaginação astronômica., 18

Lembremos de passagem que o estabelecimento de "uma nova teoria do movimento", como coloca Kuhn, relaciona-se precisamente com o que P. Feyerabend chama de uma nova "interpretação natural", que implica essencialmente numa nova linguagem de observação, estabelecida a partir de uma re-interpretação dos fenômenos, 
concebidos como aparência mais enunciado. 19 Aliás, Feyerabend aponta que, para o surgimento de uma nova "interpretação natural", pode-se buscar o auxílio de concepções "refutadas" que se complementem, como teria feito Galileu em relação à doutrina copernicana e ao uso do telescópio. É assim também que Kuhn parece relacionar certas concepções que ganharam maior atenção e interesse a partir da revolução copernicana, como a infinitude do espaço ou a existência do vácuo que, embora careçam de sentido num universo aristotélico, podem ser articuladas dentro da nova interpretação que nasce.

O período de "gestação" de uma nova teoria do movimento foi longo. Ptolomeu, que viveu no século II a.C., pode ser considerado uma das últimas grandes figuras da ciência antiga. O saber ocidental decaiu sob o domínio romano e com a ascensão do pensamento cristão. Resgatado posteriormente pelos árabes durante a invasão da península Ibérica no século VII, "ressurgiu" na Europa por volta do século X, quando as primeiras traduções latinas do árabe passaram a ser aceitas. Ao longo de todo esse período, conforme dito no capítulo anterior, o "mundo islâmico" tornou-se um pólo de conhecimento.

Esse processo de recuperação do saber antigo intensifica-se no século XIII, com o surgimento das primeiras universidades, que irão abrigar a tradição filosófica conhecida como escolástica. Kuhn aponta que existiam inúmeros problemas na recuperação dos textos antigos, fazendo com que parecessem, aos olhos dos medievais, contraditórios e desconexos. Consideravam, por exemplo, que Aristóteles e Ptolomeu eram quase contemporâneos, e pertencentes à mesma tradição, quando na verdade o pensamento aristotélico era mais "filosófico" e "cosmológico", enquanto o ptolomaico era mais "matemático". Isso tudo contribuiu para lançar dúvidas sobre toda a tradição.

A Igreja teve um papel determinante nesse processo, uma vez que praticamente concentrou todo o conhecimento durante a Idade Média. Entretanto, sua atitude face ao "saber dos antigos" não foi uniforme ao longo do tempo, o que explica inclusive o declínio e ressurgimento do legado da antigüidade clássica. Os primeiros teólogos

\footnotetext{
${ }^{18}$ KUHN, T. S. - Op. cit., p. 109.

${ }^{19}$ Conforme discutido na seção I.4. de nosso trabalho (p. 31-32).

${ }^{20}$ KUHN, T. S. - Op. cit., p. 112.

${ }^{21}$ Ibid., p. 127-129.
} 
cristãos eram hostis com relação ao conhecimento "pagão", numa época em que a fé cristã procurava afirmar-se. Santo Agostinho (354-430), em particular, representou esse pensamento, muito embora tenha sido influenciado por textos platônicos. ${ }^{22}$ Seria interessante resgatarmos aqui, por um momento, suas colocações sobre o tempo. Como vimos no capítulo precedente, elas surgem no contexto de uma discussão de natureza religiosa: o que estaria fazendo Deus antes da criação? Suas conclusões afastam-no da visão aristotélica, pois afirma que o tempo passou a existir com a criação, e nega que esteja associado ao movimento dos corpos, em particular dos corpos celestes. ${ }^{2.3}$ No entanto, a concepção de Agostinho compartilha com a de Aristóteles um certo “componente anímico", uma vez que a "medida" do tempo é realizada, pelo primeiro, por via de seu espírito, por onde passam as expectativas futuras em direção à memória, enquanto que o segundo, como vimos anteriormente, necessita de uma alma que conte. ${ }^{24}$

Nos séculos XII e XIII, com a hegemonia do cristianismo assegurada, tornaram-se necessárias algumas modificações para fundir a cosmologia aristotélico-ptolomaica com as inconciliáveis teses da Igreja. Desse modo, abandonou-se por exemplo a idéia aristotélica de que o universo e o movimento sempre existiram (em claro confronto com as escrituras), enquanto que a impossibilidade do vazio foi questionada por alguns (limitava o poder infinito de Deus). As esferas homocêntricas num universo geocêntrico adaptaram-se perfeitamente à visão cristã, na qual o ser humano vivia num mundo terreno de corrupções e mudanças, aspirando alcançar a salvação com a elevação de sua alma aos céus eternos e imutáveis. Microcosmo e macrocosmo confundem-se e complementam-se, anjos e arcanjos movimentam os céus. Não é à toa que S. Tomás de Aquino (1225-1274), teólogo que mais contribuiu para a "fusão", defende a existência de três tipos de tempo, como vimos anteriormente: a eternidade "atemporal", o tempo dos anjos, e o dos fenômenos terrestres. Associa o tempo ao movimento, assim como faz Aristóteles, afirmando que o "antes" e o "depois" no movimento é que constituem a

\footnotetext{
${ }^{22}$ Ibid., p. 130.

${ }^{23}$ Conforme apresentado na seção III.2. de nosso trabalho (p. 77).

${ }^{24}$ Seria interessante apontar, de passagem, que a noção de "alma" tem uma importância diferente para platônicos e aristotélicos medievais. Enquanto a filosofia dos primeiros é centrada na alma, onde reside a verdade, a dos últimos considera essa noção como constituinte do ser, tanto quanto o corpo. Para mais detalhes ver KOYRÉ, A. - Aristotelismo e Platonismo na Filosofia da Idade Média. In: KOYRÉ, A. Estudos de História do Pensamento Científico, 1991, p. 22-45.
} 
sucessão temporal. ${ }^{25}$ Compartilha, entretanto, com Santo Agostinho a noção de que o tempo foi criado junto com o universo.

Um importante papel no surgimento da nova teoria do movimento que acabará por aliar-se ao universo heliocêntrico de Copérnico para a derrocada do paradigma aristotélico foi desempenhado, justamente, por críticos escolásticos. Nicolau Oresme, por exemplo, chegou no século XIV a imaginar o movimento hipotético da Terra, apenas para discutir as provas de Aristóteles. Já João Buridan contestou o movimento de projéteis com a sua teoria do ímpeto, que procurou inclusive aplicar ao movimento dos céus. ${ }^{26}$ Ambos poderiam ser considerados, quem sabe, articuladores de um candidato a paradigma. Entretanto, porque os próprios conceitos aristotélicos não podiam ser vistos da mesma maneira na Idade Média e na antigüidade, as críticas escolásticas contribuíram para a crise. O mundo havia mudado e, com ele, as interpretações.

O Renascimento foi o momento propício para a revolução. O impulso dado à astronomia pelas navegações, que exigiam um melhor conhecimento dos céus e uma mais precisa marcação do tempo, e pela necessária reforma do calendário Juliano, uniram-se a diversos fatores de ordem política, econômica e social, para formar o "caldo" que iria alimentar Copérnico, Galileu e Kepler. .7 $^{-}$Além disso, influenciará o pensamento renascentista a corrente neoplatônica, cujas raízes encontram-se nos primeiros séculos da era cristã, e que valorizava a matemática e a geometria, as "formas ideais" de um mundo incorruptível contra a evidência dos sentidos. Kuhn aponta uma ligação entre o neoplatonismo e o culto do sol, este identificado com o Deus neoplatônico, perfeito em sua fecundidade e infinitude. Copérnico e Kepler serão afetados profundamente por essa corrente de pensamento, o que nos faz lembrar as posições de Feyerabend, para quem, em muitos momentos da história da ciência, a razão teria sido "posta em segundo plano", e a adesão às novas idéias seria conseguida por "meios irracionais", incluindo "preconceitos de toda espécie".

\footnotetext{
${ }^{25}$ Conforme apresentado na seção III.2. de nosso trabalho (p. 78-79).

${ }^{26}$ KUHN, T. S. - Op. cit., p. 138-140 e 143-145.

${ }^{27}$ Segundo Koyré, esse período, que acabou por destruir a síntese aristotélica, não corresponde (como dizse muitas vezes) a uma época dotada de "espírito crítico" ou "espírito de ciência". Pelo contrário, trata-se "da época da mais grosseira e mais profunda superstição, da época em que a crença na magia e na feitiçaria se expandiu de modo prodigioso, infinitamente mais do que na Idade Média." Para o historiador, o desenvolvimento da ciência ocorreu à margem do "espírito renascentista", ao qual Kepler encontra-se
} 
É nesse contexto que surge o trabalho de Nicolau Copérnico (1473-1543), de importância capital para o desenvolvimento de uma nova astronomia e cosmologia. Para nós, que temos na questão do tempo nossa preocupação imediata, a obra de Copérnico não trouxe qualquer contribuição direta. Entretanto, indiretamente o seu papel foi crucial, na medida em que abalou todo um sistema explicativo coerente. Uma mudança na astronomia teve que ser acompanhada por uma nova teoria do movimento, e é nesse momento que surgirá a questão temporal, como veremos.

O De Revolutionibus Orbium Caelestium, publicado em 1543, era um livro essencialmente técnico, destinado a astrônomos. Embora tenha propiciado a revolução, não se tratava de uma obra "revolucionária", vinculada que estava à antiga tradição. Copérnico tinha objeções à astronomia de sua época que, segundo ele, era incapaz de resolver o problema dos planetas (ao longo dos séculos que separam Ptolomeu de Copérnico acumularam-se pequenos erros das posições planetárias, gerando uma incongruência maior entre o antigo sistema e as observações). Sob seus "óculos" neoplatônicos o sistema ptolomaico parecia "monstruoso". A mobilidade da Terra representava para ele, a princípio, um artifício matemático útil capaz de minorar as discrepâncias e trazer uma "harmonia" para o modelo do universo. No prefácio de sua obra, após apontar que pensadores da antigüidade haviam sugerido tal idéia, diz Copérnico:

"Tirando vantagem disto, também eu comecei a pensar sobre a mobilidade da Terra; e embora a opinião parecesse absurda, mesmo sabendo agora que outros antes de mim haviam sido livres de imaginar tais círculos como queriam para explicar o fenômeno das estrelas, considerei que também eu podia ser facilmente autorizado a investigar se, presumindo algum movimento da Terra, poderiam ser descobertas explicações mais corretas do que as deles para a revolução das esferas celestes.'

Em muitos aspectos o universo de Copérnico assemelhava-se ao da cosmologia aristotélica. Era esférico, assim como a Terra, e finito. O movimento dos corpos celestes era uniforme, circular e perpétuo, ou composto de movimentos circulares. ${ }^{29}$ Esses movimentos seriam naturais numa esfera, o que permite a Copérnico romper com a

mais ligado do que Galileu. Ver KOYRÉ, A. - A Contribuição Científica da Renascença. In: KOYRÉ, A. Op. cit., p. 46-55.

${ }^{28}$ Apud KUHN, T. S. - Op. cit., p. 168. 
tradição e atribuir, de imediato, um movimento de rotação (em torno do próprio eixo) para nosso planeta, o que explicava a rotação diurna dos astros (de leste para oeste). Como a imobilidade seria mais "nobre e divina" do que a mudança, argumenta o autor que a primeira devia ser imputada aos céus, e não à Terra. Essa, por sua vez, apresentava mais dois movimentos: o de rotação orbital anual em torno do sol, e um movimento cônico anual do eixo. O primeiro desses dois movimentos, aliado a considerações de natureza observacional, como a ausência de uma paralaxe estelar (ver figura 3), que deveria existir no caso de uma Terra "planetária", forçou Copérnico a aumentar em muito (cerca de 75 vezes) o raio da esfera das estrelas, agora fixas. O segundo movimento evidencia mais uma vez a relação de Copérnico com aspectos do pensamento aristotélico, em vias de superação. Porque imagina a Terra fixa numa esfera que gira em torno do sol, precisa supor o movimento cônico do eixo para "compensar" a variação de direção a que ele estaria submetido durante uma rotação anual.

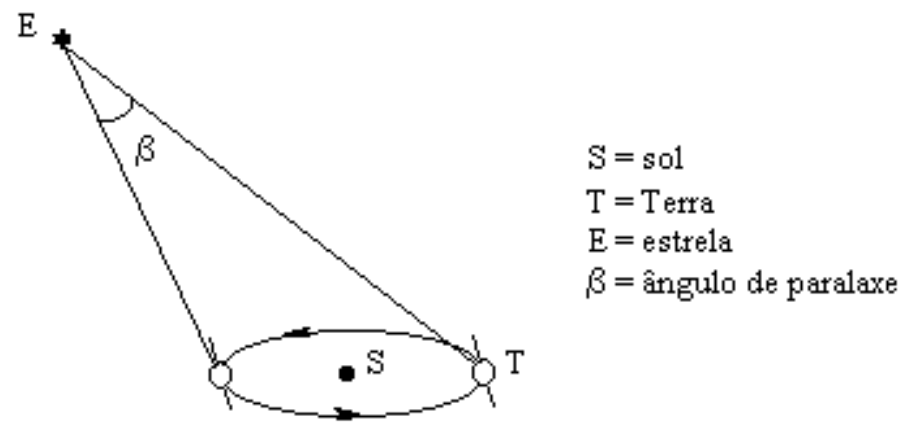

Figura 3: a paralaxe estelar.

Atribuindo a aparência dos movimentos aos céus, mas sua realidade à Terra, o modelo copernicano explicava não apenas a rotação diurna dos astros, mas o movimento (aparente) do sol "para leste", em relação às estrelas, bem como as estações do ano. Entretanto, até aqui o novo universo é equivalente ao anterior, e quem sabe mais complicado. É com relação aos movimentos dos planetas, no entanto, que a explicação copernicana parece mais simples, uma vez que não são necessários epiciclos maiores. $\mathrm{O}$ movimento retrógrado torna-se também um movimento aparente, produzido quando a Terra "ultrapassa" os planetas "exteriores" (Marte, Júpiter e Saturno) ou é

\footnotetext{
${ }^{29}$ Esse aspecto levou Copérnico a negar o equanto, que supõe uma violação desse tipo de movimento. A esse respeito ver KOYRÉ, A. - As Etapas da Cosmologia Científica. In: KOYRÉ, A. - Op. cit., p. 86.
} 
"ultrapassada" pelos "interiores" (Mercúrio e Vênus). Vistos da Terra móvel, os planetas parecem ir e vir em relação ao fundo de estrelas. Qualitativamente, a nova visão é mais econômica que a anterior, mas a previsão quantitativa do novo modelo era tão boa quanto a dos modelos geocêntricos contemporâneos. E, para chegar a tal, Copérnico teve que usar epiciclos menores e excêntricos, inclusive para o movimento da Terra. O seu sistema, como um todo, não é mais simples ou mais exato que o de Ptolomeu. Nas palavras de Kuhn:

"Ambos empregavam mais de trinta círculos; havia pouco que escolher entre eles em economia. Nem os dois sistemas podiam ser distinguidos pela sua exatidão. Quando Copérnico terminou de acrescentar círculos, o seu sistema complicado centrado no sol deu resultados tão exatos como o de Ptolomeu, mas nã deu resultados mais exatos. Copérnico não resolveu o problema dos planetas.

As principais motivações para a adesão ao copernicanismo parecem ter sido de natureza "estética". Além da eliminação dos epiciclos maiores, o novo modelo oferecia uma explicação imediata para o fato de Mercúrio e Vênus aparecerem sempre próximos ao sol, bem como vinculava o tamanho relativo das órbitas planetárias, estabelecendo uma certa "coerência" para todo o sistema. A "harmonia geométrica" ainda era uma promessa no heliocentrismo copernicano, mas foi suficiente para conseguir adeptos dispostos a extrair de sua obra o essencial à construção de um novo universo. Copérnico tornara aguda a crise do paradigma aristotélico-ptolomaico, e fornecera uma fundamentação astronômica suficiente para isso. Entretanto, como um personagem de transição, seu vínculo a antigas concepções não lhe permitiu construir uma "física" compatível com o movimento da Terra. Seus sucessores herdarão novos problemas colocados por sua astronomia, cuja resolução representará o processo de articulação necessário à consolidação da nova cosmologia.

Procurando não nos distanciarmos de nosso propósito, seria importante compreendermos a natureza da oposição a Copérnico. Seu livro passou a ser referência obrigatória para os astrônomos, ainda que alguns se omitissem quanto à tese central. Podia-se inclusive utilizar o sistema matemático de Copérnico e negar-lhe uma "realidade física". Entretanto, a maior oposição veio dos não-astrônomos, e foi crescendo cada vez mais durante o século XVI, acirrando-se no início do século XVII.

\footnotetext{
${ }^{30}$ KUHN, T. S. - Op. cit., p. 198-199.
} 
Mesmo antes da publicação do De Revolutionibus, Lutero contrapôs as idéias de Copérnico à Sagrada Escritura ${ }^{31}$, cuja autoridade máxima será também evocada por Calvino. Uma Terra planetária levantava uma série de problemas (não-triviais) para a vida cristã, como aponta Kuhn:

"Se houvesse outros corpos essencialmente como a Terra, a bondade de Deus necessitaria certamente que eles, também, fossem habitados. Mas se existissem homens noutros planetas, como poderiam eles ser descendentes de Adão e Eva, e como poderiam ter herdado o pecado original, única explicação para q Labuta do homem numa terra feita para ele por uma divindade boa e onipotente?",32

No bojo da luta entre católicos e protestantes inseriu-se o copernicanismo, apanhando dos dois lados. Os últimos, partidários de uma interpretação literal da Bíblia, forneceram uma oposição feroz, mas a estrutura institucional dos primeiros acabou contribuindo para uma atitude mais severa. A Inquisição procurou combater fortemente a doutrina copernicana, não permitindo a impressão de livros que considerassem a Terra móvel, colocando o De Revolutionibus no Índex (1616), impondo a “prisão" e retratação de Galileu (1633), entre outros atos.

Mas, no entanto, a Terra se move! E a cada revolução de nosso planeta tornava-se mais difícil manter a dicotomia celeste-terrestre, própria do aristotelismo. O trabalho de outros, como Kepler e Galileu, irá pavimentar a estrada que leva à nova mecânica. Antes de Kepler, Tycho Brahe (1546-1601) foi o responsável por uma enorme melhoria das observações e um aumento da precisão dos dados astronômicos, que serão herdados por Kepler. Tycho estabeleceu um modelo de "compromisso", que considerava a Terra como corpo central, mas onde os planetas deveriam girar à volta do sol. Era equivalente ao modelo copernicano, mas tinha o mérito de abandonar o uso de "esferas cristalinas", uma vez que a órbita do sol deveria "cruzar" a de Marte. Tycho também contribuiu no sentido de romper com a idéia de imutabilidade dos céus, ao observar vários cometas que, devido à ausência de paralaxe, deveriam deslocar-se além da esfera lunar. Fenômenos como esses "jogavam a favor" do sistema de Copérnico, e evidenciam uma mudança de significado, importância e interpretação. É por aí que podemos vislumbrar o caráter de incomensurabilidade discutido no capítulo I. Os céus não serão mais os

\footnotetext{
${ }^{31}$ É interessante notar como, em seu argumento, o mesmo trecho usado por Santo Agostinho para criticar a visão aristotélica do tempo associado ao movimento é agora utilizado para contradizer Copérnico! Apud KUHN, T. S. - Op. cit., p. 224.
} 
mesmos depois de Copérnico. Como coloca também Feyerabend, isso reflete os "óculos" conceituais com os quais olhamos a natureza.

Uma cisão mais profunda com a cosmovisão geocêntrica coube a Johannes Kepler (1571-1630). Copernicano desde cedo, além de melhorar certos detalhes matemáticos do modelo heliocêntrico, estudará especialmente a órbita de Marte, que continha as maiores irregularidades, chegando à sua famosa lei das órbitas elípticas. Com isso, não apenas substituiu todos os excêntricos e epiciclos da antiga astronomia, como rompeu com a tradição do círculo e do movimento uniforme, uma vez que a velocidade de um planeta deveria variar ao longo de sua órbita, o que é o cerne da segunda lei, conhecida como "lei das áreas". Fortemente influenciado pelo pensamento neoplatônico e pitagórico, Kepler considerava o sol como a causa física dos movimentos dos planetas, que eram empurrados em suas órbitas por raios de uma força motriz (anima motrix), cuja origem era o sol. Buscou uma série de outras "harmonias" matemáticas e geométricas no universo, como por exemplo uma relação entre velocidades orbitais dos planetas e a escala musical, e uma relação das dimensões e do número das órbitas com os cinco "sólidos regulares". Sua terceira lei, que relacionava os diversos planetas entre si por meio de uma relação matemática simples, é um exemplo bem sucedido dessa busca.

Chegamos, finalmente, a Galileu Galilei (1564-1642). No âmbito da astronomia, o cientista italiano trouxe grandiosas contribuições no sentido da articulação do modelo copernicano. Com o uso do telescópio, observou os céus como nunca ninguém havia visto, e relatou a profusão de estrelas da via-láctea, as montanhas da lua, as manchas solares, os satélites de Júpiter e as fases de Vênus. Tudo isso era compatível com a nova cosmologia que surgia, na qual não havia a separação entre o celeste e o terrestre, entre o incorruptível dos astros e a corrupção terrena. Entretanto, o telescópio em si não "provava" o heliocentrismo, e sequer foi reconhecido de imediato como um instrumento válido para observações astronômicas. Sua principal função foi a de popularizar a astronomia copernicana, propagandeá-la.

No entanto, o que nos importa mais nesse momento é o trabalho efetivo de Galileu na construção de uma nova teoria do movimento. Sem ela, a astronomia copernicana tornar-se-ia "frágil". O movimento da Terra trazia questões para a física "terrestre" que claramente estavam em desacordo com a visão aristotélica. À idéia do movimento em

${ }^{32}$ KUHN, T. S. - Op. cit., p. 225. 
direção ao "lugar natural", Galileu contrapôs a relatividade do movimento, inaugurando (como diz Feyerabend) uma nova "interpretação natural", ou seja, uma nova forma de olhar o real, um novo prisma diante dos fenômenos. O espaço da física tradicional era absoluto, mas não no sentido newtoniano, e sim devido à noção absoluta de lugar, de uma hierarquia rígida e fixa dos elementos no universo geocêntrico. Como compreender a queda vertical dos corpos numa Terra planetária?

A idéia de movimento compartilhado, de composição de movimentos, da dependência do movimento em relação ao observador (presente nas "transformações de Galileu”), fundamentarão a nova física. Mas não nos poderemos deter na análise de tal construção repleta de argumentos perspicazes e contundentes, próprios do autor. Voltemo-nos à questão do tempo.

Dá-se o estabelecimento da lei de queda dos corpos na Terceira Jornada (Do Movimento Local) do Discorsi e Dimostrazioni Matematiche intorno a due nuove scienze attenenti alla Mecanica ed ai Movimenti Localli, publicado em 1638. Galileu (pela boca de Salviati) inicia dizendo:

"Vamos expor uma nova ciência a respeito de um tema muito antigo. Não existe na natureza nada anterior ao MOVIMENTO e, com referência a ele, não poucos e pequenos volumes foram escritos pelos filósofos; apesar disso, muitas propriedades dignas de serem conhecidas não foram até o momento nem observadas, nem demonstradas. (...) não foi demonstrado, que eu saiba, que um móvel, que cai a partir do repouso, percorre em tempos iguais espaços que mantêm entre si a mesma proporção que têm os números ímpares sucessivos a partir da unidade."

Segue-se uma definição de movimento uniforme e alguns axiomas e teoremas. Em seguida, Galileu apresenta sua definição de "movimento naturalmente acelerado". É aqui que sua opção pelo tempo explicita-se:

"Finalmente, no estudo do movimento naturalmente acelerado, fomos, por assim dizer, conduzidos pela mão graças à observação das regras seguidas habitualmente pela própria natureza em todas as suas outras manifestações nas quais ela faz uso de meios mais imediatos, mais simples e mais fáceis. (...) Quando, portanto, observo uma pedra que cai de uma certa altura a partir do repouso e que adquire pouco a pouco novos acréscimos de velocidade, por que não posso acreditar que tais acréscimos de velocidade não ocorrem segundo a proporção mais simples e mais óbvia? Se considerarmos atentamente o problema,

${ }^{33}$ GALILEI, G. - Duas Novas Ciências, $2^{\mathrm{a}}$ edição, 1988, p. 153. 
não encontraremos nenhum acréscimo mais simples que aquele que sempre se repete da mesma maneira. $O$ que entenderemos facilmente, se considerarmos a estrita afinidade existente entre o tempo e o movimento: do mesmo modo, com efeito, que a uniformidade do movimento se define e se concebe com base na igualdade dos tempos e dos espaços (...), assim também, mediante uma divisão do tempo em partes iguais, podemos perceber que os aumentos de velocidade acontecem com simplicidade; concebemos no espírito que um movimento é uniforme e, do mesmo modo, continuamente acelerqdp, quando, em tempos iguais quaisquer, adquire aumentos iguais de velocidade.

O modo "mais simples e óbvio" será portanto, para Galileu, aquele no qual acréscimos iguais de velocidade ocorram em tempos iguais. Koyré, entretanto, nos lembra que Galileu nem sempre pensou assim. Em seu manuscrito De Motu, escrito durante o período em que passou em Pisa, ele chegou a defender que a aceleração do movimento de queda ocorria somente no início do movimento, sendo a velocidade final de queda (proporcional ao peso do objeto) atingida a partir de um dado momento, permanecendo constante depois.

Em uma carta posterior a Paolo Sarpi, de 1604, Galileu mostra já conhecer a lei de queda, mas parece buscar uma explicação que relacione a velocidade de queda com a distância percorrida:

"Refletindo nos problemas do movimento, para os quais, a fim de demonstrar os acidentes por mim observados, me faltava um princípio absolutamente indubitável que pudesse estabelecer como axioma, cheguei a uma proposição que parece suficientemente natural e evidente; estando ela suposta, demonstro depois o resto, nomeadamente que os espaços percorridos pelo movimento natural estão na proporção dupla do tempo e que, por conseguinte, os espaços percorridos em tempos iguais são como os números ímpares ab unitate $e$ as outras coisas. $\underline{E} \underline{p}$ princípio é este: que o móvel natural vai aumentando de velocidade na própria proporção em que se afasta do ponto de partida; (...), (36 (grifo nosso)

Como vemos, Galileu estava na "pista" errada! Seu erro, como aponta Koyré, foi, ao instaurar uma nova forma de olhar o fenômeno da queda dos corpos, trazendo definitivamente a matemática para a física, "geometrizar em excesso", tentando atribuir ao espaço aquilo que era válido para o tempo (Descartes incorreu também nesse erro, do qual não se libertou). Mas o seu "princípio" não o permitia deduzir a lei de queda, conhecida por ele. Num trecho posterior dos Discorsi, Sagredo apresenta-nos a antiga

\footnotetext{
${ }^{34}$ Ibid., p. 160.

${ }^{35}$ KOYRÉ, A. - Estudos Galilaicos, 1986, p. 83.

${ }^{36}$ Apud KOYRÉ, A. - Op. cit., p. 107.
} 
proposta de Galileu, relacionando velocidade e espaço, à qual Salviati responde, afirmando ter cometido o mesmo engano durante certo tempo.

Salviati ainda irá combater uma objeção de Simplício que, pensando num grave ascendente, afirma que esse nunca atingirá o repouso, uma vez que há infinitos "graus de lentidão" pelos quais o grave deve passar. Esse problema dos infinitésimos, que nos remete a Zenão, permite a Galileu explicitar-nos sua visão de tempo contínuo, com infinitos instantes:

"Salviati - É isso o que aconteceria, Sr. Simplício, se o móvel se detivesse durante algum tempo em cada grau de velocidade; acontece, porém, que ele simplesmente passa sem demorar mais que um instante. E, visto que em todo intervalo de tempo, por menor que seja, existem infinitos instantes, estes são suficientes para corresponder aos infinitos graus de velocidade que diminui. Que esse grave ascendente não permaneça durante algum intervalo de tempo num mesmo grau de velocidade, fica evidente do seguinte modo: se, fixado um intervalo de tempo determinado, no primeiro instante desse tempo e também no último, se encontrasse que o móvel tem o mesmo grau de velocidade, poderia, a partir desse segundo grau de velocidade, ser igualmente elevado por um espaço semelhante, da mesma maneira que do primeiro foi levado ao segundo e, pela mesma razão, passaria do segundo ao terceiro, para continuar finalmente seu movimento uniforme ao infinito.'

Essa discussão dos "infinitos instantes e graus de velocidades" evidencia como o conceito de infinito, em Galileu, já não representa mais o que representava para Aristóteles. A noção de divisibilidade ao infinito do tempo já não tem o mesmo significado anterior, indicando uma ruptura conceitual. Para Galileu, uma grandeza contínua seria composta por uma infinidade de elementos infinitamente pequenos (os “indivisíveis"), ou seja, o divisível seria composto por indivisíveis.

Retomando brevemente as indagações iniciais de nosso "episódio", diríamos que o "erro" de Galileu mostra a sua dificuldade em romper com uma física essencialmente "espacial", onde o tempo era um mero coadjuvante. As idéias neoplatônicas que o influenciaram também contribuíram para essa "geometrização em excesso". Outros aspectos de seu pensamento evidenciam, como vimos com Koyré, seu vínculo

\footnotetext{
${ }^{37}$ GALILEI, G. - Op. cit., p. 163.

${ }^{38}$ GANDT, F. de - Nascimento e Metamorfose de uma Teoria Matemática: a Geometria dos Indivisíveis na Itália (Galileo, Cavalieri, Torricelli). Cadernos de História e Filosofia da Ciência, 1986, 10, p. 29-37.
} 
(principalmente no início da carreira) com visões aristotélicas. ${ }^{399}$ Galileu foi ainda um personagem de transição entre dois paradigmas, mas certamente muito mais vinculado ao novo saber. A velha tradição gradualmente perdia o seu lugar.

A "temporalização" do movimento de queda insere-se, portanto, na construção de uma teoria do movimento incomensurável com o paradigma anterior. Esse momento marca de forma indelével a introdução do conceito de tempo de modo profundo na mecânica, abrindo o caminho que leva ao tempo absoluto newtoniano.

Apontada a dificuldade, seria lícito perguntar que fatores poderiam ter contribuído para essa análise galileana. Certamente que os trabalhos dos críticos medievais de Aristóteles, como Oresme e Buridan, além de outros importantes autores citados por Koyréte ${ }^{10}$, como J. B. Benedetti, representaram boa parte desses fatores. Seriam os únicos? Com um pouco de cautela, arriscaríamos dizer que não.

Como dissemos no capítulo anterior, os primeiros relógios mecânicos datam do final do século XIII, e parecem ter sido herdeiros de espécies de "calendários mecânicos", ao mesmo tempo destinados a marcar o tempo e simular o movimento dos céus. Ornamentavam as grandes catedrais, inicialmente, e aos poucos passaram a existir relógios públicos. No século XIV surge a ampulheta, e no século XV os relógios de algibeira. A "marcação do tempo" não passava a estar, apenas, mais presente na vida cotidiana, mas também trazia consigo marcas profundas na maneira de encarar o tempo em si. Embora esses relógios mecânicos "primitivos" fossem bastante imprecisos, a idéia de mecanismo levou quase que diretamente ao estabelecimento de metáforas em relação ao cosmos: o universo como um relógio. Whitrow aponta como tal visão já está presente implicitamente em Oresme, no século XIV, e mais explicitamente em Kepler, já no século XVII.

Se as revoluções dos astros assemelhavam-se às de um relógio, esse por sua vez era cada vez mais usado e importante na Terra. Já apontamos em outro momento a sua relevância para as navegações, por exemplo. Whitrow afirma que a imagem típica do tempo no Renascimento era a do destruidor munido de uma foice, e foi aos poucos

\footnotetext{
39 Por exemplo, com relação à lei da inércia, Galileu parece ter chegado a uma espécie de "inércia circular", ou seja, à noção de um movimento circular infinito na ausência de "forças". KOYRÉ, A. - Op. cit., p. 285-286.

${ }^{40}$ KOYRÉ, A. - Op. cit., p. 58-75. Ver também o artigo: Giambattista Benedetti, Crítico de Aristóteles. In: KOYRÉ, A. - Estudos de História do Pensamento Científico, 1991, p. 128-151.

${ }^{41}$ WHITROW, G. J. - O Tempo na História, 1993, p. 140.
} 
sendo substituída por visões mais otimistas (inclusive em relação à história) ao longo do século XVII. 22

A revolução de que trata esse "episódio" é certamente fruto de uma época, e portanto não apenas motivada por fatores "internos" à ciência. Ainda que Galileu não se tenha valido de relógios mecânicos, o desenvolvimento mais propriamente tecnológico dos mesmos, próprio de sua época, alterou a visão comum $e$ científica do tempo, o que pode ter contribuído para a "temporalização" do movimento de queda.

Nos Discorsi, Galileu descreve a sua famosa experiência do plano inclinado, donde deriva a lei $s \propto t^{2}$. Preocupa-se em relatar o mecanismo de medida do tempo através de sua "clepsidra":

"No que diz respeito à medida do tempo, empregávamos um grande recipiente cheio de água, suspenso no alto, o qual, por um pequeno orifício feito no fundo, deixava cair um fino fio de água, que era recolhido num pequeno copo durante todo o tempo em que a bola descia pela canaleta ou por suas partes. As quantidades de água assim recolhidas eram a cada vez pesadas com uma balança muito precisa, sendo as diferenças e proporções entre os pesos correspondentes às diferenças e proporções entre os tempos; e isto com tal precisão que, como afirmei, estas gperações, muitas vezes repetidas, nunca diferiam de maneira significativa.'

A inexatidão inerente às experiências galileanas, manifesta aqui em sua medida do tempo, permite-nos compreender a relutância do autor em atribuir um valor concreto à aceleração dos corpos em queda, segundo Koyré. Galileu parece ter percebido a importância de uma medição mais precisa do tempo, e seus estudos com o pêndulo refletem tal necessidade. Entretanto, ele não utilizou o movimento pendular em suas experiências, e será C. Huygens o responsável não apenas pela construção dos primeiros relógios mecânicos de pêndulo, mas pela determinação correta do valor de $g$.

Aristóteles estabelecera que "o tempo é a medida do movimento". Chegara a hora, então, de medi-lo.

Teria sentido, conseqüentemente, retomarmos o referencial bachelardiano para analisar o conceito de tempo em Galileu. Já não encontramos aqui os "resíduos anímicos" que salientamos estarem presentes no aristotelismo. A clepsidra substitui a

\footnotetext{
${ }^{42}$ Ibid., p. 150-157.

${ }^{43}$ GALILEI, G. - Op. cit., p. 176.

${ }^{44}$ KOYRÉ, A. - Uma Experiência de Medida. In: KOYRÉ, A. - Estudos de História do Pensamento Científico, 1991, p. 271-300.
} 
"alma que conta", instituindo um empirismo claro, e uma "independência conceitual" ao tempo. Podemos agora falar em uma "conduta do relógio" correspondente a um realismo ingênuo. A medição precisa do tempo define o próprio tempo, assim como a balança define a massa. E que interessante simbiose entre as condutas "da balança" e "do relógio" proporciona-nos Galileu, que mede o tempo pesando a água!

Essa noção empirista encontra-se fortemente ligada a aspectos da organização econômica e social, estando cada vez mais presente na vida do cidadão comum ao longo dos séculos. Ainda hoje, é comum pensar-se o tempo como sendo "aquilo que o relógio mede", e o "horário de verão", por exemplo, ainda parece "roubar" efetivamente uma hora na vida de muitos.

Voltando a Galileu, ingênuo seria atribuirmos a ele apenas essa visão. A representação que faz do tempo por meio de uma linha reta geométrica, em vários teoremas e proposições dos Discorsi, abre caminho para o conceito de tempo absoluto de Newton, que procuraremos caracterizar a seguir (dentro ainda de uma análise bachelardiana) como uma visão racionalista do tempo. Entretanto, Galileu não explicita essa visão, não a abstrai inteiramente dos fenômenos, como fará Newton.

A astronomia copernicana abrira a possibilidade de novas especulações sobre o universo. Nos séculos XVI e XVII renascem concepções de um universo infinito, assim como o atomismo ganha a força que perdera com a vitória do pleno aristotélico na antigüidade. Essas idéias misturam-se na cosmologia de René Descartes (1598-1650), que imaginou um mundo constituído de partículas indivisíveis, mas que preenchiam de tal forma o universo que o tornavam um pleno de corpúsculos. Está presente em Descartes a noção de um mecanismo físico que explicasse o movimento circular dos astros, representado pelos "vórtices" de sua cosmologia. Da mesma forma Kepler, que se inspirou no trabalho de W. Gilbert (De Magnete) para supor uma segunda força - de natureza magnética - entre o sol e os planetas, também concebia o universo segundo um mecanismo auto-governado, semelhante a um relógio. 45

\footnotetext{
${ }^{45}$ KUHN, T. S. - Op. cit., p. 270-275 e 277-280. Aliás, quanto às leis de Kepler e a idéia de "relógio", O. Costa de Beauregard afirma: "A segunda lei de Kepler fazia, por definição, de cada planeta um relógio válido para subdividir o tempo de uma das suas revoluções; a terceira lei declarava solidários entre si todos esses relógios, fazendo-os "numerar" um único e mesmo tempo.". BEAUREGARD, O. C. de - A Grandeza Física "Tempo". In: PIAGET, J. (org.) - Lógica e Conhecimento Científico (vol. 2), 1981, p. 114.
} 
Kuhn assinala como o rompimento da dicotomia celeste-terrestre tornara a questão do movimento planetário um problema de "mecânica aplicada". Robert Hooke (16351703) e Isaac Newton (1642-1727), utilizando-se do conceito de inércia de Descartes, darão na mesma época o "salto" fundamental e crucial, afirmando que a lua cai como uma maçã, ou seja, a mesma força gravitacional é a responsável pelos dois movimentos. Coube a Newton o estabelecimento de uma lei matemática para a atração.

É interessante notar como a idéia de gravidade como inata à matéria ia de certo modo de encontro a uma explicação puramente mecânica e corpuscular, parecendo conter elementos da cosmologia de Aristóteles. Newton reconheceu esse fato, e a busca de uma "causa" da gravidade o atormentou durante toda a vida. Talvez esse ponto tenha sido bastante motivador para o auxílio que Newton procurou na alquimia e na filosofia hermética, entre outras influências, como dissemos no capítulo precedente.

Newton inicia o Principia com um conjunto de definições (quantidade de matéria, quantidade de movimento, força centrípeta etc), nas quais já aparece o tempo. No escólio da primeira parte, ele afirma não haver definido certas grandezas (entre elas o tempo) por serem bem conhecidas de todos, mas acrescenta:

"Contudo, observo que o leigo não concebe essas quantidades sob outras noções exceto a partir das relações que elas guardam com os objetos perceptíveis. Daí surgem certos preconceitos, para a remoção dos quais será conveniente distinguilas entre absolutas e relativas, verdadeiras e aparentes, matemáticas e comuns.

I - O tempo absoluto, verdadeiro e matemático, por si mesmo e da sua própria natureza, flui uniformemente sem relação com qualquer coisa externa e é também chamado de duração; o tempo relativo, aparente e comum é alguma medida de duração perceptível e externa (seja ela exata ou não uniforme) que é obtida através do movimento e que é normalmente usada no lugar do tempo verdadeiro, tal como uma hora, um dia, um mês, um ano. 46

Os "preconceitos" a que se refere Newton no início da citação acima representam justamente as dificuldades de abstração de um tal conceito absoluto de tempo a partir da vida comum. São obstáculos, no sentido bachelardiano, como o são a experiência primeira, o animismo, o substancialismo, entre outros. ${ }^{47}$ A concepção newtoniana de tempo absoluto é claramente separada do tempo "relativo, aparente e comum", que é uma medida do primeiro. O tempo absoluto não tem relação com "qualquer coisa

\footnotetext{
${ }^{46}$ NEWTON, I. - Principia: Princípios Matemáticos de Filosofia Natural, 1990, p. 7.

${ }^{47}$ BACHELARD, G. - A Formação do Espírito Científico, 1996.
} 
externa", é uma abstração. Já não há mais espaço, em Newton, para uma "conduta do relógio", no sentido de um conceito empírico de tempo. A separação entre a "medida do tempo" e o "tempo em si" permite-nos caracterizar essa noção como um conceito racionalista de tempo, ainda dentro do referencial epistemológico de Bachelard.

Reiterando sua posição, continua Newton um pouco adiante:

"Tempo absoluto, em astronomia, é distinguido do tempo relativo, pela equação ou correção do tempo aparente. Porque os dias naturais são de fato desiguais, apesar de serem comumente considerados como iguais e usados como uma medida de tempo; os astrônomos corrigem essa desigualdade, para que possam medir os movimentos celestes por um tempo mais rigoroso. Pode ser que não haja algo como movimento uniforme, onde o tempo possa ser rigorosamente medido. Todos os movimentos podem ser acelerados e retardados, mas o fluxo de tempo absoluto não é passível de mudanças. A duração ou perseverança da existência das coisas permanece a mesma, sejam os movimentos rápidos ou lentos, ou até completamente nulos. E, portanto, essa duração deve ser distinguida daquelas que são apenas suas medidas perceptíveis, a partir das quais aquela é deduzida através da equação astronômica. ${ }^{, 48}$

Com o cálculo infinitesimal e a consolidação da nova cosmologia, insere-se o tempo num outro quadro conceitual "completo", fazendo parte de um conjunto de noções que estabelecem um outro vínculo entre a razão e o sensível, superando um realismo imediato.

Não podemos esquecer, no entanto, a relação estabelecida por Newton entre o $d t \mathrm{e}$ a ação de Deus no universo, que gerou duras críticas por parte de seu contemporâneo Leibniz, e para a qual chamamos a atenção em outra oportunidade. Outra importante crítica ao conceito de tempo em Newton deveu-se a E. Mach que, conforme exposto no capítulo III, encarava-o como um “ocioso conceito metafísico". Entretanto, até o advento da teoria da relatividade, a noção newtoniana de tempo reinará, absoluta.

Com o trabalho de Newton podemos dizer que se completa a revolução. O universo aristotélico-ptolomaico fora substituído por outro, que trouxe um conjunto de novos problemas e possibilidades para a ciência, além de haver influenciado diversas outras áreas, tais como a filosofia e a política. Tratava-se de uma nova maneira de olhar a natureza, que rompia radicalmente com os conceitos da antiga cosmologia, colocando a perspectiva de um "universo mecânico", governado por leis matemáticas precisas, e 
funcionando como um relógio. Ainda que o próprio Newton não ratificasse essa noção, surgiria o determinismo matemático e científico como decorrência de sua grandiosa obra.

Ao mundo fechado e à hierarquia de "lugares" sobrepunha-se um mundo infinito, e um espaço homogêneo e isotrópico. Com relação ao conceito de tempo, assistimos também a uma transição entre incomensuráveis: do animismo-empirismo primitivo, que vimos estar presente em Aristóteles, para o racionalismo característico do novo paradigma, ambas as noções imersas em seus respectivos universos conceituais.

${ }^{48}$ NEWTON, I. - Op. cit., p. 8-9. 
Preso à realidade

dos desejos

subtraídos

Vejo o passar do Tempo

Cada grão da ampulheta

É algo que não realizei

Cruzando o funil da História

- Presente - 


\section{FECHAMENTO}

Se a educação, como diz Paulo Freire, visa não apenas inserir o homem no mundo, mas $\underline{c o m}$ o mundo, de uma forma crítica e autônoma, então esse homem deve ser capaz de "ler" esse mundo, cuja linguagem é constituída, em grande parte, de caracteres "científicos". Por isso, saber ciência é poder desvelar o mundo, interpretá-lo, compreendê-lo, questioná-lo, transformá-lo. Nossa cultura é, também e principalmente, uma cultura científica.

Seria o ensino tradicional, da forma como o caracterizamos em nosso trabalho, uma via propícia a esse desvelamento? Contra uma tal educação, pobre e desmotivadora, massificadora e alienante, fundada numa concepção metafísica do conhecimento, cujo ideal é a transmissão pura e simples do saber (apreendido pelo sujeito por um processo semelhante), juntamo-nos a uma legião (e não são poucos!) que parte de outros pressupostos. E não se trata, é claro, de uma luta do "bem" contra o “mal”, mas de um (duro) processo de conservação e transformação cultural, do qual somos agentes e vítimas.

Fundamentado em uma concepção dialética do conhecimento, que o considera mutável, construído e contextualizado historicamente, e que estabelece uma outra relação entre os sujeitos cognoscentes e o objeto cognoscível, encontra-se o ensino libertador e dialógico. Uma concepção de conhecimento científico, cujas raízes são as "epistemologias históricas da ciência", vinculou-se em nosso trabalho à problematização dialógica para estabelecer, dentre outras coisas, a necessidade pedagógica da história da ciência.

Essa "fundamentação teórica" poderia encontrar, no que se refere ao ensino de física, inúmeros temas a abordar. Essa ciência, em sua particular maneira de olhar o real, proporciona-nos um vasto campo de atuação, do qual "retiramos" (por motivações várias) o conceito de tempo.

Para o cidadão comum talvez o tempo seja "aquilo que o relógio marca", ou ainda o "clima". No entanto, o ensino de física pode amplificar esse conceito, re-defini-lo a

partir dos "universos conceituais" nos quais se insere, de suas relações e interfaces com outras noções. Procuramos justamente mostrar através desse trabalho uma possível 
maneira de problematizá-lo, tornando-o objeto de ad-miração, no sentido freireano. A história da ciência e a epistemologia científica vieram em nosso auxílio para re-criar esse conceito. Nosso objetivo com o "exemplar" que elaboramos é, como não poderia deixar de ser, contribuir para a formação do professor de ciências e para sua atuação em sala de aula. Porque o tear necessita de um tecelão.

Finalizando, gostaríamos ainda de assinalar alguns pontos de continuidade de nosso trabalho, especificamente no que se refere à elaboração de outros "episódios", uma vez que o capítulo IV limitou-se a um certo período da história da ciência.

Imaginamos, no mínimo, dois outros "exemplares": o primeiro abarcaria o período compreendido, aproximadamente, entre os finais dos séculos XVII e XIX. Nesse caso tratar-se-ia, essencialmente, do processo de articulação da mecânica newtoniana, aprofundando uma discussão sobre a homogeneidade do tempo (e sua relação com a conservação da energia), e a idéia de "reversibilidade temporal". Surgiria então a termodinâmica e a mecânica estatística, o conceito de entropia (associado à "irreversibilidade temporal") e a noção de probabilidade. Parece-nos que esse "episódio" representaria, numa análise bachelardiana, um "aprofundamento do pensamento racional", quem sabe levando-nos a um conceito de tempo que pudesse ser caracterizado no âmbito do "ultra-racionalismo" ou "racionalismo complexo". Já o segundo "exemplar" completaria essa análise, estabelecendo uma contraposição entre a mecânica clássica e a teoria da relatividade especial, representada pela oposição entre o papel do tempo nas transformações de Galileu e Lorentz. Nesse caso, a idéia de "revolução científica", no sentido kuhniano, voltaria à cena.

E o "ultra-racionalismo dialético" de Bachelard? Estaria essa "doutrina filosófica" já presente, com relação ao conceito de tempo, no escopo do conhecimento físico atual? São conjecturas, rotas que se abrem à reflexão, em virtude do trabalho que se fecha. 


\section{BIBLIOGRAFIA:}

AGOSTINHO, STO. - Confissões (coleção “Os Pensadores”). Trad. J. Oliveira Santos e

A. Ambrósio de Pina, São Paulo, Abril Cultural, 2a edição, 1980.

AURANI, K. - Ensino de Conceitos: Estudo das Origens da $2^{a}$ Lei da Termodinâmica e do Conceito de Entropia a partir do século XVIII (Dissertação de Mestrado IFUSP/FEUSP). São Paulo, 1985.

BACHELARD, G. - A Filosofia do Não - Filosofia do Novo Espírito Científico. Trad. Joaquim José Moura Ramos, Lisboa (Portugal), Presença, 5a edição, 1991.

- O Novo Espírito Científico. Trad. Juvenal Hahne Jr., Rio de Janeiro, Tempo Brasileiro, $2^{\mathrm{a}}$ edição, 1985.

- A Chama de uma Vela. Trad. Glória de Carvalho Lins, Rio de Janeiro, Bertrand Brasil, 1989.

BEAUREGARD, O. C. de - A Grandeza Física “Tempo”. In: PIAGET, J. (org.) -

Lógica e Conhecimento Científico (vol. 2). Porto (Portugal), Livr. Civilização Ed., 1981.

BOCZKO, R. - Conceitos de Astronomia. São Paulo, Edgard Blücher, 1984.

BORGES, J. L. - Borges Oral. Barcelona (Espanha), Bruguera, 2ª edição, 1980.

COVENEY, P. e HIGHFIELD, R. - A Flecha do Tempo. Trad. J. E. Smith Caldas, São Paulo, Siciliano, 1993.

EINSTEIN, A. - Notas Autobiográficas. Trad. Aulyde S. Rodrigues, Rio de Janeiro, Nova Fronteira, $5^{\text {a }}$ edição, 1982.

EISBERG, R. M. e LERNER, L. S. - Física: fundamentos e aplicações (Vol. 2). Trad. Ivan J. Albuquerque, São Paulo, McGraw-Hill, 1982.

FERREIRA, A. B. H. - Novo Dicionário da Língua Portuguesa. São Paulo, Nova Fronteira, 24 impressão, $2^{\mathrm{a}}$ edição, 1986.

FEYERABEND, P. - Contra o Método. Trad. Octanny S. da Mota e Leonidas Hegenberg, Rio de Janeiro, Francisco Alves, 1977.

FREIRE, P. - Extensão ou Comunicação?. Trad. Rosisca D. de Oliveira, Rio de Janeiro, Paz e Terra, $2^{a}$ edição, 1975. 
GALILEI, G. - Duas Novas Ciências. Trad. Letizio Mariconda e Pablo R. Mariconda, Rio de Janeiro: Museu de Astronomia e Ciências Afins; São Paulo: Nova Stella, $2^{\text {a }}$ edição, 1988.

GANDT, F. de - Nascimento e Metamorfose de uma Teoria Matemática: a Geometria dos Indivisíveis na Itália (Galileo, Cavalieri, Torricelli). Cadernos de História e Filosofia da Ciência, 1986, 10, 27-59.

HAWKING, S. W. - Breve História do Tempo. Trad. Ribeiro da Fonseca, Lisboa (Portugal), $4^{\mathrm{a}}$ edição, 1996.

KANT, I. - Crítica da Razão Pura (coleção “Os Pensadores”). Trad. Valério Rohden e Udo Baldur Moosburger, São Paulo, Abril Cultural, 1980.

KOYRÉ, A. - Do Mundo Fechado ao Universo Infinito. Trad. Jorge Pires, Lisboa (Portugal), Gradiva, s/d.

- Estudos Galilaicos. Trad. Nuno F. da Fonseca, Lisboa (Portugal), Publicações Dom Quixote, 1986.

- Aristotelismo e Platonismo na Filosofia da Idade Média; A Contribuição

Científica da Renascença; As Etapas da Cosmologia Científica; Giambattista

Benedetti, Crítico de Aristóteles; Uma Experiência de Medida. In: KOYRÉ, A. Estudos de História do Pensamento Científico. Trad. Márcio Ramalho, Rio de Janeiro, Forense Universitária, 1991.

KUHN, T. S. - A Estrutura das Revoluções Científicas. Trad. Beatriz Vianna Boeira e Nelson Boeira, São Paulo, Perspectiva, 2a edição, 1987.

- A Revolução Copernicana. Trad. Marília C. Fontes, Lisboa (Portugal), Edições 70, 1990.

LALANDE, A. - Vocabulário técnico e crítico da filosofia. Porto (Portugal), Rés, 10a edição, s/d.

LANDAU, L. D. e LIFSHITZ, E. - Física Teórica (Vol. 1). Trad. Edmundo da Silva Braga, Moscou (Rússia), Mir, 1978.

LEIBNIZ, G. W. - Correspondência com Clarke (coleção “Os Pensadores”). Trad. Carlos Lopes de Mattos, São Paulo, Abril Cultural, $2^{a}$ edição, 1983.

LISPECTOR, C. - Para não esquecer. São Paulo, Siciliano, $5^{\text {a }}$ edição, 1992.

LUCRÉCIO - Da Natureza (coleção “Os Pensadores”). Trad. Agostinho da Silva, São Paulo, Abril Cultural, $2^{\mathrm{a}}$ edição, 1980. 
MACH, E. - Desarrollo Historico-Critico de la Mecanica. Trad. Jose Babini, Buenos Aires (Argentina), Espasa - Calpe, 1949.

MARTINS, R. A. - O Universo: teorias sobre sua origem e evolução. São Paulo, Moderna, $2^{a}$ edição, 1994.

MATTOS, C. R. - Entrando na Era do Ensino de Entropia (Dissertação de Mestrado IFUSP). São Paulo, 1991.

MORA, J. F. - Dicionário de Filosofia. Trad. Roberto L. Ferreira e Álvaro Cabral, São Paulo, Martins Fontes, 1994.

NEWTON, I. - Principia: Princípios Matemáticos de Filosofia Natural (Vol.I). Trad. Trieste Ricci et al., São Paulo, Nova Stella; EDUSP, 1990.

NIETZSCHE, F. - O Eterno Retorno (coleção “Os Pensadores”). Trad. Rubens Rodrigues Torres Filho, São Paulo, Abril Cultural, $2^{\mathrm{a}}$ edição, 1978.

NOVELlO, M. - O Círculo do Tempo. Rio de Janeiro, Campus, 1997.

NUSSENZVEIG, H. M. - Curso de física básica (Vol. 1). São Paulo, Edgard Blücher, $2^{\text {a }}$ edição, 1981.

PEDRINACI, E. - La construcción histórica del concepto de tiempo geológico. Enseñanza de las Ciencias, 1993, 11 (3), 315-323.

PESSOA, F. - Mensagem. Rio de Janeiro, Nova Fronteira, $3^{\text {a }}$ edição, 1981.

PESSOA JR., O. - Uma Incerta História do Tempo na Física Quântica. In: ÉVORA, F.

R. R. (org.) - Espaço e Tempo. Campinas, UNICAMP, Centro de Lógica, Epistemologia e História da Ciência, 1995.

PIAGET, J. - Os dados genéticos da epistemologia física. In: PIAGET, J. (org.) - Lógica e Conhecimento Científico (vol. 2). Porto (Portugal), Livr. Civilização Ed., 1981.

PLATÃO - Diálogos (Vol.XI - Timeu - Crítias - O $2^{o}$ Alcibíades - Hípias Menor). Trad. Carlos Alberto Nunes, Belém, Universidade Federal do Pará, 1977.

OS PRÉ-SOCRÁTICOS: FRAGMENTOS, DOXOGRAFIA E COMENTÁRIOS (coleção "Os Pensadores"). Seleção de textos e supervisão de José Cavalcante de Souza; dados biográficos de Remberto Francisco Kuhnen; traduções de José Cavalcante de Souza et al., São Paulo, Abril Cultural, $2^{a}$ edição, 1978.

PRIGOGINE, I. e STENGERS, I. - Entre o Tempo e a Eternidade. Trad. Roberto L. Ferreira, São Paulo, Companhia das Letras, 1992. 
PROVERBIO, E. e LAI, S. - Spontaneous models and the formalization of the concepts of weather and time at the elementary school level. International Journal of Science Education, 1989, 11 (1), 113-123.

QUINTANA, M. - Porta Giratória. São Paulo, Globo, 1988.

RODRIGUES, I. G. - Aspectos Epistemológicos da Mecânica de Newton - Novas Formas de Compreensão dos Conceitos (Dissertação de Mestrado - IFUSP). São Paulo, 1988.

ROSA, J. G. - Grande Sertão: Veredas. Rio de Janeiro, Nova Fronteira, 16 edição, 1984.

ROSS, W. D. - Aristoteles. Trad. Diego F. Pró, Buenos Aires (Argentina), Editorial Sudamericana, 1957.

RUSSELL, B. - História da Filosofia Ocidental, Livro Primeiro. Trad. Breno Silveira, São Paulo, Cia. Editora Nacional, $3^{\text {a }}$ edição, 1969.

SACHS, R. G. - The Physics of Time Reversal. Chicago (EUA), The University of Chicago Press, 1987.

SALINAS, S. R. A. - História da Mecânica Estatística. Cadernos de História e Filosofia da Ciência, 1982, 3, 28-42.

SCHENBERG, M. - Pensando a Física. São Paulo, Nova Stella Editorial, $4^{\mathrm{a}}$ edição, 1990.

SIMÕES, A. A. - A Concepção Dialética do Conhecimento e o Ensino de Física (Dissertação de Mestrado - IFUSP/FEUSP). São Paulo, 1994.

SMOOT, G. e DAVIDSON, K. - Dobras no Tempo. Trad. Maria Ignez D. Estrada, Rio de Janeiro, Rocco, 1995.

SOUZA FILHO, O. M. - Evolução da Idéia de Conservação da Energia - Um Exemplo de História da Ciência no Ensino de Física (Dissertação de Mestrado IFUSP/FEUSP). São Paulo, 1987.

TARSIA, R. D. - O calendário Gregoriano. Revista Brasileira de Ensino de Física, 1995, 17 (1), 50-54.

TOMÁS DE AQUINO, STO. - Compêndio de Teologia (coleção "Os Pensadores"). Trad. Luiz João Baraúna, São Paulo, Abril Cultural, 1973.

VERNE, J. - A Volta ao Mundo em 80 Dias. São Paulo, CODIL, 1970. 
WHITROW, G. J. - O Tempo na História: concepções do tempo da pré-história aos nossos dias.. Trad. Maria Luiza X. de A. Borges, Rio de Janeiro, Jorge Zahar Ed., 1993.

ZANETIC, J. - Física também é Cultura (Tese de Doutoramento - FEUSP). São Paulo, 1989. 